Some Potential Material Supply Constraints in Solar

Systems for Heating and Cooling of Buildings and

\title{
Process Heat
}

(A Preliminary Screening to Identify Critical Materials)

June 1979

Prepared for the U.S. Department of Energy under Contract EY-76-C-06-1830

Pacific Northwest Laboratory Operated for the U.S. Department of Energy by Battelle Memorial Institute 


\title{
NOTICE
}

This report was prepared as an account of work sponsored by the United States Government. Neither the United States nor the Department of Energy, nor any of their employees, nor any of their contractors, subcontractors, or their employees, makes any warranty, express or implied, or assumes any legal liability or responsibility for the accuracy, completeness or usefulness of any information, apparatus, product or process disclosed, or represents that its use would not infringe privately owned rights.

The views, opinions and conclusions contained in this report are those of the contractor and do not necessarily represent those of the United States Government or the United States Department of Energy.

\author{
PACIFIC NORTHWEST LABORATORY \\ operated by \\ BATTELLE \\ for the \\ UNITED STATES DEPARTMENT OF ENERGY \\ Under Contract EY-76-C-06-1830
}

\author{
Printed in the United States of America \\ Available from \\ National Technical Information Service \\ United States Department of Commerce \\ 5285 Port Royal Road \\ Springfield, Virginia 22151
}

Price: Printed Copy s

$\therefore$ Microfiche $\$ 3.00$

-Pages Selling Price

$\begin{array}{ll}001-025 & \$ 4.00 \\ 026-050 & \$ 4.50 \\ 051-075 & \$ 5.25 \\ 076-100 & \$ 6.00 \\ 101-125 & \$ 6.50 \\ 126-150 & \$ 7.25 \\ 151-175 & \$ 8.00 \\ 176-200 & 59.00 \\ 201-225 & \$ 9.25 \\ 226-250 & 59.50 \\ 251-275 & \$ 10.75 \\ 276-300 & \$ 11.00\end{array}$




\section{6}

SOME POTENTIAL MATERIAL SSUPPLY CONSTRAINTS

IN SOLAR SYSTEMS FOR HEATING AND COOLING

OF BUILDINGS AND PROCESS HEAT
(A Preliminary Screening to Identify Critical Materials)
R. L. Watts
W. E. Gurwell
T. A. Nelson
S. A. Smith

June, 1979

Prepared for

the U.S. Department of Energy

under Contract EY-76-C-06-1830

Pacific Northwest Laboratory

Richland, Washington 99352. 


\section{ACKNOWLEDGMENTS}

In the conduct of this study, valuable contributions were made by a large number of people and organizations.

We are especially indebted to the organizations who patiently supplied information necessary to characterize the systems material requirements: Solaron Corporation, Sunworks, American Heliothermal Corporation, KTA Corporation, Ecosol Systems Inc., Clifford S. Nakata Associates, RayPak Inc., the University of Oregon, Lawrence Livermore Laboratory, Chamberlain Manufacturing Corporation and Honeywell Inc.

The following Battelle-Northwest Laboratories personell contributed:

C. H. Bloomster, N. E. Carter, T. B. Correy, D. K. Davis, D. E. Deonigi, R. L. Egeland, C. M. Eliason, T. P. Harrington, J. N. Hartley, J. W. Litchfield, S. D. Rosier, R. P. Smith and J. O. Vining. 


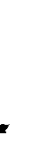

. 
S.I. TO ENGLISH CONVERSIONS

S.I. units are used almost exclusively in this report. Some of the pertinent conversions are:

$\begin{array}{ll}\text { Metric Ton } & 1 \mathrm{MT}=2204.6 \mathrm{lbs} \\ \text { Square lleter } & 1 \mathrm{~m}^{2}=10.764 \mathrm{ft}^{2} \\ \text { Joules } & 1054 \mathrm{~J}=1 \mathrm{Btu} \\ \text { Megajoules } & 1054 \mathrm{MJ}=10^{6} \mathrm{Btu} \\ \text { Gigajoules } & 1.054 \mathrm{GJ}=10^{6} \mathrm{Btu} \\ & 1.054 \times 10^{9} \mathrm{GJ}=10^{15} \mathrm{Btu} \\ & 1 \mathrm{GJ} / \mathrm{m}^{2}-y \mathrm{r}=88,143 \mathrm{Btu} / \mathrm{ft}^{2}-y \mathrm{r}\end{array}$


•

, 


\section{CONTENTS}

SUMMARY OF RESULTS AND RECOMMENDATIONS . . . . . . . . . . . . iX INTRODUCTION $\cdot$. SHACOB AND AIPH DESIGN DESCRIPTIONS

DESIGN DESCRIPTIONS .

REFERENCE DESIGNS METHODOLOGY . . . . . . . . . . . . . 3

CHARACTERIZATION OF REFERENCE DESIGNS . . . . . . . . . 10

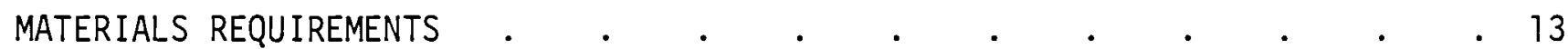

METHODS, MODELS, AND ASSUMPTIONS USED TO IDENTIFY POTENTIAL MATERIALS

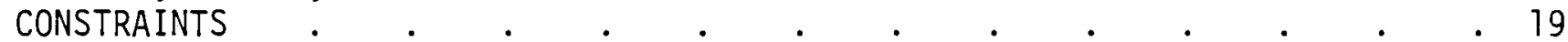

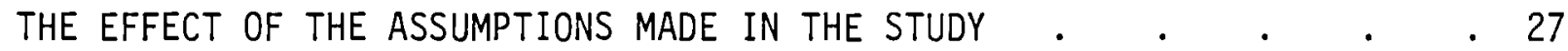

Bulk Material Criteria Threshold Levels . . . . . . . 28

Raw Material Criteria Threshold Levels . . . . . . . 31

RESULTS AND RECOMMENDATIONS • . . . . . . . . . . . 33

"A" MATERIALS IN SHACOB AND AIPH SYSTEMS . . . . . . . 38

Iron, Steel . . . . . . . . . . . . . . 38

Soda Lime Glass and Polyvinyl Fluoride . . . . . . 40

"B" MATERIALS IN SHACOB AND AIPH SYSTEMS . . . . . . . 41

REFERENCES . . .

\begin{tabular}{l} 
APPENDIX A - ACTUAL COMPUTER RUNS OF BULK AND RAW MATERIAL SCREENING \\
FACTORS. \\
\hline
\end{tabular}

APPENDIX B - SOLAR SYSTEMS DESIGN CHARACTERIZATION AND MATERIAL 


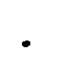

.

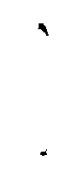




\section{FIGURES}

1. The Materials Cycle . . . . . . . . . . . 19

2. Flow Chart of Materials Assessment Methodology . . . . . . 21

3. Interactive Screening System . . . . . . . . . . 22

4. Assessment of Potential Materials Problems . . . . . . . 23

5. Exponential Growth Curve . . . . . . . . . . 28

\section{$\underline{\text { TABLES }}$}

1. System Designs Characterized . $\quad$. $\quad$. $\quad . \quad$. . . . . . 4

2. Design Variations in Systems Characterized . . . . . . . 5

3. Major Material Uses in SHACOB Systems Characterized . . . . 6

4. Major Material Uses in AIPH Systems Characterized . . . . . . 7

5. Material Categories by Functional Component for SHACOB and AIPH . . 9

6 . Bulk Material Usage in SHACOB Systems . . . . . . . . 14

7. Raw Material Usage in SHACOB Systems . . . . . . . . 15

8. Bulk Material Usage in AIPH Systems . . . . . . . 16

9. Raw Material Usage in AIPH Systems . . . . . . . . 17

10. Bulk Material Threshold Criteria . . . . . . . . . 24

11. Raw Material Threshold Criteria . . . . . . . . . 25

12. Problem Bulk Materials in SHACOB Systems . . . . . . . 34

13. Problem Raw Materials in SHACOB Systems . . . . . . . . . 35

14. Problem Bulk Materials in AIPH Systems . . . . . . . . 36

15. Problem Raw Materials in AIPH Systems . . . . . . . . 37

16. Screening Factors in Scenarios Where "A" Bulk Materials Were Found . 39

17. Some Glazing Material Alternatives . . . . . . . . . 42

18. Criteria Exceeded by "B" Bulk Materials in SHACOB and AIPH Systems . 43

19. Criteria Exceeded by "B: Raw Materials in SHACOB and AIPH Systems . 45 


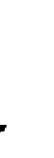

. 


\section{SUMMARY OF RESULTS AND RECOMMENDATIONS}

Nine Solar Heating and Cooling of Buildings (SHACOB) designs and three Agricultural and Industrial Process Heat (AIPH) designs have been studied to identify potential future material constraints to their large scale installation and use.

The nine SHACOB and three AIPH systems were screened and found to be free of serious future material constraints. The screening was carried out for each individual system design assuming 500 million $\mathrm{m}^{2}$ of collector area installed by the year 2000. Also, two mixed design scenarios, containing equal portions of each system design, were screened. The mixed design scenarios assumed 1) $500 \mathrm{M} \mathrm{m}^{2}$ and 2) a billion $\mathrm{m}^{2}$ of collector area installed by the year 2000 .

To keep these scenarios in perspective, note that a billion $\mathrm{m}^{2}$ containing a mixture of the nine SHACOB designs will yield an annual solar contribution of about 1.3 Quads or will displace about 4.2 Quads of fossil fuel used to generate electricity. For AIPH a billion square meters of the mixed designs will yield about 2.8 Quads/year.

Three materials were identified that could possibly restrain the deployment of solar systems in the specific scenarios investigated. They are iron and steel, soda lime glass and polyvinyl fluoride. All three of these materials are bulk materials. No raw material supply constraints were found.

Iron and steel exceeded the threshold for the cost criteria $\left(\$ 15 / \mathrm{m}^{2}\right)$ in two SHACOB systems, in one AIPH system, and in the AIPH mixed design scenarios. A cost of $\$ 15 / \mathrm{m}^{2}$ represents about $5 \%$ of the installed cost of a system. Increases in the price of steel in the future could offset anticipated cost reductions due to learning and mass production and prevent some AIPH and SHACOB systems from becoming economically competitive. If steel prices should rise to an unacceptable level in the future there are several viable alternatives:

1) direct substitution of less expensive materials

2) more efficient use of steel in existing designs

3) redesign of components or functions

4) elimination of certain components, such as storage vessels

5) minimizing the length of pipe and duct runs 
The general strategy for steel should be to minimize steel usage (and therefore price impact) and/or to have substitution alternatives available.

Glass consumption in the billion $\mathrm{m}^{2}$ mixed SHACOB scenario exceeds $10 \%$ of the world consumption in the year 2000 . The required growth rate in glass production of $3 \%$ per year should be easily attainabie. Glass usage in the mixed design SHACOB scenario comes from 7 designs using double glazing, one design using single glazing and one design using evacuated tubes. There are other glazing alternatives, such as fiber reinforced polyester, polyvinyl fluoride (Tedlar*), FEP Teflon*, and polycarbonate from which over 6 billion $m^{2}$ of single glazing could be supplied without exceeding $10 \%$ of the year 2000 world consumption for any of the materials.

Polyvinyl fluoride consumption exceeds $18 \%$ of the world's consumption of fluorocarbons in the year 2000, when used as a single glazing material in 500 million $\mathrm{m}^{2}$ of one system. Meeting this demand would require a growth rate of $8 \%$ per year, which is half that experienced by some other plastics in past ten year spans. Hence, ample production capacity should become available. In the mixed design scenarios, polyvinyl fluoride usage was not a problem since only one of the nine SHACOB systems uses it.

All three potential material problems could be managed by avoiding sudden surges in solar demand and by executing stable long term contracts for their supply.

$\star_{A}$ trademark of E. I. DuPont 


\section{$\underline{\text { INTRODUCTION! }}$}

The objectives of this study are to;

- Identify potential material supply constraints which could seriously impede the large scale future installation of SHACOB and AIPH systems.

- Provide a functional description of materials of construction of typical SHACOB and AIPH systems in computerized format suitable for interactive updating in workshops or future reviews.

- Provide a data base of statistics and production processes in machine accessible format for making this assessment and supporting future SHACOB and AIPH assessments.

- Show the sensitivity of potential shortages to the size of the SHACOB or AIPH implementation scenario.

The scope of the study includes flat plate and concentrating collector systems; generating hot water, hot water and space heating and hot water, space heating, and cooling in residences and public buildings, and in addition includes systems capable of supplying agricultural and industrial process heat.

Many additional systems could be studied, but the scope of systems studied would appear to have provided a reasonable first cut at identifying future potential material constraints. 


\section{SHACOB AND AIPH DESIGN DESCRIPTIONS}

\section{DESIGN DESCRIPTIONS}

The system designs characterized for use in this study, are listed in Table 1 . The designs were selected with the aid of DOE staff to be representative of plausible future systems. The design variations included in the systems characterized are shown in Table 2 .

The material requirements for these systems were determined in detail and entered on the computer data base used in this study. Additional system designs may be added to the data base if desired. Also, design variations on existing systems can be studied by substituting data for a component (e.g., PVC pipe for copper pipe) or a subsystem (e.g., one collector type for another).

Detailed characterizations of each system, including material requirements, are in the Appendix. Some of the major material uses for each system are given in Table 3 for SHACOB systems and Table 4 for AIPH systems. There, the material uses are indicated for the principal parts of the system.

\section{REFERENCE DESIGNS METHODOLOGY}

It is important to draw a distinction between the reference system designs studied in this work and generic system designs. Generic systems are usually not representative of a real system, and may represent an "average" of several selected systems. Generic systems are often used in estimating material requirements for mature technologies, where the implementation scenario is well established and stable. If the technology changes, then the iriplementation scenarios changes, and the generic system no longer represents the "average" system. The complete material count must be done on a redefined generic system. A moreconvenient method of updating material requirements is needed under changing 


\section{TABLE 1. System Designs Characterized}

\section{SHACOB DESIGNS}

Space Heating - Solaron Corporation System using $273 \mathrm{ft}^{2}$ of steel flat plate collectors - air heat transport.

Space Heating and Domestic Hot Water - Solaron Corporation System using $273 \mathrm{ft}^{2}$ of steel flat plate collectors - air heat transport.

Domestic Hot Water - Sunworks copper flate plate collectors $\left(74 \mathrm{ft}^{2}\right)$ - water and ethylene glycol heat transport.

Space Heating and Domestic Hot Water - American Heliothermal Corporation System using $268 \mathrm{ft}^{2}$ of steel flate plate collectors - water and propylene glycol heat transport.

Space Heating and Domestic Hot Water - Ecosol Systems Inc. heat pump system using $258 \mathrm{ft}^{2}$ of KTA Corporation evacuated tube collectors - water heat transport.

Space Heating and Cooling and Domestic Hot Water - Kirtland Air Force Base, Exchange Main store using absorption chillers for cooling and $8320 \mathrm{ft} 2$ of Raypak, Inc., flat plate collectors with aluminum plate and copper tubing water and ethylene glycol heat transport.

Passive Space Heating - Concrete Trombe wall behind $510 \mathrm{ft}^{2}$ of glazing.

Passive Space Heating - Water tank trombe wall behind $510 \mathrm{ft}^{2}$ of glazing.

Passive Space Heating - Direct gain, masonry walls behind $256 \mathrm{ft}^{2}$ of glazing.

\section{AIPH DESIGNS}

Industrial Process Hot water from Solar Ponds - Accelerates chemisal leaching of uranium ore at the Sohio mining and milling complex in Bibo, NM. System design by Lawrence Livermore Laboratory uses $100,000 \mathrm{ft} 2$ of shallow solar ponds - water heat transport.

Industrial Process Heat for Kiln Drying Lumber - Installed on a conventional hardwood drying kiln at the Linden Lumber Company, Linden, AL. System design by Lockheed-Huntsville Research and Engineering Center uses 2,520 $\mathrm{ft}^{2}$ of Chamberlain Manufacturing Corporation steel flat plate collectors - water heat transport.

Process Steam for Drying of Textiles at the Westpoint Pepperell Mill in Fairfax, AL - System design by Honeywe11, Incorporated uses $8,300 \mathrm{ft}^{2}$ of parabolictrough, concentrating collectors - water and steam heat transport. 
TABLE 2. Design Variations in Systems Characterized (Quantity of each type listed)

\begin{tabular}{lcc}
\multicolumn{1}{c}{ Collector } & SHACOB & AIPH \\
\cline { 1 - 1 } Flat Plate & 5 & 1 \\
Evacuated Tube & 1 & \\
Parabolic Trough & & 1 \\
Solar Pond & & 1
\end{tabular}

Passive

Heat Transfer

Air

2

Liquid

43

Application

Residential

Commercial

Process Heat

3

Energy Use

Direct

7

3

Heat Pump

1

Absorption Chiller 
TABLE 3. Major Material Uses in SHACOB System Characterized

\begin{tabular}{|c|c|c|c|c|}
\hline Sys tem & Collector & Pipe, Pumps, Valves & Storage & Heat Exchangers \\
\hline Solaron-H & $\begin{array}{l}\text { Glass } \\
\text { C. Steel }\end{array}$ & C. Steel & Rock & \\
\hline Solaron-H and HW & $\begin{array}{l}\text { Glass } \\
\text { C. Steel }\end{array}$ & C. Stee 1 & $\begin{array}{l}\text { Rock } \\
\text { C. Steel }\end{array}$ & Copper \\
\hline KTA and Ecosol-H and HW & $\begin{array}{l}\text { Copper } \\
\text { Aluminum }\end{array}$ & $\begin{array}{l}\text { Copper } \\
\text { Brass }\end{array}$ & $\begin{array}{l}\text { C. Steel } 1 \\
\text { Concrete }\end{array}$ & $\begin{array}{l}\text { C. Stee } 1 \\
\text { Copper }\end{array}$ \\
\hline $\begin{array}{l}\text { American Heliothermal } \\
\mathrm{H} \text { and } \mathrm{HW}\end{array}$ & $\begin{array}{l}\text { Giass } \\
\text { C. Steel }\end{array}$ & $\begin{array}{l}\text { C. Steel } \\
\text { Prop. Glycol }\end{array}$ & $\begin{array}{l}\text { C. Steel } \\
\text { Giass Wool }\end{array}$ & $\begin{array}{l}\text { Aluminum } \\
\text { Copper }\end{array}$ \\
\hline Sunworks HW & $\begin{array}{l}\text { Copper } \\
\text { Aluminum } \\
\text { Glass Wool }\end{array}$ & $\begin{array}{l}\text { Copper } \\
\text { Ethylene } \\
\text { Glycol }\end{array}$ & $\begin{array}{l}\text { C. Steel } \\
\text { Concrete } \\
\text { Glass Wool }\end{array}$ & Copper \\
\hline $\begin{array}{l}\text { Kirtland AFB-BX } \\
H, C \text {, and HW } \\
\text { (non-residential) }\end{array}$ & $\begin{array}{l}\text { Glass } \\
\text { C. Stee } 1 \\
\text { Copper }\end{array}$ & $\begin{array}{l}\text { C. Steel } \\
\text { Giass Wool } \\
\text { Ethylene } \\
\text { Glycol } \\
\text { Concrete }\end{array}$ & $\begin{array}{l}\text { C. Steel } \\
\text { Asphalt }\end{array}$ & $\begin{array}{l}\text { C. Steel } \\
\text { Copper }\end{array}$ \\
\hline Passive - Direct Gain & $\begin{array}{l}\text { Concrete } \\
\text { Glass } \\
\text { C. Stee } 1\end{array}$ & & & \\
\hline Passive - Trombe Wall & $\begin{array}{l}\text { Concrete } \\
\text { Glass } \\
\text { C. Steel }\end{array}$ & & & \\
\hline Passive - Water Wall & $\begin{array}{l}\text { Concrete } \\
\text { Glass } \\
\text { C. Steel }\end{array}$ & & & \\
\hline
\end{tabular}

\footnotetext{
Abbreviations: $H=$ Space Heating

$H W=$ Domestic Hot Water

$C=$ Space Cooling

c. Steel $=$ Carbon (mild) stee 1

Glass $=$ Soda-lime sheet gláss
} 
TABLE 4. Major Material Uses in AIPH Systems Characterized

\begin{tabular}{|c|c|c|c|c|}
\hline Sys tem & Energy Collection & Energy Transport & Energy Storage & Heat Exchangers \\
\hline LMSC-Lumber Kiln & $\begin{array}{l}\text { Carbon Steel } \\
\text { Softwood } \\
\text { Glass } \\
\text { Glass Wool }\end{array}$ & $\begin{array}{l}\text { Ethylene Glycol } \\
\text { Urethane } \\
\text { Copper } \\
\text { PVC }\end{array}$ & Carbon Steel & Carbon Steel \\
\hline LLL-Solar Pond & $\begin{array}{l}\text { Concrete } \\
\text { Sand } \\
\text { Carbon Steel } \\
\text { Foam Glass } \\
\text { FRP Polyester }\end{array}$ & $\begin{array}{l}\text { Transite } \\
\text { Cast Iron } \\
\text { Concrete }\end{array}$ & $\begin{array}{l}\text { Sand } \\
\text { Carbon Stee1 } \\
\text { Urethane }\end{array}$ & \\
\hline Honeywel 1-Textile & $\begin{array}{l}\text { Carbon Stee } \\
\text { Aluminum } \\
\text { Copper } \\
\text { Pitch }\end{array}$ & $\begin{array}{l}\text { Carbon Steel } \\
\text { Glass Wool } \\
\text { Cast Iron } \\
\text { Aluminum } \\
\text { Neoprene }\end{array}$ & & $\begin{array}{l}\text { Carbon Steel } \\
\text { Copper- } \\
\text { Nicke1, 10\% } \\
\text { Glass Wool }\end{array}$ \\
\hline
\end{tabular}


technology and scenarios, as is the case with solar energy. The reference system methodology facilitates updating.

For SHACOB and AIPH, a number of reference systems were established. They are real systems, with references to engineering drawings and specifications and with known performance. System components are compatible in size, performance, cost, corrosion resistance, etc. Where possible, actual system installations were selected as reference systems. A detailed list of material requirements was established for each system.

Total material requirements for any solar scenario can then be obtained simply be selecting the energy contribution by each technology and the mix of system designs for each technology.

SHACOB and AIPH designs were selected to cover the range of plausible future systems. Not all systems variations were included. Additional designs can be added in the future without disturbing the material requirements for the existing designs in the data base. They will merely supplement previous data already in place.

Most solar system designs will never wholly be replaced; but they will be modified, evolving as improvements are made in performance and cost. These improvements are likely to come at the component level. Updating of material requirements will be facilitated by having materials systematically accounted for, component by component, as is illustrated in Table 5. Fach component is identified separately, according to general function. As components are significantly altered or eliminated by design, the data bank can be updated by simply removing the data for the old component and entering data for the new component. Hence, the effects of gradual changes of design on materials requirements can be monitored continuously with little effort. 
In a similar manner, variations in a system design can be studied by substituting individual components (e.g., plastic pipe for copper pipe) or by subtituting complete subsystems (e.g., one collector type for another).

TABLE 5. Materials Categories by Functional Component for SHACOB and AIPH

12. (a) Energy Collector

12.01 Miscellaneous

12.02 Glazing

12.03 Absorber

12.04 Energy Transport

12.05 Insulation

12.06 Reflector, Concentrator

12.07 Frame

12.08 Seals

12.09 Supports

13. Energy Transport

13.01 Miscellaneous

13.02 Pipe, Wire, or Duct

13.03 Insulation

13.04 Transport Fluid

13.05 Supports

13.06 Sealants

13.07 Valves and Dampers

13.08 Pumps and Fans

13.09 Site Dependent

13.10 Expansion Tanks
14. Energy Conversion

14.01 Miscellaneous

14.02 Heat Exchangers

14.03 Supports

14.04 Absorption Chiller

14.05 Steam Generator

15. Energy Storage

15.01 Miscellaneous

15.02 Primary Storage

15.03 Secondary Storage

15.04 Supports

17. Energy System Controller

17.01 Miscellaneous

17.02 Meters, Switches, Terminal Boards

17.03 Supports

22. Plant Utilities

(a) The numbering system here is taken from a larger list of functional components for solar technology. Numbers not appearing in this table represent functions that apply to solar technologies other than SHACOB and AIPH. 


\section{CHARACTERIZATION OF REFERENCE DESIGNS}

Detailed characterizations of the reference SHACOB and AIPH designs are in Appendix B. Those characterizations are based upon either design documents and drawings (all three AIPH systems and the lone commercial size SHACOB system, Space Heating and Cooling and Domestic Hot Water - Ray Pak Collector, at Kirtland AFB) or published papers and rules of thumb for passive space heating, or manufacturers 1 iterature and drawings (a 11 other SHACOB systems). For each system, a "component takeoff" was done first. Then each component was broken down into its materials of construction using drawings and bills of material from the component designer or manufacturer. In cases where drawings and bills of material were not available, schematics, component descriptions, sales literature, and verbal contact with the manufacturer subsituted adequately for detailed design drawings. Accuracy of material quantities is generally within $10 \%$. Exact engineering materials or alloys of construction are listed where available.

The engineering alloys are converted within the computer program into their bulk material components using a transformation matrix which contains the actual alloy composition. For example, $60-40$ solder is composed of $63 \%$ tin and $37 \%$ lead.

Solar energy implementations scenarios are often expressed in terms of yearly energy contribution for certain years rather than in square meters of collector installed. For purposes of comparison, it was necessary to develop estimates of the yearly energy contribution for each system design. Energy contribution calculations were taken from the design documents for all three AIPH systems and the commercial size SHACOB system, Space Heating and Cooling 
and Domestic Hot Water - Ray Pak Collector, at Kirtland AFB. For all the remaining active SHACOB systems, "f"- chart $(1,2,3,4)$ was used. Computer simulations published by Balcomb et. al. (5) were used to make estimates for the passive systems.

Location is an important factor in energy contribution. All three AIPH systems and the lone commercial size SHACOB system had been designed for specific locations.

Locations for the residential size SHACOB installations were based upon data given by Roach et al., (6) for the economic feasibility of SHACOB systems and the expected number of new houses through 1985. It was assumed that the solar installation rate was proportional to the number of new houses in states where solar was economically competitive without government sponsored incentives. The solar installation rate was used to weight the energy contribution from a solar heating system in the location where the SHACOB system is feasible. Hence, a weighted average yearly solar contribution was arrived at. For residential space heating and hot water, a Washington, DC location yields yearly energy contribution equal to the weighted average solar contribution. For residential hot water, the weighted average solar contribution is met by locating the system in Manhattan, Kansas. Details of the energy contribution calculations are given in Appendix $B$. 


\section{MATERIALS REQUIREMENTS}

The utilization of solar energy will require large quantities of materials. Tables $6,7,8$ and 9 list the bulk materials and raw materials required to construct systems totaling 500 million square meters collector area. Material requirements are listed for 500 miliion square meters of each system design, as we 11 as for 500 million square meters composed of equal portions of each system.

The raw material requirements 1 isted are those required to produce the bulk material requirements listed.

In terms of sheer quantities, the largest material requirements are for iron and steel, aluminum, copper, copper ore, soda lime glass, sand and gravel, Tumber, and water. Those are also the most universally used materials in solar systems. Conversely, other materials are used in only one or two systems, and there are many examples that can be observed by scanning the tables.

The magnitude of use of a material is not important in itself. However, the relationship of material use to availability is important along with a host of other factors such as: cost, import pattern, production growth rate required to meet solar demand, and the extent of known reserves and resources. The object of this report is to address these factors and to access their influence on the orderly and timely construction of solar energy systems to meet our national energy goals.

The following sections discuss the specific approach used in addressing those questions and the results of the study. 
TABLE 6. Raw Material Requirements in Thousand Tons

for SHACOB Systems at $500 \mathrm{Mi} 11$ ion Square Meters.

Individual systems at $500 \mathrm{~m}$. sq. $\mathrm{m}$. and Mixed

System Scenario--A11 9 Systems at $55.6 \mathrm{~m}$. sq. m. each, Totaling $500 \mathrm{~m}$. sq. $\mathrm{m}$.

\begin{tabular}{|c|c|c|c|c|c|c|c|c|c|c|}
\hline Materials & Raypak & KTA \& Ecosol & Solaron R-HT & $\begin{array}{c}\text { Solaron } \\
\text { R-HT \& HW }\end{array}$ & $\begin{array}{l}\text { American } \\
\text { Helio } \\
\end{array}$ & Sunworks & $\begin{array}{l}\text { Trombe } \mathrm{W} . \\
\text { Concrete }\end{array}$ & $\begin{array}{c}\text { Trombe } W . \\
\text { Water }\end{array}$ & $\begin{array}{l}\text { Direct } \\
\text { Ga.n h. }\end{array}$ & $\begin{array}{r}500 \text { Million } M^{2} \\
\text { Mixed Scenarios } \\
\end{array}$ \\
\hline Antimony ore & & & & & & 184 & & & & 20 \\
\hline Asbestos & 57 & & 1 & 1 & & & & & & 7 \\
\hline Bauxite & 8,372 & 24,864 & 1,002 & 1,228 & 5,648 & 23,554 & 7,739 & 7,775 & 7,760 & 9,779 \\
\hline Borate & 321 & & 571 & 591 & 381 & 270 & & & & 237 \\
\hline Butane & 160 & 9 & 140 & 149 & 3 & 70 & & & & 59 \\
\hline Chromite & 28 & & & 11 & & 43 & & 84 & 17,981 & 19 \\
\hline Clays & 614 & 943 & 179 & 198 & 356 & 192 & 8,882 & 1,012 & & 3.376 \\
\hline Coal & 66,344 & 30,780 & 23,722 & 25,555 & 42,289 & 17,658 & 18,176 & 29,295 & 25,861 & 31,100 \\
\hline Coal Bit/Lig & 12,328 & 379 & 18 & 18 & 43,718 & 47,250 & 18,228 & 18,342 & 18,585 & 17,666 \\
\hline Copper ore & 783,155 & 911,905 & 26,186 & 126,301 & 84,593 & $1.149,795$ & & & & 342,711 \\
\hline Feldspar & 82 & 58 & 1,022 & 1,023 & 536 & 9 & 726 & 726 & 727 & 628 \\
\hline Fluorospar & 522 & 776 & 135 & 150 & 371 & 378 & 151 & 266 & 166 & 325 \\
\hline Gyps um & 56 & 248 & & & & 35 & 2,921 & 265 & 5,927 & 1,051 \\
\hline Iron ore & 296.553 & 100,212 & 95,332 & 104,011 & 189,549 & 39,807 & 31,554 & 112,843 & 41,545 & 112,468 \\
\hline Lead ore & 469 & 1,047 & 1,354 & 1,813 & 16 & 781 & & & & 609 \\
\hline Lithium ore & 3,659 & & & & & & & & & 407 \\
\hline Manganese ore & 1,700 & 543 & 619 & 663 & 1,130 & 171 & 183 & 656 & 240 & 657 \\
\hline Mercury & 9 & & & & & & & & & 1 \\
\hline Natural gas & 2,917 & 2,818 & 482 & 736 & 786 & 2,913 & 4,089 & 659 & 8,235 & 2,628 \\
\hline Nickel ore & 395 & & & 142 & & 980 & & & & 169 \\
\hline$N_{2}$ fixed & & & & & & & & & & 0 \\
\hline $\mathrm{O}_{2}$ & 36 & & 16 & 22 & 286 & & & & & 38 \\
\hline Petroleum & 5,113 & 1,869 & 606 & 665 & 4,344 & 3,456 & 370 & $92 i$ & 430 & 1.976 \\
\hline Salt & 13,889 & 16,538 & 9,443 & 9,582 & 8,343 & 15,966 & 10,477 & 10,704 & 10,493 & 11,724 \\
\hline Sand \& gravel & 7,249 & 11,442 & 130,505 & 130,570 & 4,822 & 2,310 & 134,664 & 16,903 & 267,967 & 78,555 \\
\hline Sodium Nitrate & & & 5 & 5 & & & & & & 1 \\
\hline Stone & 739 & 21,024 & & & & 2,969 & 247,756 & 22,460 & 502,740 & 88,703 \\
\hline Sul fur & 443 & 1,430 & 48 & 61 & 285 & 1,178 & 382 & 395 & 383 & 512 \\
\hline Tin ore & 251,298 & 359,454 & & 137,900 & & 608,930 & & & & 150,963 \\
\hline Zinc ore & 8,352 & 3,305 & 24,956 & 24,958 & 12,124 & 202 & & & & 8,217 \\
\hline Cotton & 7 & & & & & & & & & 1 \\
\hline Flax seed & & 153 & & & & & 171 & 171 & & 55 \\
\hline Itilk byprod & & 2 & 1 & 1 & & 5 & & & & 1 \\
\hline Lumber & 1,955 & 2 & 6,832 & 6,832 & 424 & 3,810 & 1 & 2 & 1 & 2,208 \\
\hline Sea water & $1,557,522$ & 4,610 & 41 & 55 & & 24 & & & & 173,723 \\
\hline Soybean & 78 & & & & & & 87 & 87 & & 28 \\
\hline Tungnuts & & 104 & & & & & 116 & 116 & & 37 \\
\hline Water & 165,668 & 108,898 & 148,839 & 151,166 & 74,583 & 140,000 & 3,863 & 78,844 & 6,557 & 97,680 \\
\hline Wheat & & & 21 & 21 & & & & & & 5 \\
\hline Misc & 1,617 & 1,406 & 609 & 753 & 619 & 1,562 & 51 & 181 & 67 & 763 \\
\hline Steam & 103,499 & 140,354 & 27,221 & 30,070 & 66,104 & 123,678 & 44,890 & 61,356 & 47,019 & 71,634 \\
\hline Limestone & 42,072 & 29,414 & 19,337 & 20,332 & 28,394 & 17,604 & 95,983 & & 182,696 & 51,586 \\
\hline Coal Byprod & 200,316 & 496,328 & 40,120 & 41,523 & 1,797 & 482,020 & 312,894 & & & 209,934 \\
\hline Electricity & $5,165,978$ & $1,048,171$ & 181,317 & 188,488 & 973,557 & $2,355,017$ & & & & $1,107,392$ \\
\hline Coal byprod 2 & 169,155 & 182,679 & & & & 377,104 & & & & 81,058 \\
\hline Petroleum byprod & 69,080 & & & & & & & & & 7,682 \\
\hline $\mathrm{TOTAL}^{(\mathrm{a})}$ & $\overline{3,339,309}$ & 919,244 & 244 & 583 & 704 & $\longdiv { 0 5 , 7 8 4 }$ & 460 & 364,063 & 145,380 & $1,262,327$ \\
\hline
\end{tabular}

a. Not including byproduct and electricity. 
TABLE 7. Bulk Material Requirements in Metric Tons for SHACOB

Systems at 500 Mi 11 ion Square Meters. Individua 7

Systems at $500 \mathrm{~m}$. sq. m. and Mixed Systems Scenario--

A11 9 Systems at $55.6 \mathrm{~m}$. sq. m. Each, Totaling $500 \mathrm{~m}$. sq. m.

\begin{tabular}{|c|c|c|c|c|c|c|c|c|c|c|}
\hline Materials & Raypak & KTA \& Ecosol & Solaran $R-H T$ & $\begin{array}{l}\text { Solaron } \\
\text { R-HT \& Hiw } \\
\end{array}$ & $\begin{array}{l}\text { American } \\
\text { Helio }\end{array}$ & Sunworks & $\begin{array}{l}\text { Trombe W. } \\
\text { Concrete }\end{array}$ & $\begin{array}{l}\text { Trombe } k . \\
\text { Water } \\
\end{array}$ & $\begin{array}{l}\text { Direct } \\
\text { Gain W. }\end{array}$ & $\begin{array}{r}500 \text { Million } M^{2} \\
\text { Mixed Scenarios }\end{array}$ \\
\hline Aluminum & $1,525,102$ & $4,914,794$ & & 37,430 & 974,850 & $4,571,000$ & $1,529,750$ & $1,529,750$ & $1,533,000$ & $1,847,663$ \\
\hline Antimony & & & & & & 1,750 & & & & 195 \\
\hline Asbes tos & 56,276 & & & & & & & & & 6,258 \\
\hline Bromine & 97,330 & & & & & & & & & 10,823 \\
\hline Cadmium & 4,575 & & & & & & & & & 502 \\
\hline Carbon black & & 129,270 & & & & & 143,902 & 143,902 & & 46,379 \\
\hline Cement & 350,332 & $5,163,711$ & & & & 729,120 & $60,852,404$ & $5,516,594$ & $123,480,000$ & $21,805,448$ \\
\hline Chromium & 116 & & & & & 7,000 & & & & 791 \\
\hline Copper & $3,550,798$ & $4,145,022$ & 115,245 & 570,315 & 384,513 & $5,225,500$ & & & & $1,555,843$ \\
\hline Glass, Fiber & $1,283,500$ & & $2,285,200$ & $2,364,000$ & $1,525,590$ & $1,078,000$ & & & & 949,241 \\
\hline Glass, Sodalim & $8,836,500$ & 625,500 & $10,578,900$ & $10,578,900$ & $5,762,671$ & $7,983,000$ & $7,807,000$ & $7,807,000$ & $7,812,000$ & $6,661,600$ \\
\hline Gypsum & 28,122 & & & & & & & & & 3,127 \\
\hline Iron \& Stee I & $51,070,088$ & $16,116,000$ & $16,783,560$ & $18,132,746$ & $33,379,590$ & $5,004,622$ & $5,524,394$ & $19,966,678$ & $7,230,754$ & $19,260,778$ \\
\hline Lead & 14,085 & 31,442 & & 13,790 & & 23,457 & & & & 9,204 \\
\hline Lithium & 8,450 & & & & & & & & & 940 \\
\hline Magnes ium & & 6,349 & & & & & & & & 706 \\
\hline Ferromanganese & 307,879 & 97,586 & 101,309 & 109,453 & 201,486 & 31,178 & 33,346 & 120,523 & 43,646 & 116,361 \\
\hline Mercury & 323 & & & & & & & & & 36 \\
\hline Mickel & 453 & & & & & 7,000 & & & & 829 \\
\hline Sand, Gravel & 375,971 & $10,696,259$ & $122,140,008$ & $122,140,008$ & & $1,510,320$ & $126,051,400$ & $11,427,231$ & $255,789,000$ & $72,293,480$ \\
\hline Stone & 783,977 & $21,023,682$ & & & & $2,968,560$ & $247,756,208$ & $22,460,422$ & $502,740,000$ & $88,702,888$ \\
\hline Silicon & 5,899 & 7,172 & & & & 11,200 & & & & 2,699 \\
\hline Silver & 194 & 6,255 & & & & & & & & 717 \\
\hline$T$ in & 25,130 & 35,945 & & 13,790 & & 60,893 & & & & 15,096 \\
\hline Water & $100,098,832$ & $79,480,200$ & & & $59,325,152$ & $21,511,000$ & & $76,065,504$ & & $37,416,652$ \\
\hline $\operatorname{Iinc}$ & 418,383 & 184,106 & $1,401,852$ & $1,401,852$ & 681,149 & 11,200 & & & & 455,758 \\
\hline Stainless Steel & 43,667 & & & 17,730 & & 35,000 & & & & 10,719 \\
\hline Alkyd resin & & 27,105 & & & & & 30.173 & 30,173 & & 9,725 \\
\hline Glue & & & 73,284 & 73,284 & & & & & & 16,298 \\
\hline Lumber & $1,773,105$ & & $6,829,597$ & $6,829,597$ & 420,090 & $3,808,000$ & & & & $2,186,235$ \\
\hline Phenolic Resin & 9,353 & 47,955 & 9,850 & 9,850 & & 161,000 & & & & 26,466 \\
\hline PVC Plastic & 225,105 & & & & & & & & & 25,032 \\
\hline Rubber & 144,480 & & 126,080 & 133,960 & & 63,000 & & & & 51,988 \\
\hline Silicones & 299,925 & & 126,080 & 126,080 & & 28,000 & & & & 64,505 \\
\hline Teflon & 3,806 & & & & 20,100 & 2,100 & & & & 2,890 \\
\hline Hyion & & 10,425 & & & 4,020 & & & & & 1,606 \\
\hline Cotton Fibers & 6,547 & & & & & & & & & 728 \\
\hline Kraft Fibers & 2,806 & & & & & & & & & 312 \\
\hline Urethane & 285,735 & 308,580 & & & & 637,000 & & & & 136,922 \\
\hline Asphalt & $1,354,500$ & & & & & & & & & 150,620 \\
\hline Neoprene & 47,537 & & & & 291,450 & 315,000 & 119,215 & 119,215 & 123,900 & 113,014 \\
\hline Ethylene glycol & $1,457,700$ & & & & & 763,000 & & & & 246,942 \\
\hline Poiye thylene & 4,386 & & & & & & & & & 488 \\
\hline Polyvanyl Fluor. & & 75,060 & & & & & & & & 8,347 \\
\hline EPDO Rubber & 26,768 & & & & & & & & & 2,977 \\
\hline Paint thinner & & 52,125 & & & & & 58,025 & 58,025 & & 18,701 \\
\hline NA Dichrom. & & & & & & & & 75,960 & & 8,447 \\
\hline Polycarbonate & & & 27,580 & 37,430 & 10,050 & & & & & 8,347 \\
\hline Proplyene gly. & & & & & $1,039,170$ & & & & & 115,556 \\
\hline Vitreous Enamel & & & 171.390 & 171,390 & 2,010 & & & & & 38,341 \\
\hline TOTAL & $174,482,725$ & $143,184,543$ & $160,769,935$ & $162,761,605$ & $104,021,891$ & 56.501 .900 & $9,905,817$ & $45,320,9 \pi$ & $898,743,300$ & $.54,409,220$ \\
\hline
\end{tabular}


TABLE 8. Raw Material Requirements in Thousands of Metric Tons for AIPH Systems, Individual Systems at $500 \mathrm{~m}$. sq. m. and A11 3 Systems Totaling $500 \mathrm{~m}$. sq. m. in the Combined Scenario.

\begin{tabular}{|c|c|c|c|c|}
\hline Materials & $\begin{array}{l}\text { Chamberlain } \\
\text { Lumber Kiln }\end{array}$ & $\begin{array}{l}\text { LLL Solar } \\
\text { Pond }\end{array}$ & $\begin{array}{c}\text { Honeywell } \\
\text { Concentrating } \\
\end{array}$ & $\begin{array}{l}500 \text { Million } M^{2} \\
\text { Mixed Scenario } \\
\end{array}$ \\
\hline Asbestos & 1 & 191 & 5 & 131 \\
\hline Bauxite & 26,910 & 106 & 18,615 & 30,482 \\
\hline Borate & 282 & 54 & 331 & 445 \\
\hline Chromite & 621 & & 121 & 496 \\
\hline Clays & 914 & 7,518 & 155 & 5,736 \\
\hline Coal & 112,533 & 9,621 & 23,654 & 97,400 \\
\hline Coal, Bitum. & 43,999 & 2,338 & 220,873 & 178,496 \\
\hline Copper ore & 289,563 & 15,381 & 166,585 & 314,982 \\
\hline Feldspar & 940 & 120 & 14 & 717 \\
\hline Fluorspar & 1,052 & 50 & 378 & 988 \\
\hline Gypsum & & 2,475 & & 1,654 \\
\hline Iron ore & 486,035 & 21,488 & 79,607 & 392,203 \\
\hline Lead ore & 147 & 2 & 13 & 108 \\
\hline Lime & & - & 0 & 0 \\
\hline Manganese & 2,845 & 127 & 462 & 2,293 \\
\hline Mercury & & & 0 & 0 \\
\hline Molybdemum ore & & & 480 & 321 \\
\hline Natural gas & 2,037 & 4,183 & 611 & 4,563 \\
\hline Nickel ore & & & 2,719 & 8,676 \\
\hline Nitrogen Fix. & & 0 & 0 & 0 \\
\hline Oxygen & 141 & & 0 & 94 \\
\hline Petroleum & 5,504 & 235 & 879 & 4,421 \\
\hline Propane & & & 197 & 131 \\
\hline Salt & 32,420 & 1,123 & 14,771 & 32,274 \\
\hline Sand \& Gravel & 7,392 & 143,857 & 1,053 & 101,738 \\
\hline Silver ore & 10,651 & 162 & & 7,223 \\
\hline Stone & & 207,636 & & 138,701 \\
\hline Sulfur. & 1,372 & 21 & 954 & 1,568 \\
\hline Tin ore & 74,554 & 1,999 & 14,035 & 60,513 \\
\hline Zinc ore & 13,376 & 733 & 3,415 & 11,706 \\
\hline Cotton & 556 & & & 371 \\
\hline Milk byprod. & 27 & 0 & 0 & 18 \\
\hline Lumber & 38,490 & 129 & 5 & 25,801 \\
\hline Seawa ter & 5 & 0 & 233 & 159 \\
\hline Water & 874,551 & 56,665 & 7,347 & 626,960 \\
\hline Wheat & & 0 & & 0 \\
\hline Misc. & 1,520 & 94 & 416 & 1,356 \\
\hline Steam & 239,973 & 5,648 & 109,136 & 236,978 \\
\hline Limestone & 71,837 & 74,078 & 18,817 & 110,041 \\
\hline Coal byprod. & 833,807 & 593,838 & 128,274 & $1,039,354$ \\
\hline Electricity & $4,274,689$ & 253,503 & 198,225 & $3,157,247$ \\
\hline \multirow{2}{*}{$\begin{array}{l}\text { Coal byprod. } 2 \\
\text { TOTAL }(a)\end{array}$} & 370,329 & 24,531 & & 263,766 \\
\hline & $2,340,748$ & 556,034 & 685,881 & $2,399,744$ \\
\hline
\end{tabular}

a. Not including byproduct and electricity. 
TABLE 9. Bulk Material Requirements in Metric Tons for AIPH Systems at 500 Million Square Meters. Individual Systems at $500 \mathrm{~m}$. sq. m. and Mixed Scenario--A11 3 Systems at $167 \mathrm{~m}$. sq. m. each, Totaling $500 \mathrm{~m}$. sq. m.

\begin{tabular}{|c|c|c|c|c|}
\hline Materials & $\begin{array}{l}\text { Chamberlain } \\
\text { Lumber Kiln }\end{array}$ & $\begin{array}{c}\text { LLL Solar } \\
\text { Pond }\end{array}$ & $\begin{array}{c}\text { Honeywe } 11 \\
\text { Concentrating }\end{array}$ & $\begin{array}{l}500 \mathrm{Million} \mathrm{M}^{2} \\
\text { Mixed Scenario }\end{array}$ \\
\hline Aluminum & $5,192,320$ & 1,267 & $3,569,043$ & $2,926,719$ \\
\hline Asbestos & 2,562 & 190,338 & 2,000 & 64,441 \\
\hline Cadmium & 207,095 & 172 & & 913 \\
\hline Cement & & $51,571,012$ & & $17,224,718$ \\
\hline Chromium & & & 16,099 & 74,547 \\
\hline Copper & $1,316,198$ & 69,914 & 757,203 & 715,867 \\
\hline Glass fibers & $1,127,280$ & 214,500 & $1,325,346$ & 890,820 \\
\hline Glass sodalime & $10,103,247$ & $1,287,000$ & 154,800 & $3,856,046$ \\
\hline Iron, Steel & $85,477,352$ & $3,723,924$ & $13,718,863$ & $34,375,328$ \\
\hline Lead & 4,407 & 67 & 392 & 1,625 \\
\hline Magnesium & & & 323 & 108 \\
\hline Ferromanganese & 516,352 & 23,257 & 83,382 & 208,079 \\
\hline Mercury & & & 13 & 4 \\
\hline Mo lybdenum & & & 640 & 214 \\
\hline Nickel & 102,694 & & 18,024 & 40,320 \\
\hline Porcelain & & 185 & 65 & 83 \\
\hline Sand \& Grave 1 & & $139,926,624$ & 56,115 & $46,754,236$ \\
\hline Stone & & $207,635,520$ & & $69,350,264$ \\
\hline Silicon & 4,532 & 8,994 & 8,437 & 7,335 \\
\hline Silver & 1,494 & 23 & 221 & 507 \\
\hline Sulfur & & & & 74 \\
\hline Tin & 7,455 & 200 & 1,404 & 3,026 \\
\hline Water & $41,632,500$ & $52,975,000$ & $1,059,090$ & $31,952,642$ \\
\hline Zinc & 722,307 & 39,225 & 191,846 & 318,428 \\
\hline Stainless Steel & & & 114,616 & 38,282 \\
\hline Acrylic & & & 84,495 & 28,221 \\
\hline Epoxy resin & & & 252,840 & 84,449 \\
\hline Glue & & 1,463 & & 488 \\
\hline Lumber softwood & $38,003,000$ & & & $12,693,002$ \\
\hline Phenolic resin & 796,355 & & 7,095 & 268,352 \\
\hline Pve plastic & 309,575 & 39,127 & 6,192 & 118,535 \\
\hline Tefion & 1,494 & & 9,804 & 3,774 \\
\hline Cotton fibers & 555,954 & & & 185,689 \\
\hline Kraft fibers & 238,266 & 64,350 & & 101,074 \\
\hline Urethane & 625,555 & 41,438 & & 222,776 \\
\hline Neoprene & & 15,470 & 161,250 & 59,024 \\
\hline Pitch & & & 702,405 & 234,603 \\
\hline Polyvinyl fluo. & & 19,175 & & 6,404 \\
\hline EPDM rubber & 239,120 & & 65 & 79,888 \\
\hline Polyester resin & & 500,500 & & 167,167 \\
\hline TQTAL & $187,187,114$ & $458,348,745$ & $22,302,068$ & $223,058,072$ \\
\hline
\end{tabular}



IIETHODS, MODELS, AND ASSUMPTIONS USED TO IDENTIFY POTENTIAL MATERIALS CONSTRAINTS $(7,8)$

One usually thinks of the flow of materials proceeding from raw materials to the engineering materials (Figure 1). Take, for example, copper. Copper ore is mined and sent to a mill and smelter. The bulk material copper that leaves this process may be formed into an engineering material like brass. This brass may then be incorporated into a solar device. The tracking process used by the critical materials assessment model follows the opposition direction. First, the amount of brass in the solar device is characterized. Then this engineering material is translated into its bulk materials one of which is copper. At this point, the bulk material copper would be reviewed for possible capacity constraints. Next, the copper would be translated into its raw materials, copper ore, asbestos, clays, coal, fluorspar, etc. The copper ore and all of the other raw materials are then checked for potential capacity constraints and for availability of reserves and resources.

\section{THE MATERIALS CYCLE}

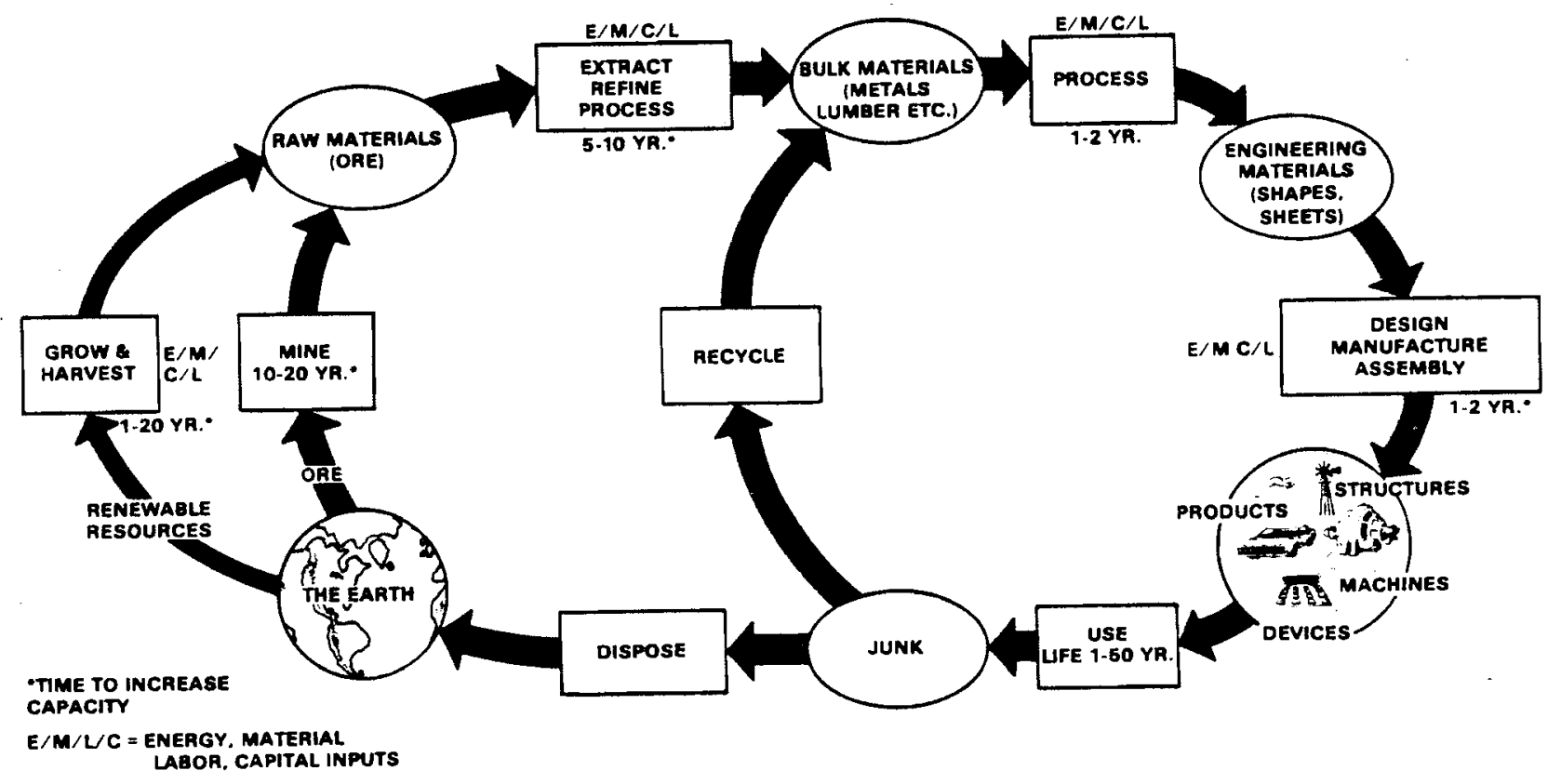

FIGURE 1. The Materials Cycle 
This process of tracking the materials and examining their use for potential constraints involves large quantities of data and consequent arithmetic. Thus, much of the methocology was organized and placed on an interactive computer system.

That part of the methodology which was placed on the computer includes all of the steps down to and including those steps labeled screening in Figure 2. Figure 3 shows the flexibility which resulted from making the program interactive. The top blocks of user supplied input is all available to change at the terminal, while the cases are being examined. The bottom left block lists material which is entered by card deck. Of course, this material can also be updated periodically, but cannot be changed at the terminal.

The specific questions raised by the computer and answered from the stored data base are shown on Figure 4 which highlights the logic of the methodology. The questions raised by the computer are reviewed subsequently in a manual process where materials are classified as "A", "B", or "C" materials.

"A" materials are those materials regarded as causing possible constraints in the large scale implementation of particular solar designs and thus requiring further review. "B" materials are those that exceed some threshold levels, but also show by the printed data that they are not likely to present a serious constraint to future deployment. An example is antimony. It is largely imported and is derived as a byproduct, but it is used in such small quantities that it is unlikely to be a serious problem. Thus, it is classified as a "B" material. "A" materials on the other hand, require further study using data not supplied in the computer printout and may in fact require a mitigating strategy to avoid serious constraints in future solar systems construction schedules. "C" materials are those materials that do not exceed any of the threshold levels and are not expected to present future material constraints.

These threshold levels may be changed at any time from the computer terminal. The threshold values used for this study are shown in Table 10 for bulk materials and Tablell for raw materials. Following the tables, the sensitivity of the study to the major assumptions is discussed. 


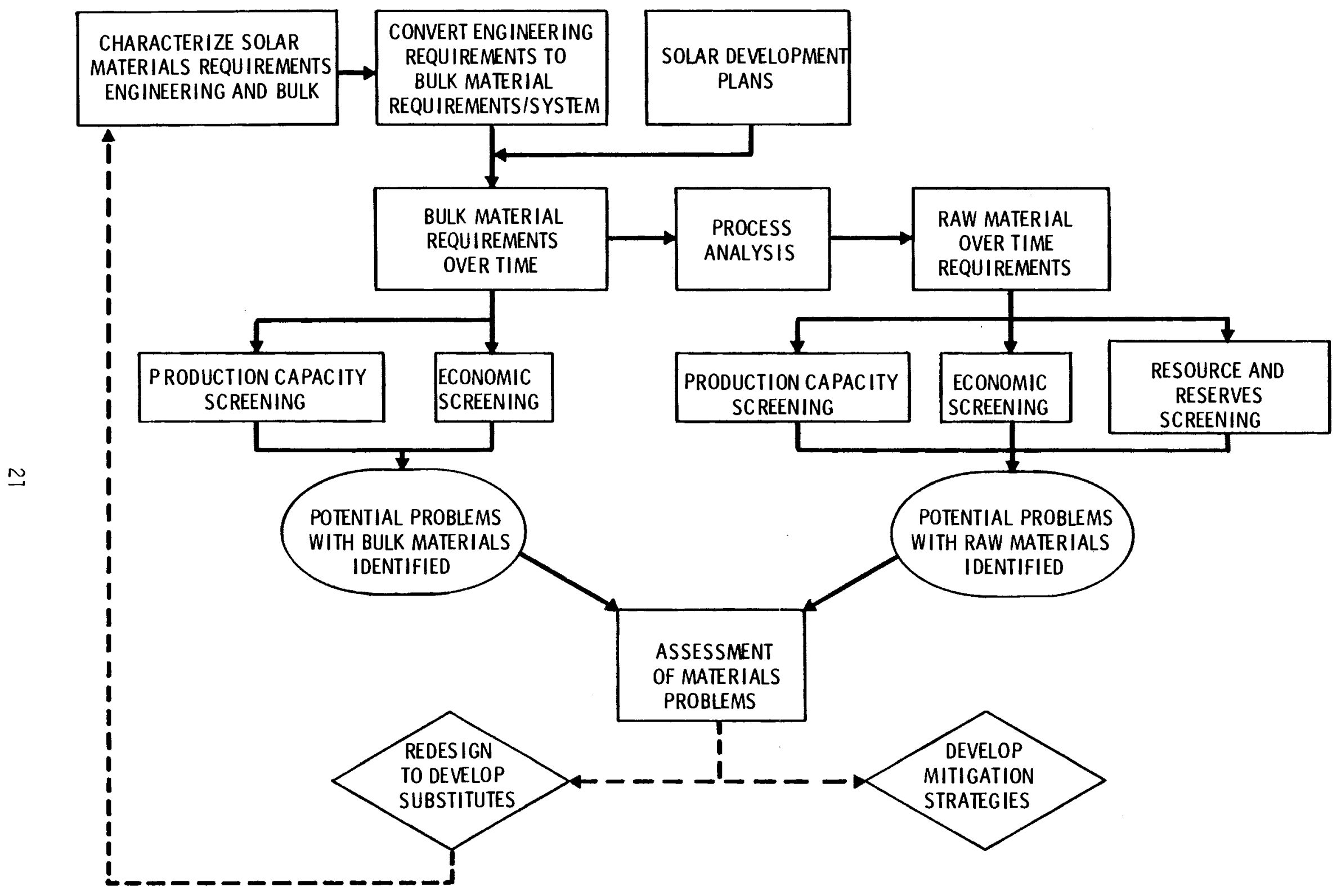

FIGURE 2. Flow Chart of Materials Assessment Methodology 


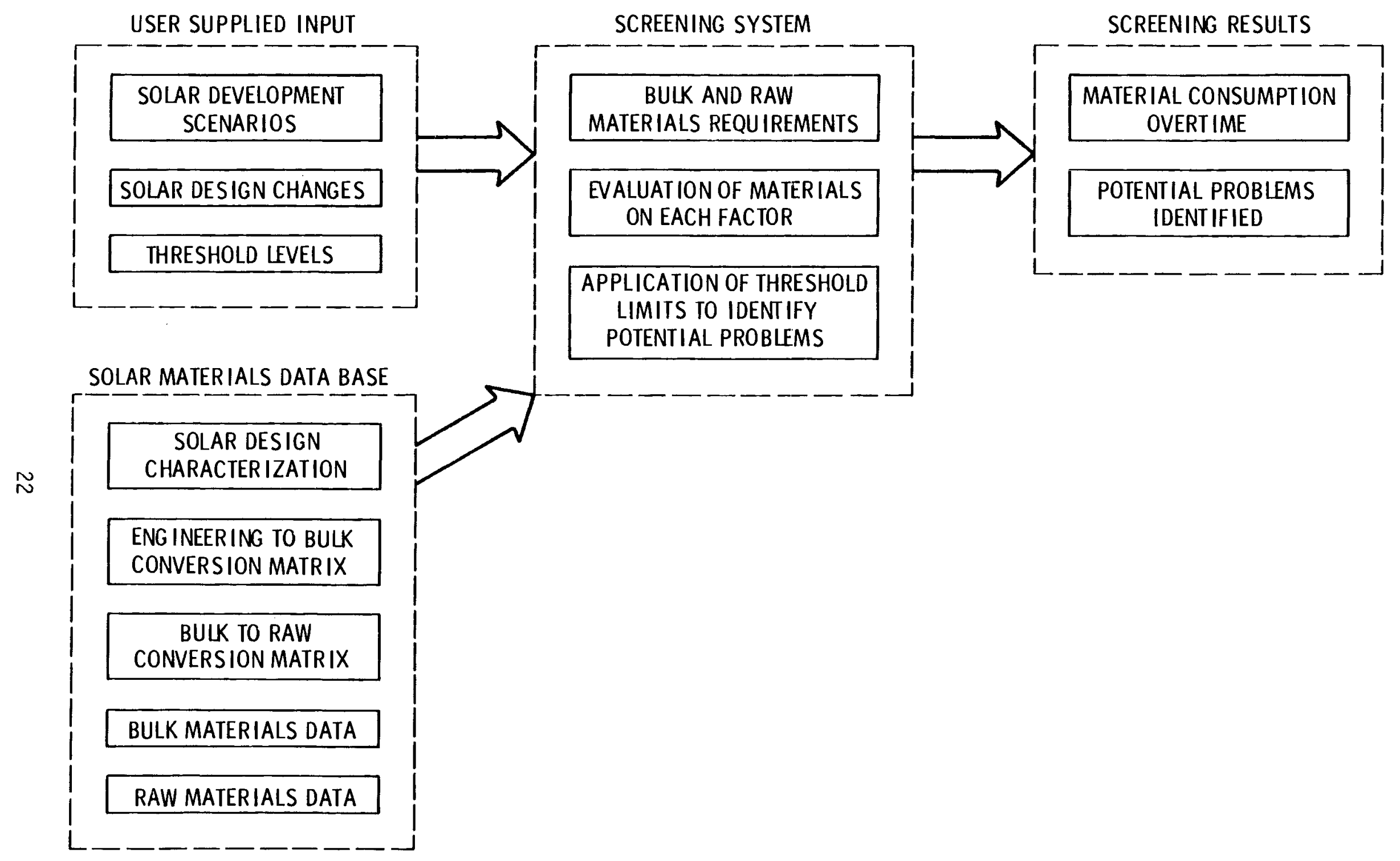

FIGURE 3. Interactive Screening System 


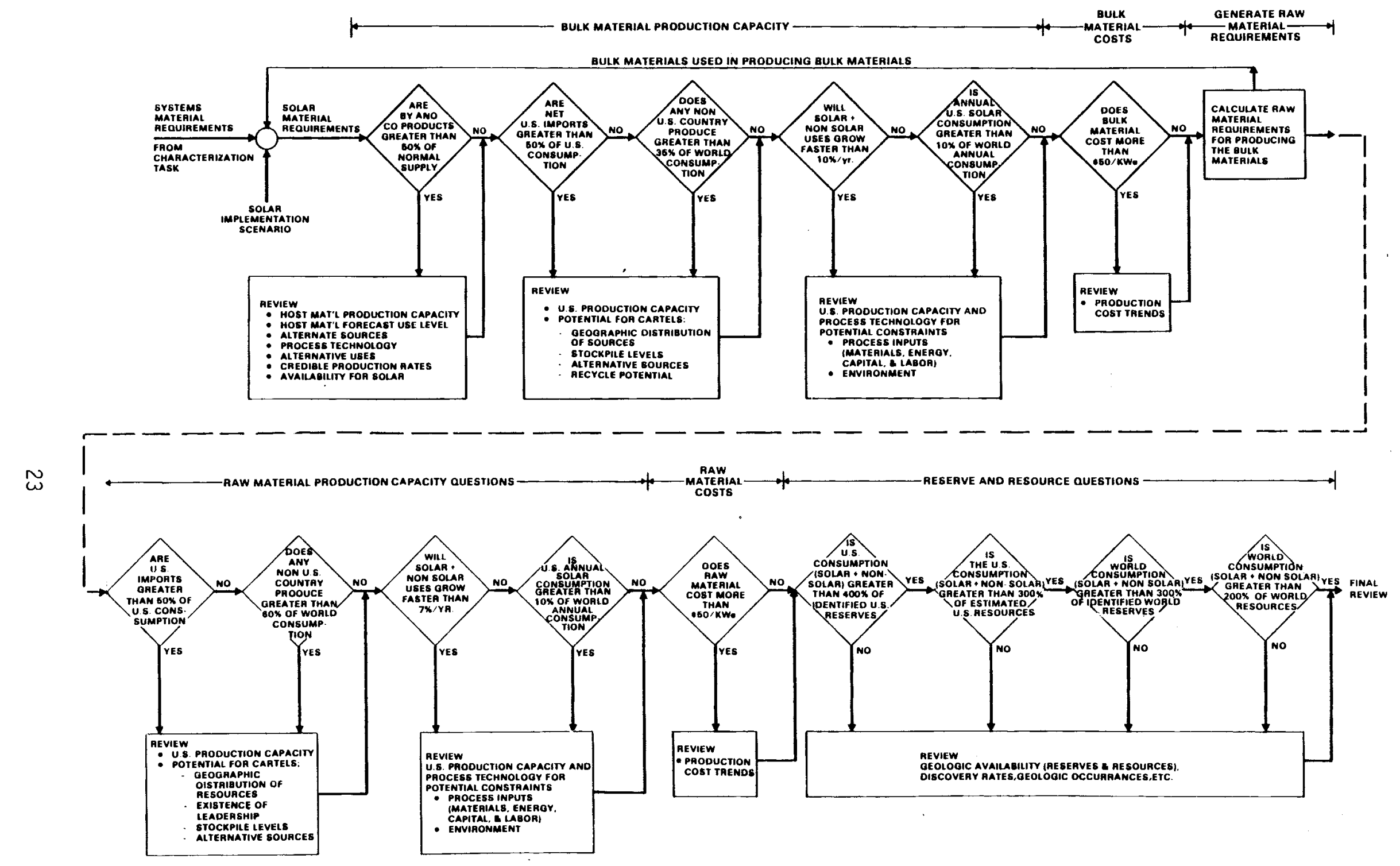

FIGURE 4. Assessment of Potential Materials Problems 
TABLE 10. Bulk Material Threshold Criteria

\begin{tabular}{lll} 
Factor & $\begin{array}{c}\text { Value } \\
\text { Selected }\end{array}$ & \multicolumn{1}{c}{ Reason Selected } \\
\hline $\begin{array}{l}\text { Percent supplied as a } \\
\text { byproduct }\end{array}$ & $50 \% \quad \begin{array}{l}\text { If a large percentage of normal supply is } \\
\text { derived as a by-product, it may be extreme- }\end{array}$ \\
& $\begin{array}{l}\text { ly difficult to expand production, In our } \\
\text { judgment, when 50\% of normal supplies are } \\
\text { dependent on the production of a primary } \\
\text { material, ones ability to expand produc- } \\
\text { tion significantly is uncertain. }\end{array}$
\end{tabular}

Percent of current consumption that is imported

$50 \%$

Percent of worid consumption

$35 \% \quad$ Price leadership and the possibilities of cartels and geopolitical problems are important when approximately $35 \%$ of current supply originates in a single non-U.S. supplier.

Production growth rate neces- $10 \%$ sary to meet forecasted world consumption and solar requirements

The largest single year market $10 \%$ share consumed by solar over the period of the development pian (solar's \% of world's consumption)

A sustained compound growth rate of 10\% per year is unusual for most bulk material production processes and frequently puts severe pressures on capital, labor, and the environ- . ment.

The contributions to capital $15 / \mathrm{M}^{2}$ costs per unit of peak power

When a single consumer of a material represents $10 \%$ of world consumption, the possibility exists to significantly influence market prices.

$\$ 15 / M^{2}$ would represent about $5 \%$ of the selling price of a typical system. 
TABLE 11. Raw Material Threshold Criteria

\section{Factor}

Percent of current consumption that is imported

Percent of world consumption supplied by the largest supplier country outside of the U.S.

Production growth rate necessary to meet forecasted world consumption and solar requirements

Largest single year market share consumed by solar over the period of the solar development plan

Percent of the world reserves that will be consumed by the year 2000

Percent of the U.S. reserves that will be consumed by the year 2000 value Selected

$50 \%$

Reason Selected

When a large percentage of a material originates outside of the U.S., the uncertainty surrounding future materials prices and availability is increased. Fifty percent of current materials consumption resulting from imports may not represent a problem if all imports do not originate in a few countries. However, the 50\% level was selected as a general level of concern.

$60 \%$ Raw materials suppliers tend to be larger and, therefore, control a larger percentage of the market than bulk material suppliers. When a single supplier controls $60 \%$ of world consumption, raw materials availability is a potential problem.

$7 \%$ The time required to develop raw material supplies is from 5-20 years and a 7\% compound growth rate appears to be an appropriate level of concern.

$10 \%$ When a single consumer of a material represents $10 \%$ of world consumption, the possibility exists to significantly influence market prices.

$300 \%$ A frequently used rule of thumb for appropriate reserve margins is 10 years at current consumption. With respect to using world reserves, we anticipate possible problems if we wish to consume 3 times known reserves over the next 20 years. This represents planned consumption of $300 \%$ of known world reserves.

$400 \%$ Because U.S. reserves are much more certain, extensive use of reserves, up to 4 times the currently known reserves, may not be a problem. 
TABLE 11. (Continued)

\section{Factor}

Percent of world resources that will be consumed by the year 2000

Percent of U.S. resources that will be consumed by the year 2000

The contribution to capital costs of raw materials per unit of peak power
Value Selected $200 \%$ The definition of resources includes presently uneconomic deposits and, therefore, consumption of a larger percentage may be a problem. A reasonable estimate appears to be in the range of $200 \%$. Thus, if we plan on consumption of 2 times currently known resources we anticipate raw material availability problems.

$300 \% \quad$ U.S. resources have less uncertainty than do world resources. We estimate that up to 3 times currently known deposits can be consumed by 2000 .

$\$ 15 / M^{2} \quad \$ 15 / M^{2}$ would represent about $5 \%$ of the selling price of a typical system. 
THE EFFECT OF THE ASSUMPTIONS MADE IN THE STUDY

A major part of the study centers around the assumption that 500 million square meters of collectors will be installed for a given design by the year 2000. Both the total quantity and the rate at which installation occurs are important for specific criteria.

For SHACOB, a total installation of 500 million square meters of collector area will yield an annual solar contribution of nearly 0.7 Quads or will displace approximately 2.0 Quads of fossil fuel used in generating electricity. If the average SHACOB residential installation is 40 square meters ${ }^{(9)}$ then 500 million square meters of collectors would represent nearly 13 million residential SHACOB installations.

For AIPH, a total installation of 500 million square meters of collectors will yield an annual solar contribution of one to two Quads depending upon the mix of types of AIPH systems installed.

The rates at which various technologies will be installed in the future is, of course, unknown; however, a number of studies have examined past technology diffusion rates and some things are foreseeable. Technologies are unlikely to be installed in a uniform manner (constant rate) for a sustained period. They are more likely to be described by a function which has been described as an "S" curve. This study assumes the year 2000 as the end point of the study and we felt that most solar technologies could better be described by an exponential growth curve which approximates the first part of an "S" curve (see Figure 5).

The maximum rate is about $15 \%$ of the total for the exponential curve chosen assuming a starting date of 1985. This is, of course, about $21 / 2$ times the rate which would be encountered if a uniform rate of installation were assumed. We feel that the analysis resulting is properly more conservative than a uniform rate would entail and yet doesn't unduly penalize the technology. In practical terms you can't start a business at full speed instantly and on the other hand, we shouldn't assume a scenario which is so severe on a single year that this alone causes a shock to materials supply chains which could actually limit the solar installations to a more rational rate. 


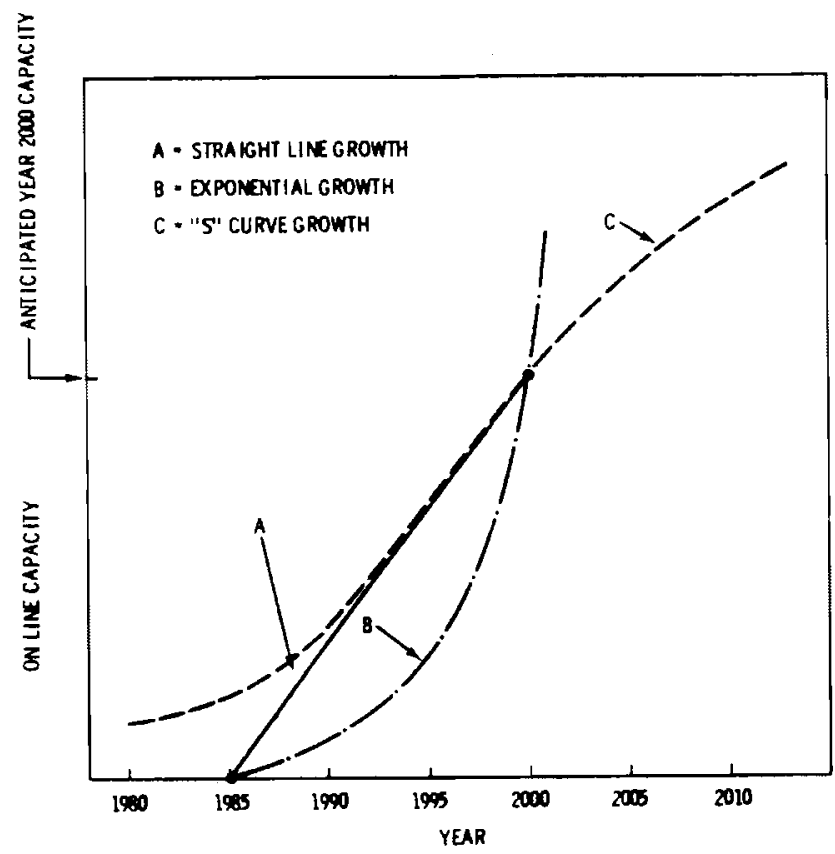

FIGURE 5. Growth Curves for Solar Systems Deployment. Exponential growth assumed in this study.

The selection of levels for the screening criteria used in the computer model are very important in determining which materials are selected for further review. The following paragraphs will describe the values selected and give some of the rationale behind the selection and an indication of its sensitivity to putting materials into the "critical zone" for bulk and also for raw materials.

\section{Bulk Material Criteria Threshold Levels}

\section{Percent Supplied as a Byproduct}

This criteria has been set to respond at the $50 \%$ level. In effect, we have set the level to indicate if a material is primarily obtained as a byproduct. It is difficult to defend this exact value, but fortunately, the raising of this number to the $65 \%$, or lowering it to $35 \%$, would not add or subtract even one material from those triggered in this study. 
Any material which has its "mode" of supply coming as a byproduct should be watched in the future since changes in the primary product process could totally eliminate the secondary material source. However, we have in this study, ruled that a material having more than $50 \%$ of its normal supply derived as a byproduct does not cause the material to become "critical" (i.e., an "A" material), unless solar's percent of consumption is also large or the world production growth rate is excessive or the cost per square meter for the system is excessive.

World Production Growth Rate

This particular indicator was set for this study to raise a flag at a $10 \% / y r$. We realize that this level is easily exceeded for some materials but that for others it is difficult to reach. We set it at $10 \%$ and then review those materials for which the flag is raised to see if we should really consider it to be truly critical to the technology. A single value for this one doesn't fit every material.

Solar's Percent of World Consumption

We used $10 \%$ for this threshold level. This is the general range in which solar needs might start to drive the market. This could mean opportunities for reductions in cost (by purchasing materials in large quantities) or it could signal suppliers they have someone who "needs the product" and thus, forcing up the price of materials. In any case, suppliers will no longer consider solar just another little piece of the market. This one can be plus or minus depending on risk perceived by those supplying the solar market. It is considered to be an important indicator. 


\section{Percent From Largest Country Outside United States}

We used $35 \%$ for the threshold level here. The level chosen is not critical for this study for two reasons. The first reason is that few materials would switch categories if you went to $40 \%$ or reduced to $30 \%$ and the second is that getting a flag on this one is enough to raise a material into the "B" category where you should watch it in the future, but we require heavy usage or a high dollar content to reinforce the potential impact on the construction of future system (i.e., become truly critical).

Cost Per Unit of Output

We have selected $\$ 15 / M^{2}$ for this threshold level. This level is one at which future prices become very interesting. A doubling or tripling of prices in the future could jeopardize the "learning curve" reductions expected for the technology unless appropriate action is taken.

In other words, if bulk material costs add up to some significant cost level, this may form an uncomfortably high floor under expected cost in the future. This criteria alone is enough to indicate a need for a careful review of mitigating strategies and future price trends.

Net Percent Imported

We have selected $50 \%$ as the threshold level for this criteria. This again is a criteria which by itself is not highly critical to the construction of solar technologies unless large quantities of the material are used for solar or the material is an expensive part of the design. Changing the level to $75 \%$ or $25 \%$ will not affect the number of materials significantly which are designated as "A" materials, although it would substantially change the number of materials in the "B" plan (should be watched in the future). 
Raw Material Criteria Threshold Levels

World Production Growth Rate

The $7 \%$ threshold selected for this criteria is heuristically selected. The consequences of increasing this level in this study would be negligible. Decreasing the threshold substantially would be hard to justify since many raw materials have had sustained growth rates in this range. Decreasing the level would add many materials to the "B" list of materials to be watched in the future. High production growth rates are primarily an indication of potential market pressures which could increase the costs. High growth rates are not necessarily terribly important to solar needs unless they are accompanied by high costs in solar or the high growth rate was occasioned by solar needs which would show up as a high "Solar Percent of World Production."

Maximum Percent for Solar

We selected $10 \%$ for this threshold level. This criteria is felt to be important, but it is difficult to justify selection of a specific level. We have examined the impact of changing the level and find that a change affects few materials in this study as many of the materials are also used in large quantities in the manufacturing industry and in construction activities.

U.S. Reserves and Resources Consumed by the Year 2000 and World Reserves and Resources Consumed by the Year 2000

The four threshold levels selected $(400 \%, 300 \%, 300 \%$, and $200 \%)$ cannot be defended in any precise way, but minor changes in these criteria do not really affect the outcome of the study. This is because most of those materials which exceed these threshold values in this study are used in small quantities and/or do not cost must per kWe in the system, or their use is so large that raising the limit wouldn't change the result anyway. 
The Percentage From the Largest Non U.S. Country.

The selection of $50 \%$ for this threshold level is not critical. Raising it to $60 \%$ or lowering it to $40 \%$ would not change the status of a single "A" level material.

Present Costs in $\$ / M^{2}$

The selection of $\$ 15 / \mathrm{M}^{2}$ corresponds to roughly $5 \%$ of system cost. Intensive efforts will no doubt be applied by a manufacturer to decrease the usage or substitute for any material getting into this general range. But up to this level, in all probability, it would be possible to reduce costs by reducing other cost segments even if this one went up. Above the $5 \%$ level, somewhere a given material could place a highly resistant floor under the minimum of a learning curve. Costs in $\$ / M^{2}$ are regarded as a highly significant criteria.

\section{Net Percentage Imported}

This criteria by itself is not considered to be sufficient to cause a material to be a probable barrier to solar deployment unless it is accompanied by high usage rates in solar and/or a high $\$ / M^{2}$ for the study. Changing the level from the $50 \%$ chosen for the study to $60 \%$ or $40 \%$ will cause a number of materials to move into or out of the should be watched category; but won't cause many changes in the materials classified as real potential barriers to the deployment of solar. 


\section{RESULTS AND RECOMMENDATIONS}

The nine SHACOB and three AIPH systems were screened by the computer and found to be relatively free of serious future material constraints. The screening was carried out in scenarios composed of one individual system design totaling 500 million $\mathrm{m}^{2}$ of collector area installed by the year 2000 . Also mixed design scenarios, containing equal portions of each system design, were carried out separately for $S H A C O B$ and AIPH at 500 million $^{2}$ and a billion $\mathrm{m}^{2}$ of collector area installed by the year 2000 .

To keep these scenarios in perspective, note that a billion $\mathrm{m}^{2}$ containing a mixture of the nine SHACOB designs will yield an annual solar contribution of about 1.3 Quads or will displace about 4.2 Quads of fossil fuel used to generate electricity. For AIPH a billion $\mathrm{m}^{2}$ of the mixed designs will yield about 2.8 Quads/year.

Three materials were identified that could possibly restrain the deployment of solar systems in the specific scenarios investigated. Iron and steel exceeded the threshold for the cost criteria $\left(\$ 15 / \mathrm{m}^{2}\right)$ in two SHACOB systems, in one AIPH system, and in the AIPH mixed design scenarios. Glass consumption in the billion $\mathrm{m}^{2}$ mixed SHACOB scenario exceeds $10 \%$ of the world consumption. Polyvinyl fluoride consumption exceeds $18 \%$ of the world consumption for one SHACOB system. All three of these materials are bulk materials. No raw material constraints were found.

The complete results of the computer screening for all the scenarios are given in Appendix $A$. The screening results are summarized in Tables 12, 13, 14, and 15, where the problem materials are classified either "A" materials needing further review as a possibly serious problem for future large scale use, or as "B" materials - not likely to present a serious constraint. Materials not 
TABLE 12. Problem Bulk Materials in SHACOB Systems

Individual Systems at 500 Million Square Meters by the Year 2000.

Mixed Designs at 500 and 1000 Million Square Meters - Equal Portions of All Nine Designs.

\begin{tabular}{|c|c|c|c|c|c|c|c|c|c|c|c|}
\hline Bulk Material & $\begin{array}{c}\text { Sunworks } \\
\text { Res HW }\end{array}$ & $\begin{array}{r}\text { Solaron } \\
\text { Res HT }\end{array}$ & $\begin{array}{l}\text { Solaron } \\
\text { Res } \\
\mathrm{HT}+\mathrm{HW}\end{array}$ & $\begin{array}{l}\text { Amer } \\
\mathrm{Helio} \\
\mathrm{H}+\mathrm{HW}\end{array}$ & $\begin{array}{l}\text { KTA and } \\
\text { Ecosol } \\
\text { Heat Pump } \\
\text { Sys } \\
\end{array}$ & $\begin{array}{l}\text { Ray Pak } \\
\mathrm{HT}+\mathrm{Cool}+\mathrm{HH} \\
\end{array}$ & $\begin{array}{c}\text { Trombe } \\
\text { Ilall } \\
\text { Concrete }\end{array}$ & $\begin{array}{c}\text { Trombe } \\
\text { Wall } \\
\text { Water }\end{array}$ & $\begin{array}{l}\text { Direct } \\
\text { Gain } \\
\text { Masonry } \\
\text { Wall }\end{array}$ & $\begin{array}{c}\text { Mixed } \\
\text { Designs } \\
500 \times 106 \mathrm{M} 2 \\
\end{array}$ & $\begin{array}{c}\text { Mixed } \\
\text { Designs } \\
1000 \times 10^{6}, 12\end{array}$ \\
\hline Antimony & B & & & & & & & & & B & B \\
\hline Asbestos & & & & & & B & & & & B & B \\
\hline Cadmium & & & & & & B & & & & B & B \\
\hline Carbon Black & & & & & B & & B & B & & B & B \\
\hline Chromi um & B & & & & & B & & & & B & B \\
\hline Glass, Soda Lime & & & & & & & & & & & A \\
\hline
\end{tabular}

Iron, Steel

A

Ferromanganese

B

B

B

B

A

Mercury

Nickel

Silver

Tin

Zinc

Polyvinylfluoride

$\begin{array}{lllll}\text { B } & \text { B } & & \text { B } \\ \text { B } & \text { B } & \text { B } \\ & & & & \text { B } \\ & & & \text { A }\end{array}$

$A=$ Significant Problem - Additional Assessment Necessary

$B=$ Potential Problem - Supply Should be Monitored 
TABLE 13. Problem Raw Materials in SHACOB Systems

Individual Systems at 500 Million Square Meters by the Year 2000.

Mixed Designs at 500 and 1000 Million Square Meters - Equal Portions of All Nine Designs.

\begin{tabular}{|c|c|c|c|c|c|c|c|c|c|c|c|}
\hline Raw Material & $\begin{array}{c}\text { Sunworks } \\
\text { Res HW }\end{array}$ & $\begin{array}{r}\text { Solaron } \\
\text { Res HT }\end{array}$ & $\begin{array}{c}\text { Solaron } \\
\text { Res } \\
\mathrm{HT}+\mathrm{HW}\end{array}$ & $\begin{array}{c}\text { Amer } \\
\text { Helio } \\
H+H W\end{array}$ & $\begin{array}{c}\text { KTA and } \\
\text { Ecosol } \\
\text { Heat Pump } \\
\text { Sys } \\
\end{array}$ & $\begin{array}{l}\text { Ray' Pak } \\
\mathrm{HT}+\mathrm{Cool}+\mathrm{HW}\end{array}$ & $\begin{array}{c}\text { Trombe } \\
\text { Wall } \\
\text { Concrete }\end{array}$ & $\begin{array}{c}\text { Trombe } \\
\text { Wall } \\
\text { Water }\end{array}$ & $\begin{array}{l}\text { Direct } \\
\text { Gain } \\
\text { Masonry } \\
\text { Wall }\end{array}$ & $\begin{array}{c}\text { Mixed } \\
\text { Designs } \\
500 \times 10^{6} \mathrm{M} 2 \\
\end{array}$ & $\begin{array}{c}\text { Mixed } \\
\text { Designs } \\
1000 \times 10^{6} \mathrm{M}^{2}\end{array}$ \\
\hline Antimony Ore & B & & & & & & & & & B & B \\
\hline Asbestos & B & B & B & B & B & B & B & B & B & B & B \\
\hline Bauxite & B & B & B & B & B & B & B & B & B & B & B \\
\hline Chromite & B & & B & & & B & & B & & B & B \\
\hline Copper Ore & B & B & B & B & B & B & & & & B & B \\
\hline Fluorspar & B & B & B & B & B & B & B & B & B & B & B \\
\hline Lithium 0re & & & & & & B & & & & B & B \\
\hline Manganese Ore & B & B & B & B & B & B & B & B & B & B & B \\
\hline Mercury Ore & & & & & & B & & & & B & B \\
\hline Nickel Ore & B & & B & & & B & & & & B & B \\
\hline Petroleum & B & B & B & B & B & B & B & B & B & B & B \\
\hline Tin Ore & B & & B & & B & B & & & & B & B \\
\hline Zinc Ore & B & B & B & B & B & B & & & & B & B \\
\hline Petroleum Byproduct & & & & & & B & & & & B & B \\
\hline
\end{tabular}

$B=$ Potential Problem - Supply Should be Monitored 
TABLE 14. PROBLEM BULK MATERIALS IN AIPH SYSTEMS

INDIVIDUAL SYSTEMS AT 500 MILLION SQUARE METERS BY THE YEAR 2000

MIXED DESIGNS AT 500 AND 1000 MILLION SQUARE METERS EQUAL PORTIONS OF ALL THREE DESIGNS

\begin{tabular}{|c|c|c|c|c|c|}
\hline BULK MATERIAL & $\begin{array}{l}\text { LLL } \\
\text { Solar } \\
\text { Pond } \\
\end{array}$ & $\begin{array}{c}\text { Chamberiain } \\
\text { Lumber } \\
\mathrm{Ki} \text {.n }\end{array}$ & $\begin{array}{c}\text { Honeywell } \\
\text { Concentrating }\end{array}$ & $\begin{array}{c}\text { Mixed } \\
\text { Designs } \\
500 \times 106 \mathrm{M}^{2} \\
\end{array}$ & $\begin{array}{c}\text { Mixed } \\
\text { Designs } \\
1000 \times 10^{2} \mathrm{M}^{2} \\
\end{array}$ \\
\hline Asbestos Ore & $B(b)$ & & B & B & B \\
\hline Cadmium & B & B & & B & B \\
\hline Chromium & & B & B & B & B \\
\hline Iron, Steel & & $A(a)$ & & A & A \\
\hline Ferromanganese & B & B & B & B & B \\
\hline Mercury & & & B & B & B \\
\hline Nickel & & B & B & B & B \\
\hline Silver & B & 8 & & B. & B \\
\hline Tin & B & B & B & B & B \\
\hline Zinc & B & B & B & $B$ & B \\
\hline
\end{tabular}

(a) $A=$ Significant problem - additional assessment necessary.

(b) $B=$ Potential problem - supply siould be monitored. 
TABLE 15. PROBLEM RAW MATERIALS IN AIPH SYSTEMS

INDIVIDUAL SYSTEMS AT 500 MILLION SQUARE METERS BY THE YEAR 2000 MIXED DESIGNS AT 500 AND 1000 MILLION SQUARE METERS EQUAL PORTIONS OF ALL THREE DESIGNS

\begin{tabular}{|c|c|c|c|c|c|}
\hline RAW MATERIAL & $\begin{array}{l}\text { LLL } \\
\text { Solar } \\
\text { Pond } \\
\end{array}$ & $\begin{array}{c}\text { Chamberlain } \\
\text { Lumber } \\
\mathrm{Ki} 7 \mathrm{n} \\
\end{array}$ & $\begin{array}{c}\text { Honeywe } 11 \\
\text { Concentrating }\end{array}$ & $\begin{array}{c}\text { Mixed } \\
\text { Designs } \\
500 \times 10^{6} \mathrm{M}^{2} \\
\end{array}$ & $\begin{array}{c}\text { Mixed } \\
\text { Designs } \\
1000 \times 106 \mathrm{M}^{2} \\
\end{array}$ \\
\hline Asbestos Ore & $B(a)$ & B & B & B & B \\
\hline Bauxite & B & B & B & B & B \\
\hline Chromite & & B & B & B & B \\
\hline Copper Ore & E & B & B & B & B \\
\hline Fluorspar & B & B & B & B & B \\
\hline Manganese Ore & B & B & B & B & B \\
\hline Mercury Ore & & & B & B & B \\
\hline Nickel Ore & & B & B & B & B \\
\hline Petroleum & B & B & B & B & B \\
\hline Tin Ore & B & B & B & B & B \\
\hline Zinc Ore & B & B & B & B & B \\
\hline
\end{tabular}

(a) $B=$ Potential probiem--supply should be monitored. 
exceeding the screening criteria threshold vaiues are classed as "C" materials posing no problems. "C" materials are not listed in Tables 12, 13, 14, and 15. Please keep in mind that the $A-B-C$ ratings are scenario specific.

The reasons for classifying the materials as either "A" or "B" will become clear in the following discussions of the "A" and "B" materials.

"A" MATERIALS IN SHACOB AND AIPH SYSTEMS

Table 16 contains all the screening factors for the "A" bulk materials found in the scenarios investigated. Since none of the raw material criteria were exceeded, the supply of raw materials does not constrain bulk material supplies. We need concern ourselves only with the bulk material criteria in Table 16.

Iron, Stee 1

In five scenarios, steel exceeds the threshold level from cost $\left(\$ 15 / \mathrm{m}^{2}\right)$ only. All other factors are well below the threshold and shall not concern us. The quantity of supplies will be adequate. Steel cost varies from $\$ 23$ to $\$ 59 / \mathrm{m}^{2}$ ( $\$ 2.14$ to $\left.\$ 5.48 / \mathrm{ft}^{2}\right)$, which is in the order of $10 \%$ of the total system installed cost. Doubling the cost of steel decidedly affects economic viability of the system, and for this reason alone, steel represents a potential constraint to SHACOB and AIPH.

Fortunately, the steel industry is mature and competitive and prices have been relatively stable. However, if the present situation ceases to continue mitigating strategies will be necessary and could include:

?. Enter into long term supply contracts with favorable price agreements.

2. Minimize steel usage by more efficient mechanical design or by eliminating certain components such as storage tanks.

3. Have substitute materials ready for use when the relative costs become favorabie. 
Table 16. Screening Factors in Scenarios Where "A" Bulk Materials Were Found

\begin{tabular}{|c|c|c|c|c|c|c|c|}
\hline Factors & $\begin{array}{l}\text { Material } \\
\text { Usage Mt. }\end{array}$ & $\begin{array}{c}\text { Percent } \\
\text { Supplied as } \\
\text { By-Produce }\end{array}$ & $\begin{array}{c}\text { World Prodn } \\
\text { Growth Rate } \\
1976-2000 \\
\end{array}$ & $\begin{array}{c}\text { Solar's } \% \\
\text { of World } \\
\text { Consumption }\end{array}$ & $\begin{array}{l}\% \text { from } \\
\text { Largest } \\
\text { Country }\end{array}$ & $\begin{array}{c}\text { Cost per } \\
\text { Unit } \\
\text { Output } \pm / S M \\
\end{array}$ & $\begin{array}{c}\text { Net } \\
\text { Percent } \\
\text { Imported }\end{array}$ \\
\hline Threshold Levels & $-\cdots$ & 58 & $18 \% / y r$ & 18 & 35 & 15 & 50 \\
\hline \multicolumn{8}{|l|}{ Scenario $(\mathrm{a})$} \\
\hline \multicolumn{8}{|l|}{ Iron, Steel } \\
\hline Amer Heliothermal H \& HW & $33,379,590$ & 1 & 3 & 0 & 16 & $23^{(a)}$ & 10 \\
\hline RayPak-HT + Cool + HW & $51,070,088$ & 1 & 3 & 1 & 16 & $35^{(\mathrm{a})}$ & 10 \\
\hline Chamberlain Lumber Kiln & $85,477,352$ & 1 & 3 & 1 & 16 & $59^{(\mathrm{a})}$ & 10 \\
\hline A]PH-Mixed Systems & $34,375,328$ & 1 & 3 & 0 & 16 & $24^{(\mathrm{a})}$ & 10 \\
\hline A]PH-Mixed-109 $\mathrm{m}^{2}$ & $68,750,656$ & 1 & 3 & 1 & 16 & $24^{(a)}$ & 10 \\
\hline \multicolumn{8}{|l|}{ Glass, Soda Lime } \\
\hline SHACOB-Mixed- $10^{9} \mathrm{~m}^{2}$ & $13,299,237$ & 0 & 3 & ${ }_{10}^{(a)}$ & 5 & 4 & 5 \\
\hline \multicolumn{8}{|l|}{ PVF (Polyvinyl Fluoride) } \\
\hline KTA \& Ecoxol Heat Pump Sys & 75,060 & 0 & 8 & $18^{(a)}$ & 5 & 32 & 5 \\
\hline
\end{tabular}

a. All scenarios at $500 \times 10^{6} \mathrm{~m}^{2}$ unless otherwise noted. 
The high iron and steel costs shown in Table 16 are due to the use of iron and steel in all three principal components - piping, storage vessels, and collectors. For a more detailed description of steel uses, refer to the individual system characterizations in Appendix B.

Soda Lime Glass and Polyvinyl Fluoride

In the mixed design $S H A C O B$ Scenario of one billion $\mathrm{m}^{2}$ by the year 2000 , $10 \%$ of the world's consumption of soda lime glass is consumed by SHACOB systems (Table 16). All other criteria are well below the threshold levels. There are no raw material supply constraints to glass production. The projected production growth rate of $3 \%$ should be attained easily enough. Soda lime glass is used as a double glazing in seven of the SHACOB system designs, as a single glazing in one design, and as evacuated tubes in the remaining design.

Polyvinyl fluoride (PVF) single glazing used in one system deployed to 500 million $\mathrm{m}^{2}$ by the year 2000 will account for $18 \%$ of the world's consumption of fluorocarbons. All other criteria are well below the threshold levels, except for production growth rate at $8 \%$ which is modest for the plastics industry which has routinely expanded at rates of $10 \%$ to $15 \%$ in the past. No raw material constraints to PVF production were found in the raw material screening.

Both PVF and soda lime glass are used solely for collector glazings in SHACOB and AIPH systems. Since both of these "A" materials show up because of a potential for solar to drive the market, we recommend that future price trends in these industries be watched closely and that surges in demand due to solar are prevented since these could easily cause prices to rise sufficiently to affect the economics of the designs. Both materials are produced by a limited number of responsible manufacturers. The capital requirements of both industries 
are considerable. And long term production contracts will materially ease the prospects of any unexpected price increases.

The situation for the other popular glazing alternatives is similar, as shown in Table 17. Table 17 also shows the amount of each glazing material that could be installed by the year 2000 without exceeding $10 \%$ of the world's consumption in any single year. For the exponential growth rate used in this study, the largest single year installation is in the year 2000 and is equal to $15 \%$ of the total installations. Under these assumptions, a total of nearly 6.2 billion $\mathrm{m}^{2}$ of single glazing is possible. Over half of that is FRP polyester. Clearly, solar collectors represent a large market potential for the suppliers of glazing materials. Long term production contracts would be mutually beneficial to both suppliers and users of glazing materials. "B" MATERIALS IN SHACOB AND AIPH SYSTEMS

"B" materials in SHACOB and AIPH systems will be discussed jointly because the reasons for classifying them as " $B$ " materials are the same. Eleven bulk and fifteen raw materials were classified " $B$ " in various scenarios as previously shown in Tables 12, 13, 14, and 15.

The specific screening criteria exceeded by each " $B$ " bulk materials are given in Table 18. Only three criteria are involved. They say:

1. More than $50 \%$ of the supply comes as a byproduct whose production is limited by the production rate of the principal product, or

2. More than $35 \%$ is produced by a single foreign country, or

3. More than $50 \%$ of the U.S. supply is imported.

These factors pose no supply problem in the scenarios studied because in all cases the solar consumption as a percentage of world consumption and cost to solar are low. 


\section{TABLL 17. Some Glazing Material Alternatives}

\begin{tabular}{|c|c|c|c|c|}
\hline \multirow[b]{2}{*}{ Glazing Material } & \multirow[b]{2}{*}{$\begin{array}{c}\text { Typical } \\
\text { Thickness } \\
\text { Inches } \\
\end{array}$} & \multicolumn{2}{|c|}{$\begin{array}{c}\text { One Billion } \mathrm{m}^{2} \\
\text { Installed by Year } 2000\end{array}$} & \multirow{2}{*}{$\begin{array}{l}\text { Area With } \\
\text { Solar Limited to } \\
\text { of Consumption } \\
\text { In Year } 2000 \\
109 \mathrm{~m}^{2} \\
\end{array}$} \\
\hline & & $\begin{array}{c}\text { Material } \\
\text { Usage } \\
10^{6} \text { MT } \\
\end{array}$ & $\begin{array}{l}\text { Solars \% } \\
\text { of World } \\
\text { Consumption } \\
\end{array}$ & \\
\hline PVF $(\text { Tedlar) })^{(a)}$ & .004 & .153 & 30 & .26 \\
\hline $\operatorname{FEP}\left(\right.$ Teflon) ${ }^{(a)}$ & .002 & .109 & 19 & .48 \\
\hline Glass & .125 & 7.94 & 6 & 1.68 \\
\hline $\begin{array}{l}\text { FRP Polyester } \\
\text { (70 w/o Polyester) }\end{array}$ & .035 & .994 & 3 & 3.52 \\
\hline Polycarbonate & .0625 & 1.91 & 34 & .22 \\
\hline TOTAL & & & & $\overline{6.16}$ \\
\hline
\end{tabular}

(a) A registered trademark of E.I. DuPont Co. 
TABLE 18. CRITERIA EXCEEDED BY "B" BULK MATERIALS (a) IN SHACOB AND AIPH SYSTEMS

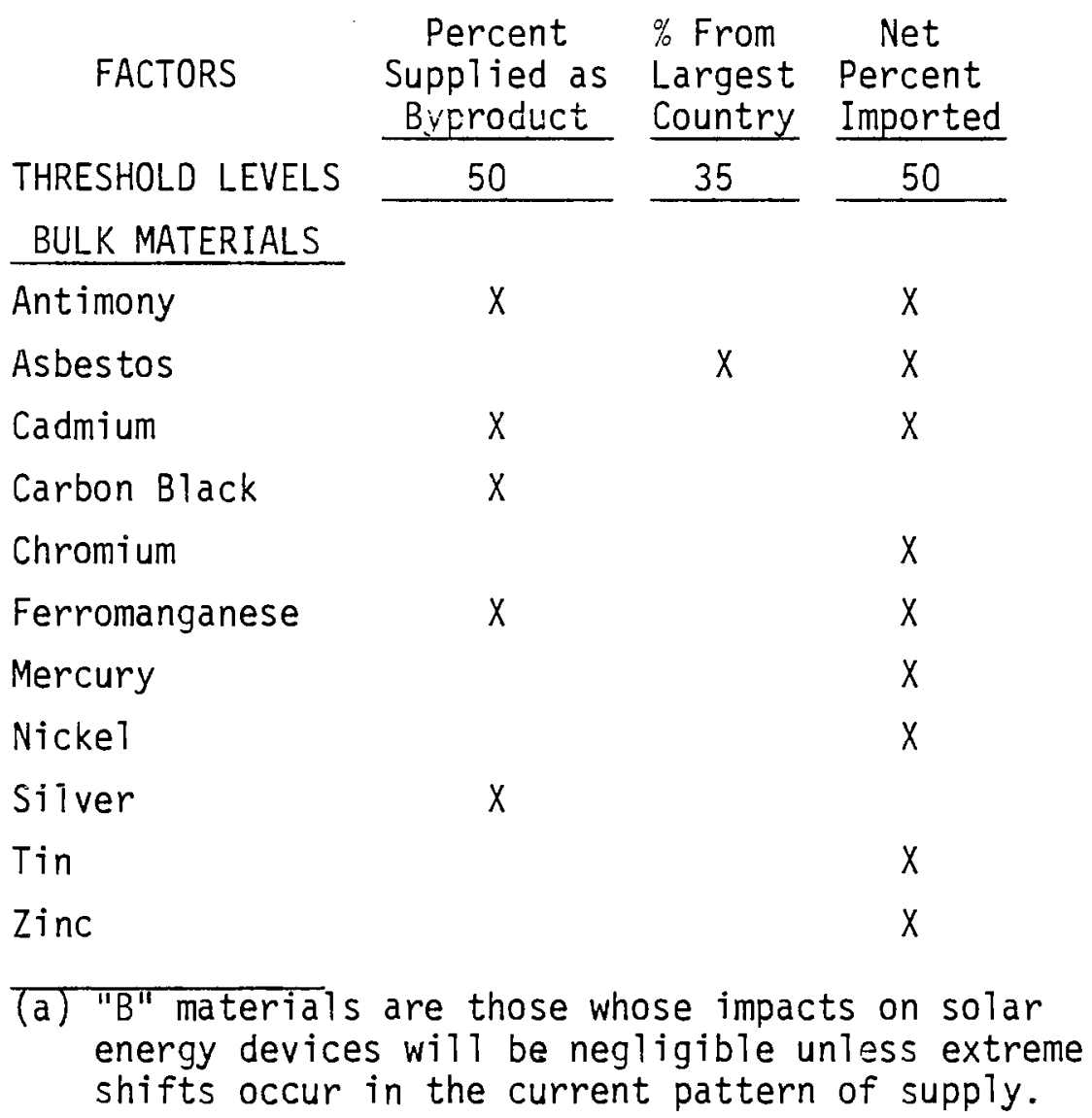


Since the solar share of world consumption is low, the material will be available in the quantities required by solar even if the total U.S. supply is limited severely by cartels, political action or decrease in production. Under conditions of limited supply and hence, increased competition for the material, increased prices are anticipated. Even then a large price increase would be required to push the already low materials cost to solar $\left(\cos t / \mathrm{m}^{2}\right)$ to an unacceptable level and force the use of substitutes.

The same type of reasoning was used in classifying the "B" raw materials. The specific criteria exceeded by each " $B$ " raw material is shown in Table 19. Two criteria are identical to those just discussed - Net Percent Imported and Percent From Largest Foreign Country. The effect of these two raw material factors on solar is minimal because the solar use and cost to solar for each of these raw materials is small (circa $1 \%$ and $\$ 1 / \mathrm{m}^{2}$ and less).

Exceeding the criteria for United States reserves and resources means either that more of the raw material will be imported in the future or that U.S. reserves and resources will have to increase. Historically, reserves and resources have generally increased with time due to continued exploration, development, and improved technology or increased prices which shift previously uneconomic deposits into the reserve category. Whether or not U.S. reserves and resources increase, the raw materials will be available worldwide in sufficient amounts since the criteria for world reserves and resources were not exceeded. Again, supply disruptions will have little effect because solar usage and cost to solar are small for all these materials.

World production growth rate of $7 \%$ was exceeded by one material, lithium ore. Once again the small solar requirement will be satisfied even if the world 
TABLE 19. CRITERIA EXCEEDED BY "B" RAM MATERIALS (a) IN SHACOB AND AIPH SYSTEMS

\begin{tabular}{|c|c|c|c|c|c|}
\hline FACTORS & $\begin{array}{l}\% \text { U.S. } \\
\text { Reserves } \\
\text { Consumed } \\
\text { by } 2000 \\
\end{array}$ & $\begin{array}{l}\% \text { U.S. } \\
\text { Resources } \\
\text { Consumed } \\
\text { by } 2000 \\
\end{array}$ & $\begin{array}{l}\text { Net } \\
\text { Percent } \\
\text { Imported }\end{array}$ & $\begin{array}{l}\% \text { From } \\
\text { Largest } \\
\text { Country } \\
\text { Non-US } \\
\end{array}$ & $\begin{array}{l}\text { World } \\
\text { Production } \\
\text { Growth } \\
\text { Rate } \\
\end{array}$ \\
\hline ARESHOLD LEVELS & 400 & 300 & 50 & 60 & $7 \% / Y r$ \\
\hline
\end{tabular}

RAW MATERIALS

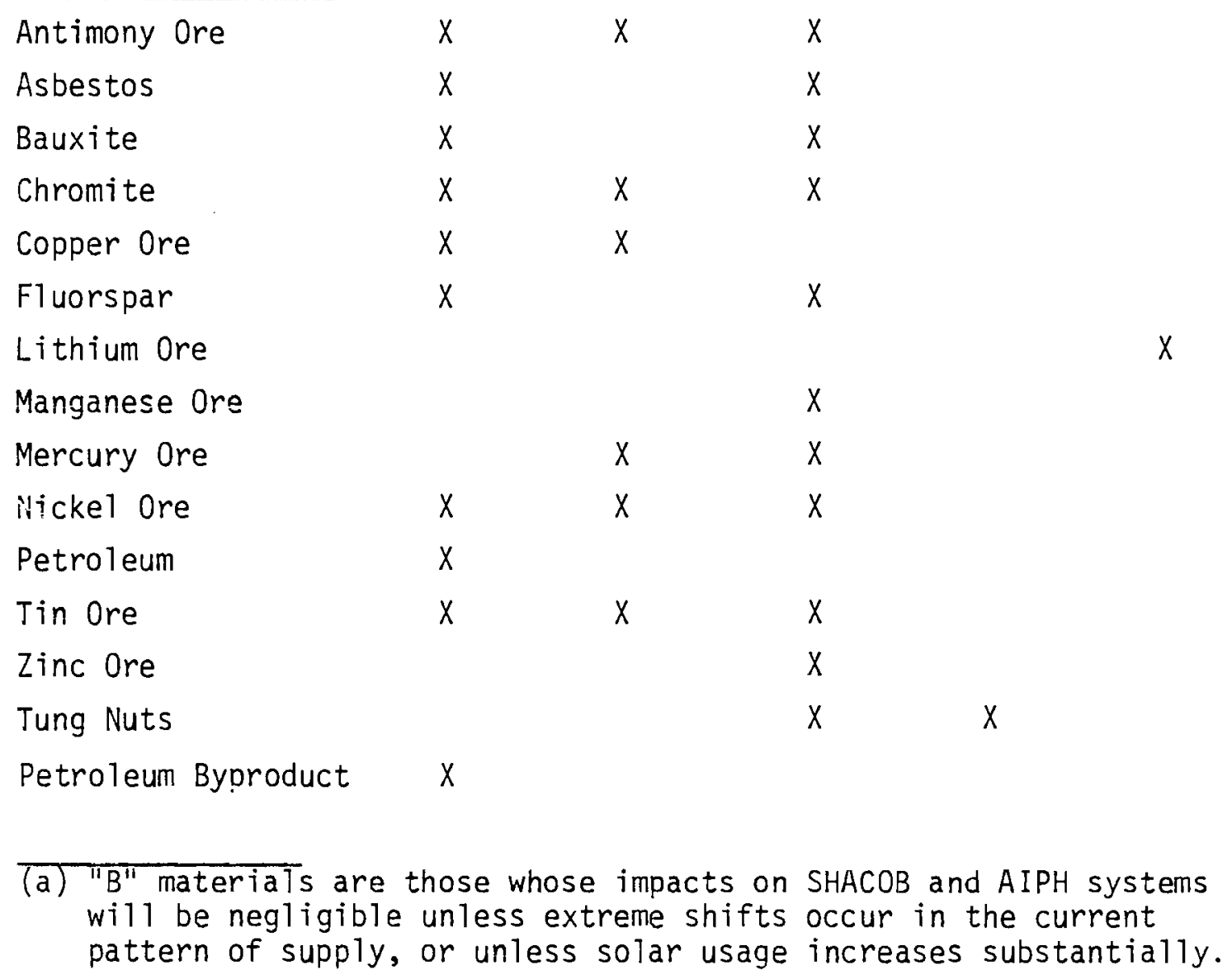


production rate does not meet demand. Higher prices resulting from demand exceeding supply will not raise the already low cost to solar significantly. Since solar's percent of world consumption is low, it follows that the growth rate is high because of projected non-solar demands for the raw material. In other words, the production growth rate is largely independent of solar demand.

Taking a broader perspective, one sees that all the other criteria exceeded by " $B$ " materials, both bulk and raw, are largely independent of solar demand. They are exogenous criteria. Any material in a solar device that exceeds at least one of the exogenous criteria is always classed as a "B" material or higher. So long as the material's share of world consumption or its cost to the solar device are low, it remains a "B" material.

If solar usage of a "B" material increases enough, either one or both of the endogenous criteria (solar's share of world consumption and the cost to solar) will be exceeded. When these endogenous criteria are exceeded, the material is classified as an "A" material. In that situation, exogenous factors could significantly affect the availability and cost of the material to solar.

In summary, materials which are present in a solar device and exceed any of the exogenous criteria are classified as " $B$ " materials so long as their use in the solar device is small. Their impacts on SHACOB and AIPH systems will be negligible - unless extreme shifts occur in the current pattern of supply, or unless solar usage increases sufficiently to put them into the "A" material category. 


\section{REFERENCES:}

1. Solar Collector System Engineering, Program ACSE 1, Scotch Programs, Box 430734, Miami, FL.

2. Klein, S. A., W. A. Beckman, and J. A. Duffie: A Design Procedure for Solar Heating Systems, Solar Energy, vol. 18, pp. 113, 1976.

3. Beckman, W. A., J. A. Duffie, and S. A. Klein: Simulation of Solar Heating Systems, "Applications of Solar Energy for Heating and Cooling a Building," Chap. 9, ASHRAE, New York, 1976.

4. Klein, S. A., W. A. Beckman, and J. A. Duffie: A Design Procedure for Solar Air Heating Systems, 1976 ISES American Sect. Conf., Winnipeg, Manitoba, August 15-20, 1976.

5. J. D. Balcomb, J. C. Hedstrom, R. D. McFarland, Passive Solar Heating of Buildings, Workshop on Solar Energy Applications, Associated Universities, Inc. June 27-July 31, 1977.

6. Fred Roach, Scott Noll, Shaul Ben-David, Larry Bickle, William Schulze, Prospects for Solar Energy: The Impact of the National Energy Plan, Los Alamos Scientific Laboratory, LA - 7064 - MS, December 1977.

7. J. W. Litchfield, R. L. Hatts, W. E. Gurwell, J. N. Hartley, C. H. Blocmster, A Methodology for Identifying Materials Constraints to Implementation of Solar Energy Technologies, Pacific Northwest Laboratories, PIIL-2717, JuTy 1978.

8. S. D. Rosier, D. K. Davis, W. E. Gurwe11, T. P. Harrington, T. A. Nelson, S. A. Smith, R. L. Watts, Operating Manual and Data Base for the Critical llaterials Assessment Program (CMAP), Pacific Northwest Laboratory, PNL- , September 1978.

9. Solar Energy - A Status Report, U.S. Department of Energy, D0E-ET-0062, June 1978, p. 41. 

APPENDIX A

ACTUAL COMPUTER RUNS OF BULK AND RA!! MATERIAL SCREENING FACTORS

$\underline{\text { Page }}$

SHACOB and AIPH System Identifications

A-1

Screening Factors

Design

Number

SHACOB

25

26

27

28

29

30

31

32

33

$\underline{\text { AIPH }}$

40

41

42

SHACOB

AIPH
Short Title

SUNWORKS RES HW

$A-2$

SOLARON-RES HT

SOLARDN-RES HT + HW

AMER HELIOTHERMAL $\mathrm{H}+\mathrm{HW}$

KTA AND ECOSOL HEAT PUMP SY

RAYPAK - HT + COOL + HW

TROMBE WALL CONCRETE

TROMBE WALLWWATER

DIRECT GAIN MASONRY WALL

A-4

A-6

A-8

A-10

A-12

A-14

A-15

A-18

A-20

A-22

A-24

HONEYWELL CONCENTRATING

500 MILLION $M^{2}$ SCENARIO

BILLION $M^{2}$ SCENARIO

500 MILLION $\mathrm{H}^{2}$ SCENARIO

BILLION $M^{2}$ SCENARIO 
Design

Number

SHACOB

25

SUNWORKS RES HW

SOLARON-RES HT

SOLARON-RES HT $\div$ HW

AMER HEL IOTHERMAL $\mathrm{H}+\mathrm{HW}$

KTA AND ECOSOL HEAT PUMP SY

30

RAYPAK - HT + COOL + HW

31 TROMBE WALL CONCRETE

I 32 TROMBE WALL WATER

33 DIRECT GAIN MASONRY WALL

$\underline{\text { AIPH }}$

40 LLL SOLAR POND

41 CHAMBERLAIN - LUMBER KILN

42 HONEYWELL CONCENTRATING
Full Title

DOMESTIC HOT WATER-SUNWORKS COLLECTOR

SPACE HEATING - SOLARON SYSTEM

SPACE HEATING AND DOMESTIC HOT WATER - SOLARON

SPACE HEATING AND DOMESTIC HOT WATER - AMERICAN HELIOTHERMAL

SPACE HEATING AND DOMESTIC HOT WATER - KTA AND ECOSOL HEAT PUMP SYSTEM

SPACE HEATING AND COOLING AND DOMESTIC HOT WATER - RAYPAK COLLECTOR

PASSIVE SPACE HEATING - CONCRETE TROMBE WALL

PASSIVE SPACE HEATING - WATER-TANK TROMBE WALL

PASSIVE SPACE HEATING - DIRECT GAIN, MASONRY WALLS

PROCESS HOT WATER, URANIUM MILLING - LLL SOLAR POND

PROCESS HEAT, LUMBER KILN - CHAMBERLAIN COLLECTORS

PROCESS STEAM, TEXTILE DRYING - HONEYWELL CONCENTRATING COLLECTORS 
STI Fi: ELTHETL:

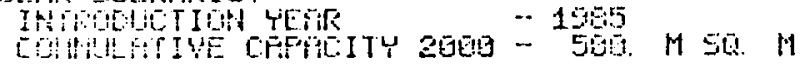

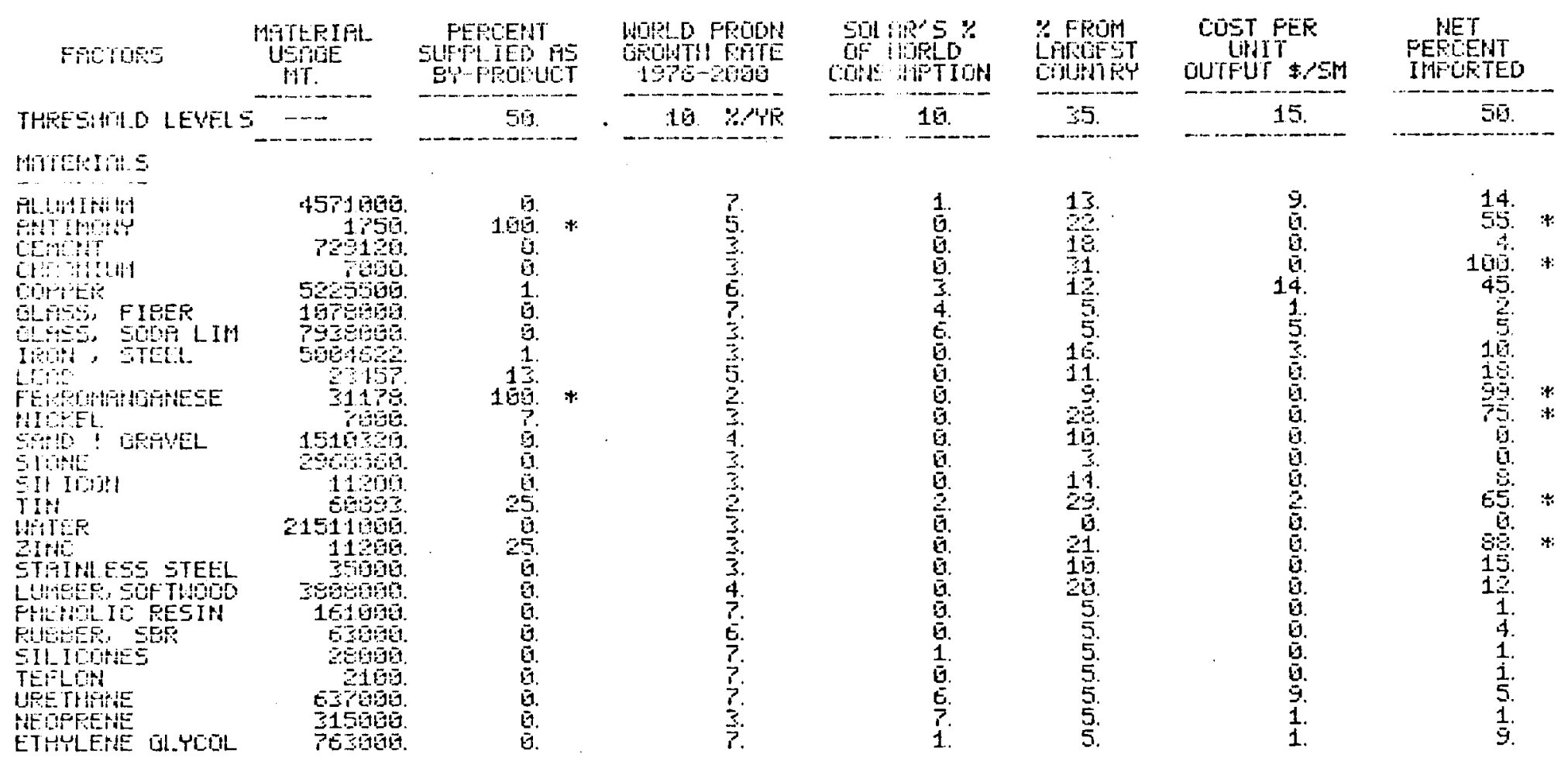




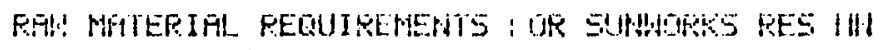

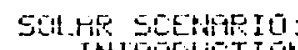

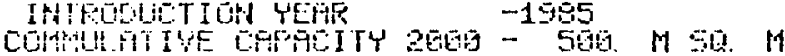

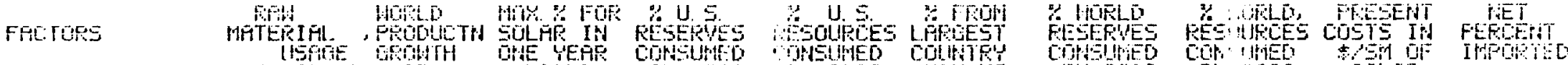
BV

THEESHDO LEYELS 300. 20.250 MTTESFL

hition

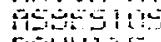
cting Eulitis

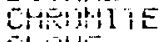
LLit:

IT TIH IIt!

D FELDE

Fldiestif

Gitent

ISOA toE

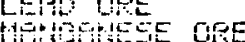

Hut

PITE

ITPEOH FISED

FETRELEH

591

EAtive

EIUAL

TII! in

2Ili Ge

LUTEE

SEF HATES

WHTEF

STEFid

LIYESTRE

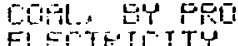

out. Bithot 2

$\begin{array}{rr}r & 7 \\ 101 \\ 0\end{array}$

$10 . \quad 403$

206.60.

300.

슬.

1.1.

$+\cdots$

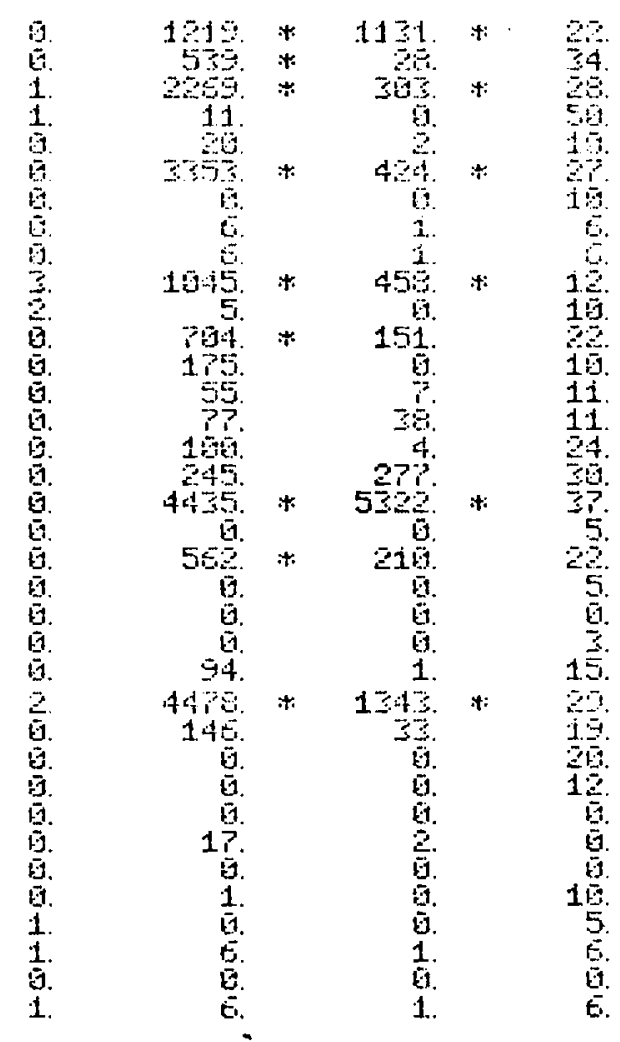

.

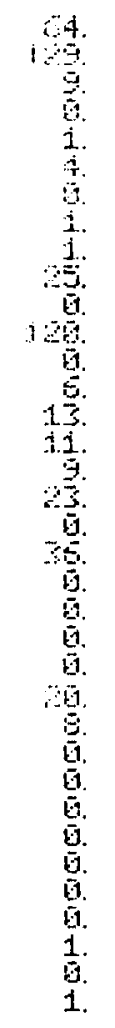

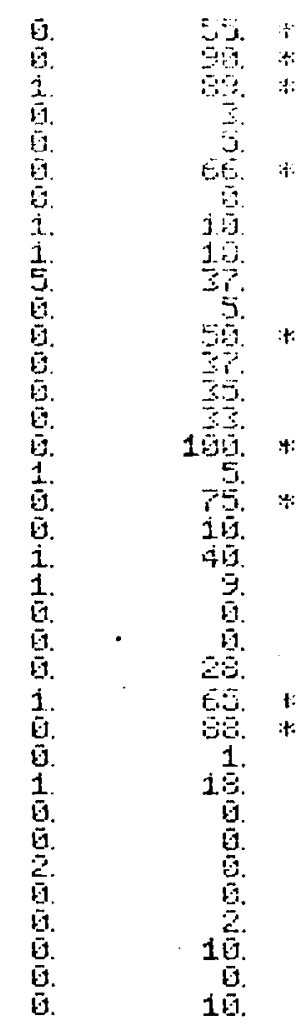




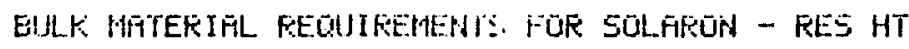

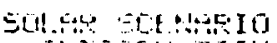

miand
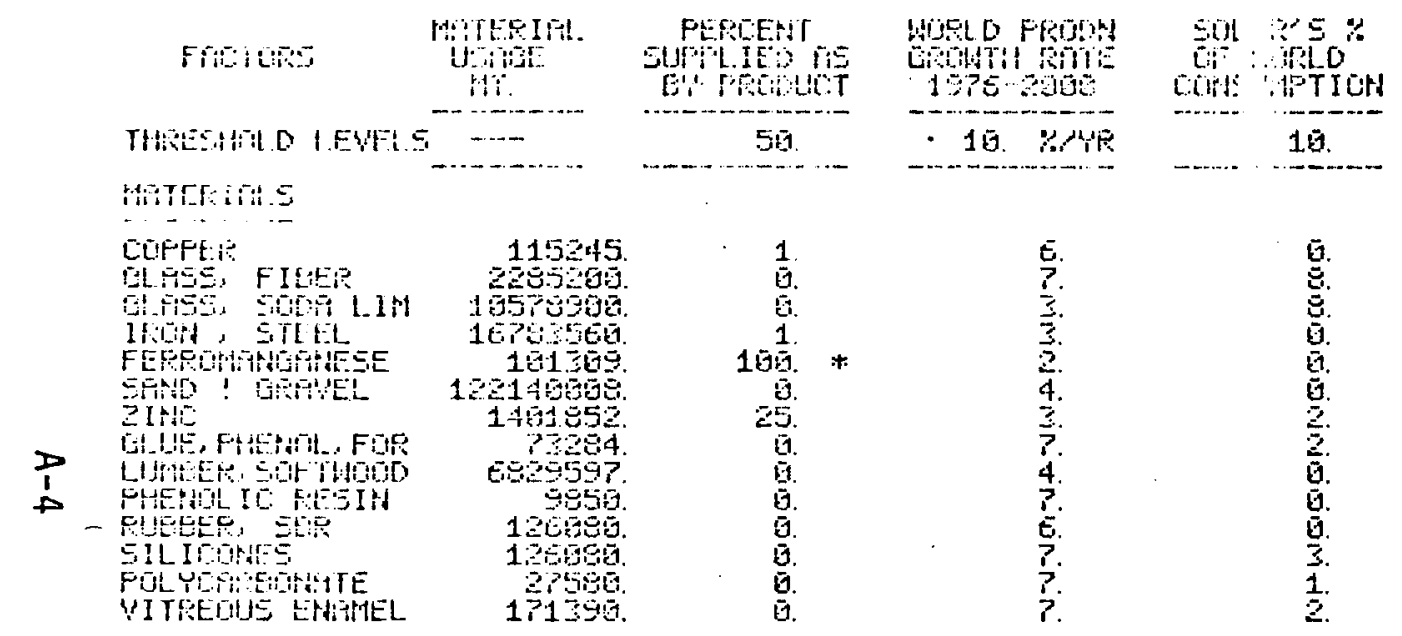

FFIN

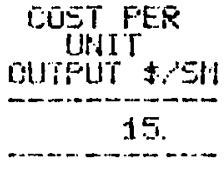

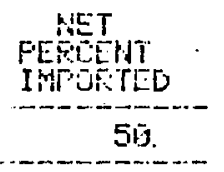

atidfitas

Fin Fil

15.

37

5ib.

Trebls LrHite

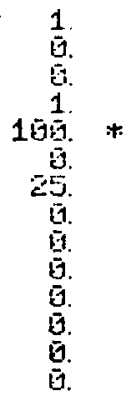

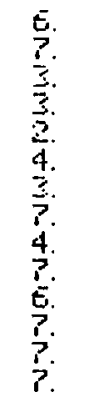

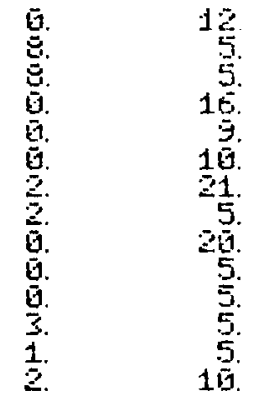

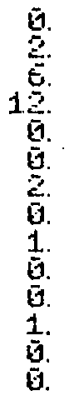

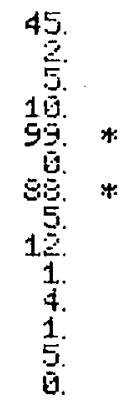


RMIU MATERIFIL REGUIFENENTS : UR SOLFEOUN - RES HT

SOt_file SCENAFIO:

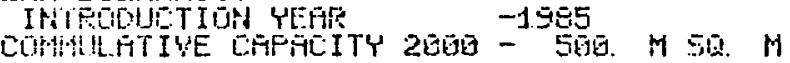

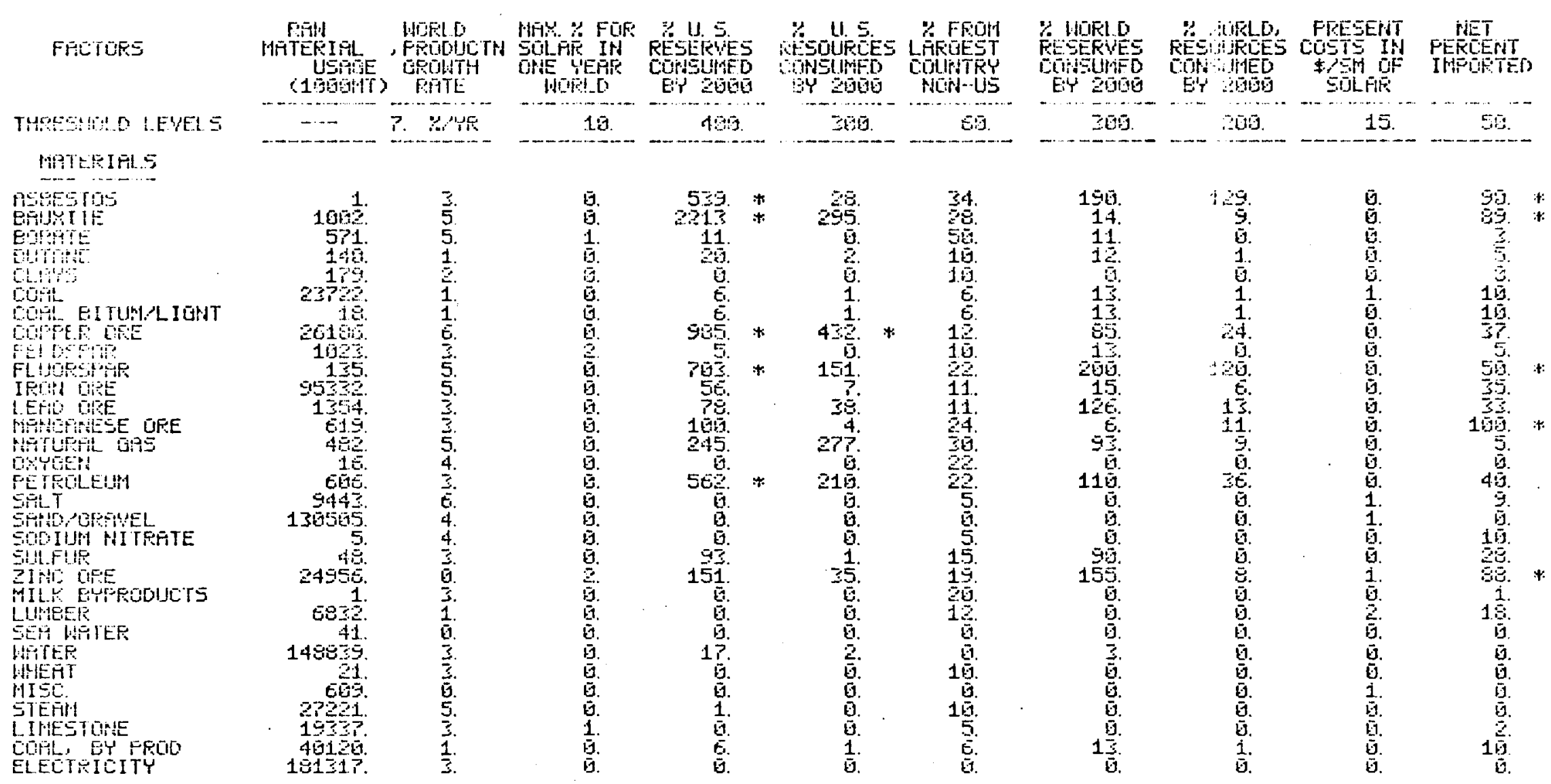




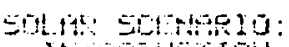

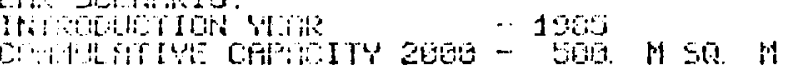

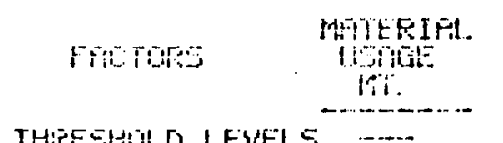
Miterelits

Fitument GHES FIER STELLIA

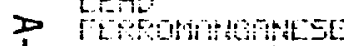

o stort: LFitiEL Tid

ETHI UIE lHEDO FOR Litrice = OF ThOO Futh lo toln PUDEE

SIL ICOPHE

FU YTABEOHATE

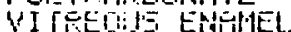

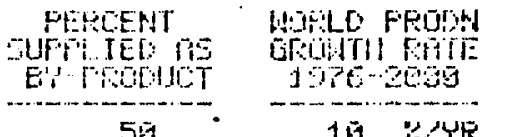

10. :ARR

$\frac{0.98}{10 .}$

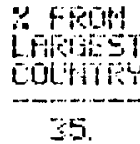

$\frac{\text { COST PEF }}{\text { LiHTT }}$

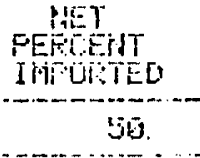

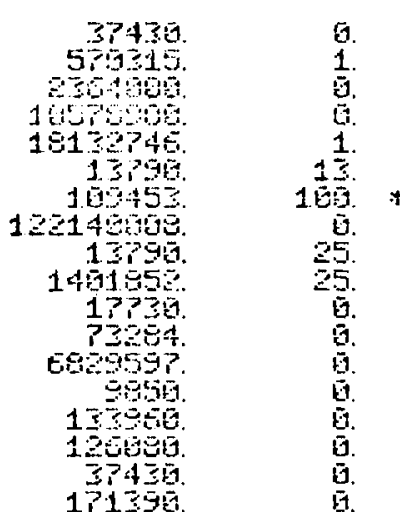

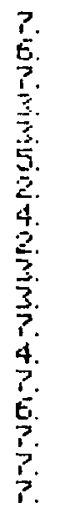

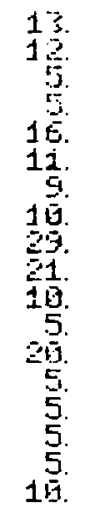

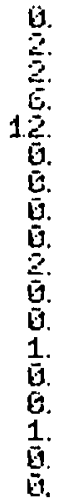

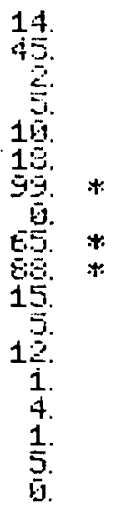




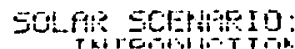

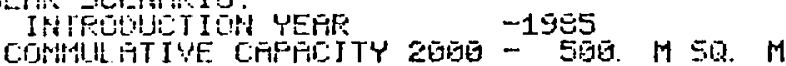

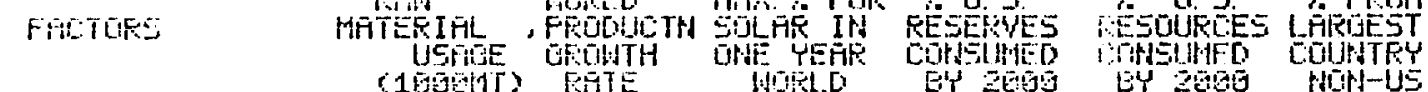

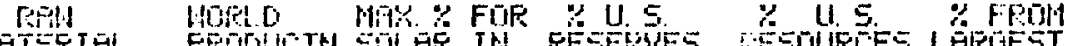

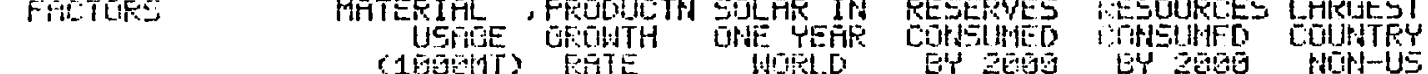

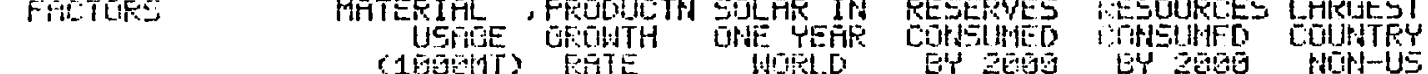

rHEESALD IEYAS ?. 24

$1 \bar{s}$ tis. 319. C.S.

$\because$ WOFLD 2 WOELO, FEESEHT PET

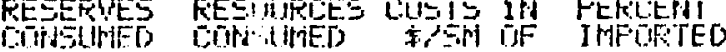
Ev MATLFIAL

HAF TIE

Eitedit:

Fin 1

6.1.

otos

ULL EITUHAILN

are

FE The

I FLUE

MED OHE

Mrinert. GHS

MICLA GE

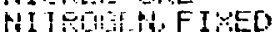

UPUEA

petcoleuth

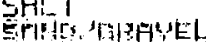

OOUTUW NITFTE

EULELE

$\operatorname{Tin}$ QRe

IIT

Liyet

SES HORE

WUETER

HI

STEiti

1 IVIES rIRE

EDGL EU FEGD

ELECTAICITY

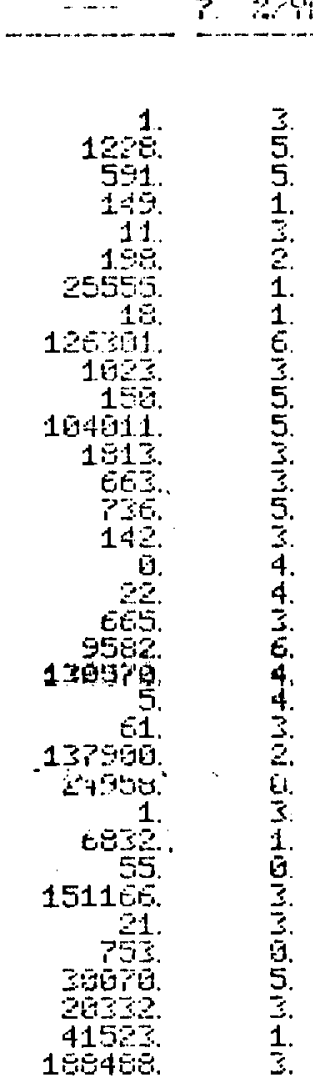

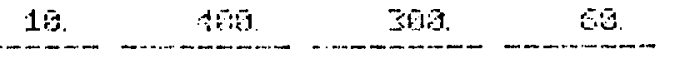

201.

$20 . \overline{1}$

is.

50.

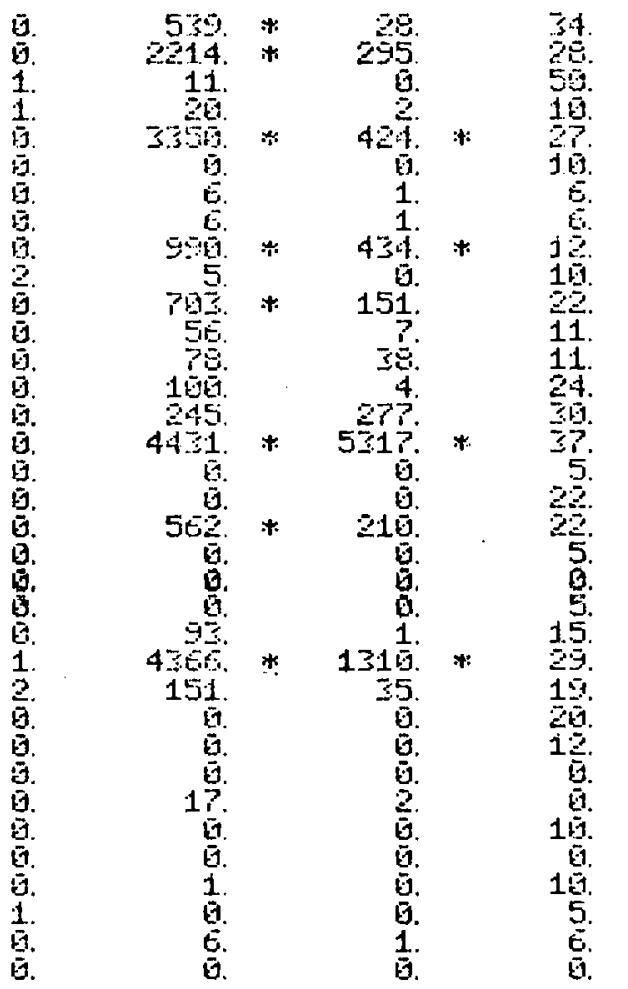

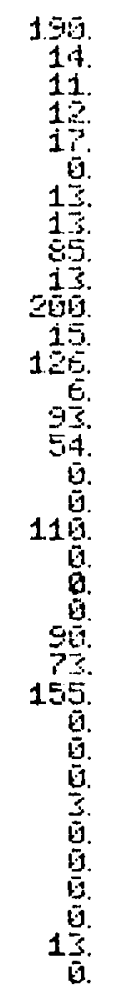

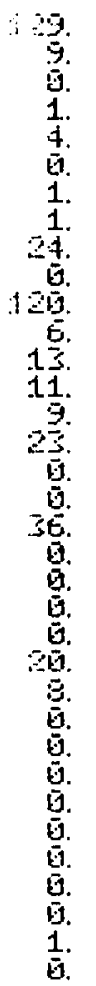

\begin{tabular}{|c|c|}
\hline 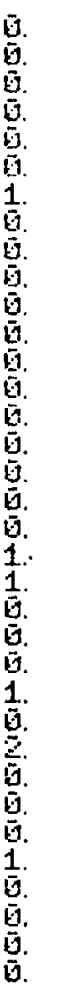 & 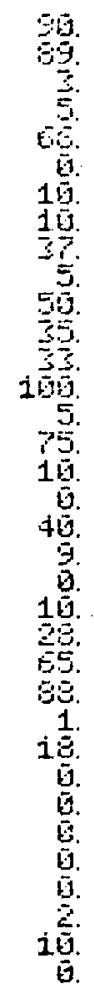 \\
\hline
\end{tabular}


EULK MATERIAL REQUIRENERTS. FUR GHAER HEL IUTHERHAOI $\mathrm{H}+\mathrm{HH}$

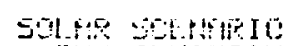

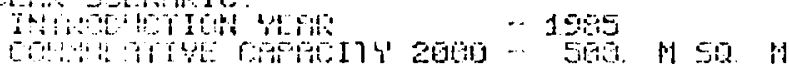

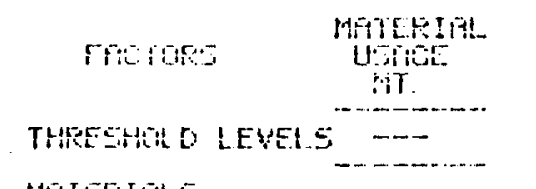

\begin{tabular}{|c|c|}
\hline 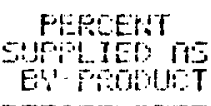 & 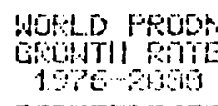 \\
\hline $5 \%$ & 10. : \\
\hline
\end{tabular}
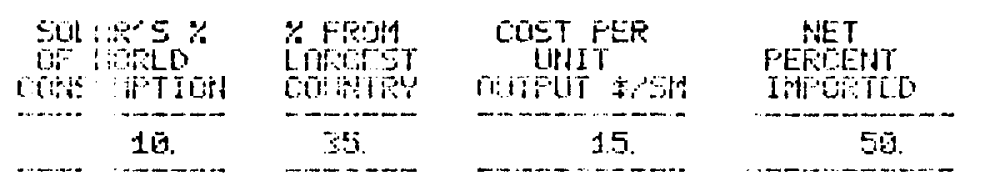

Miteren:

Fitimints

DOFER

GLES Foe

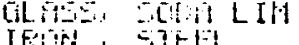

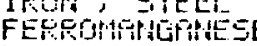

IISTEE

2I:I0;

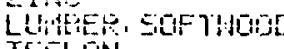

hilin?

NEDFtitis

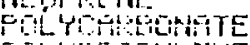

YITHEHS EHTHEL

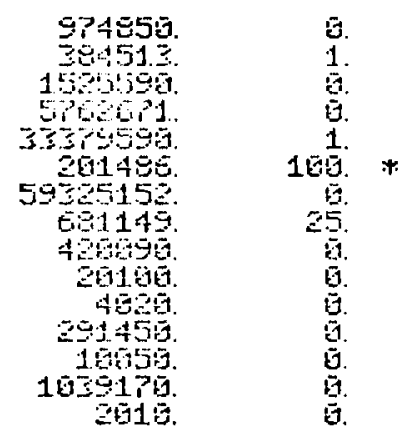

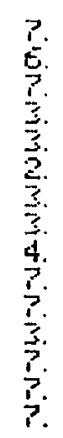

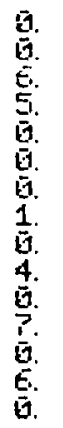

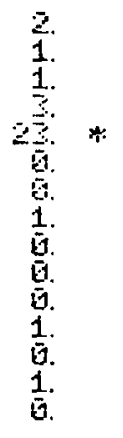

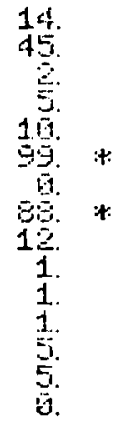


RITH MATEFIAL REQUIREREMTS : OR AMER HELIOTHEFHATL HHHJ

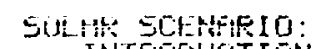

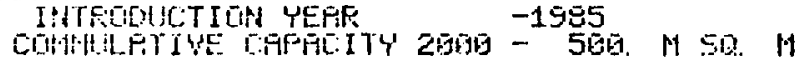

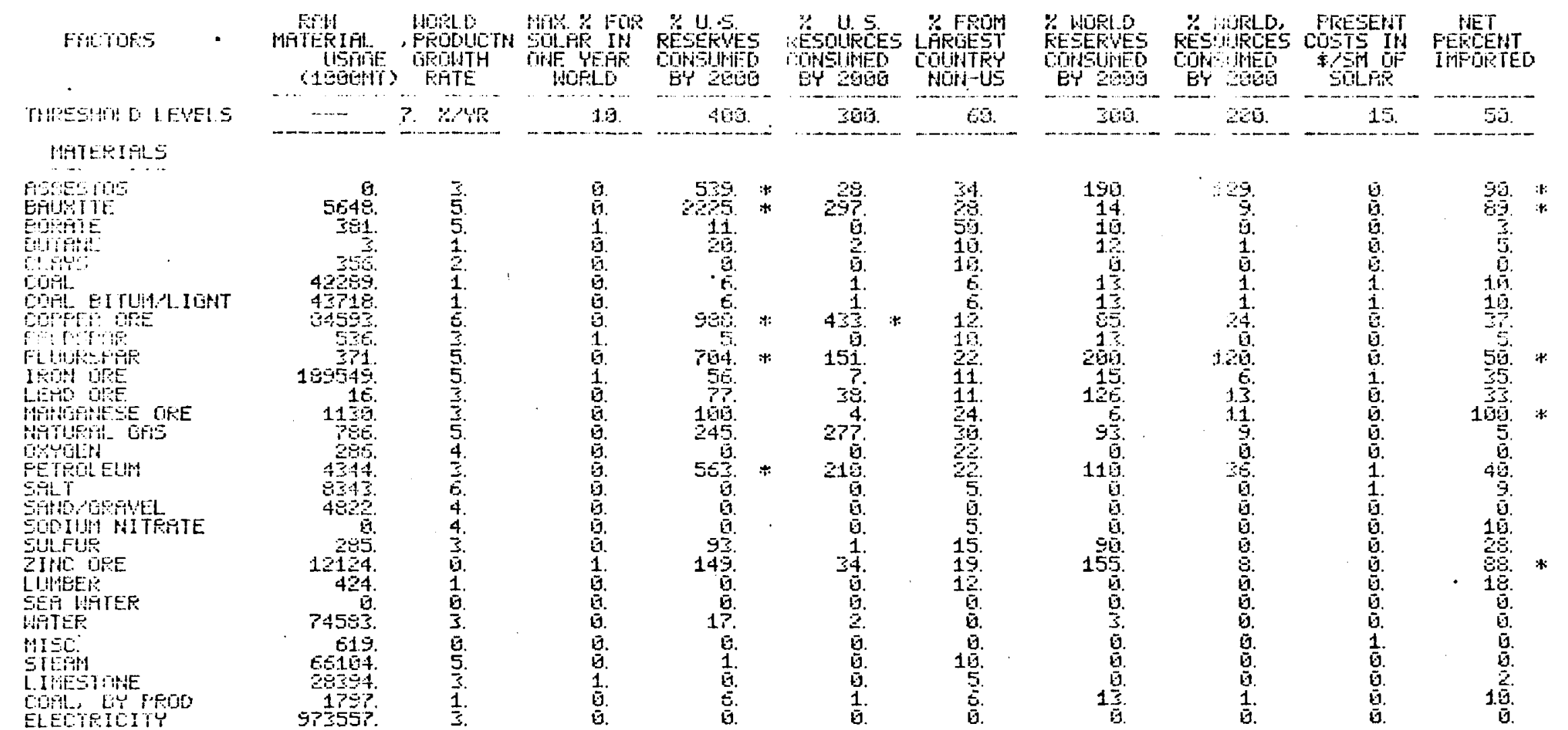




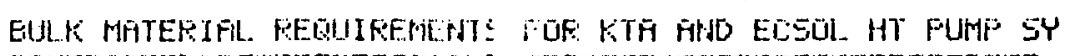

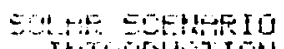

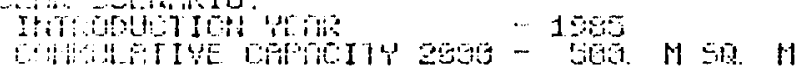

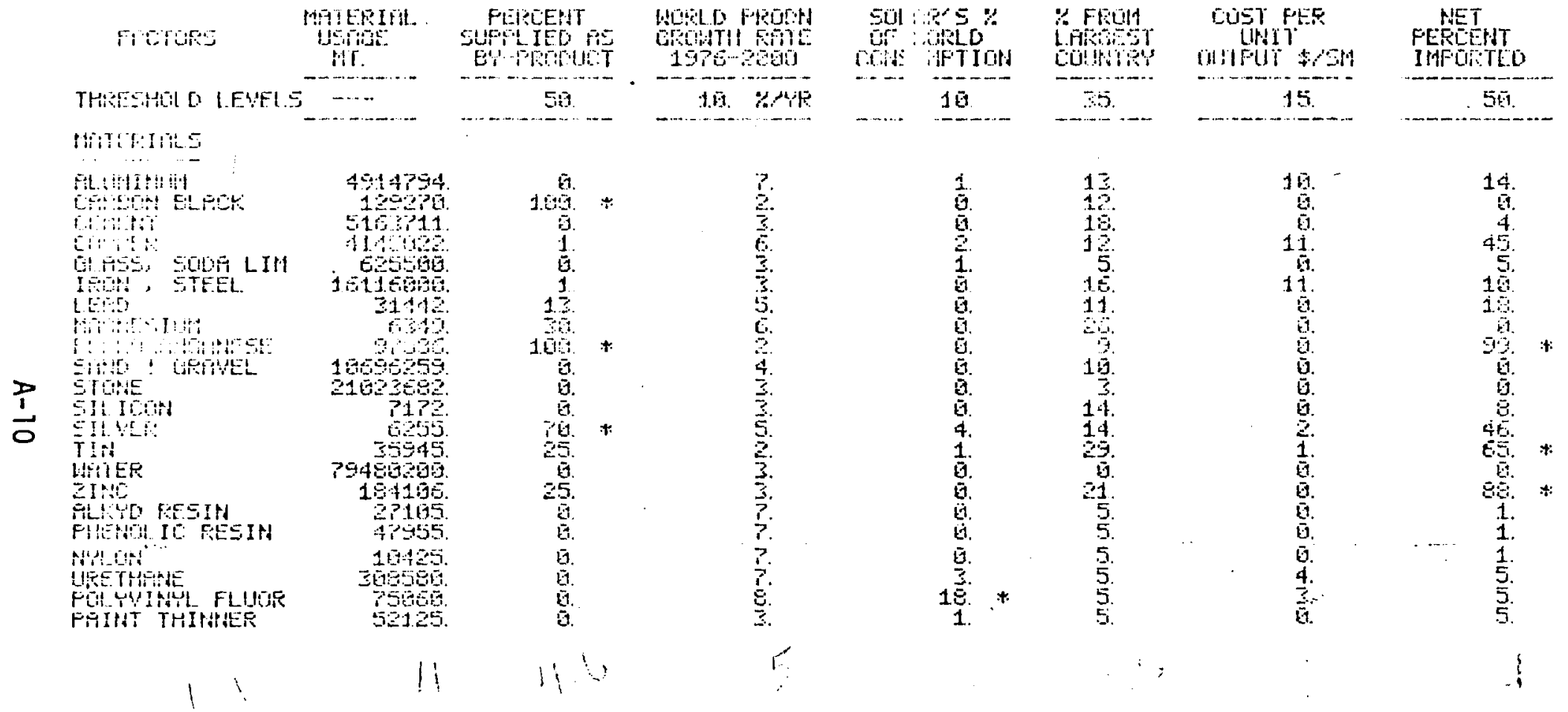




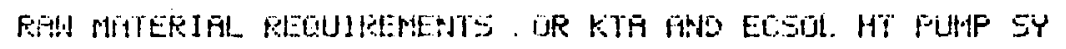

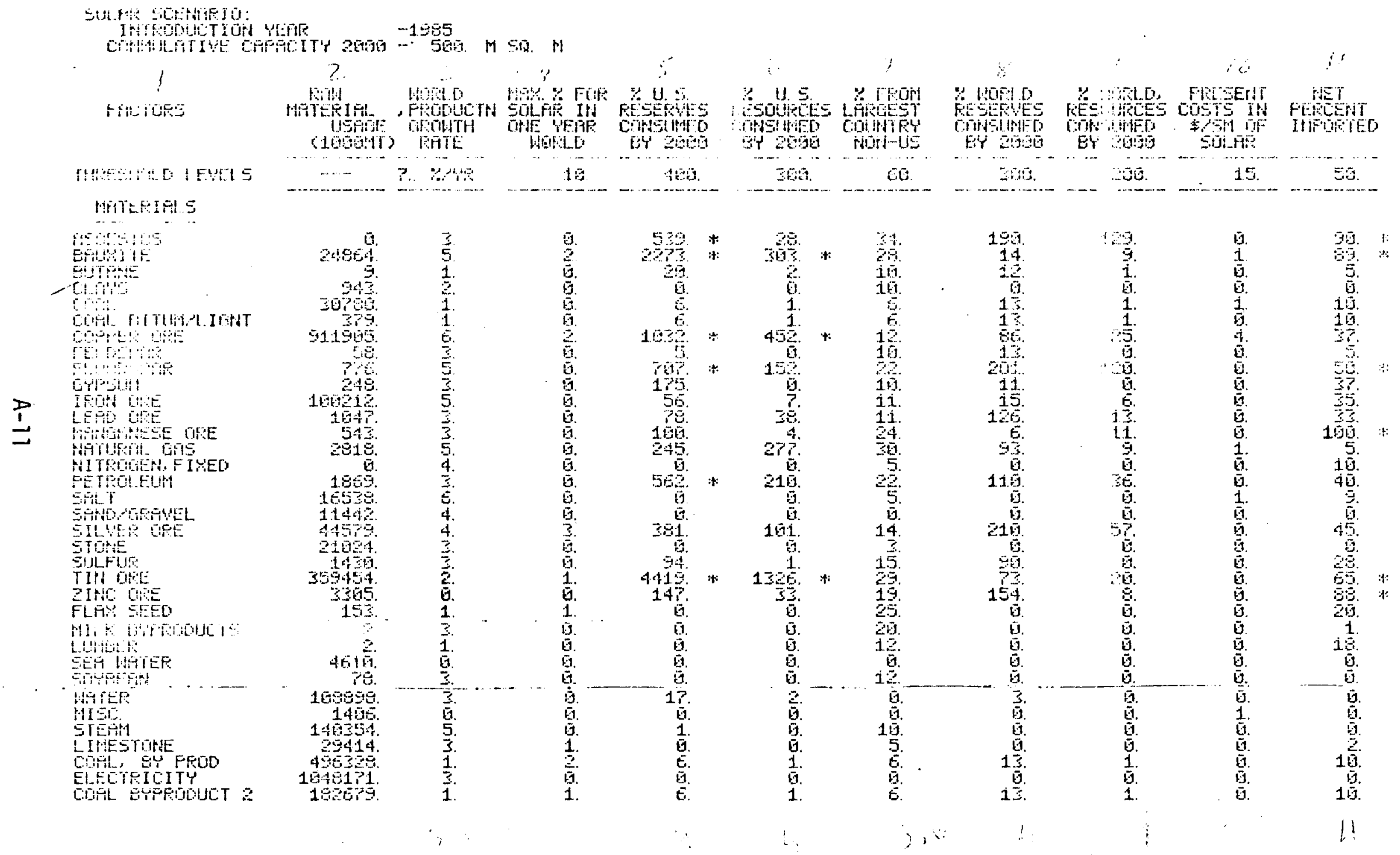




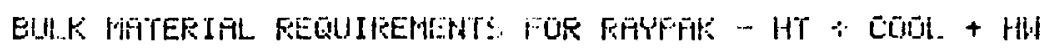

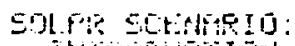

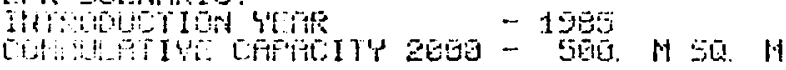

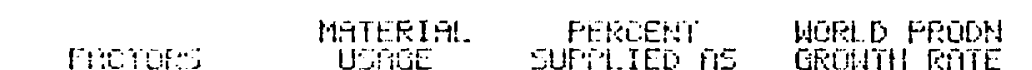

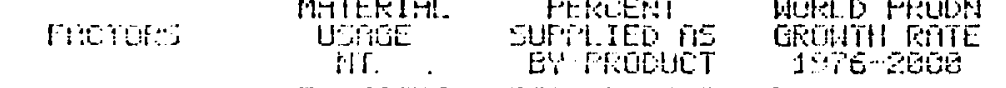

THEESHOH LEVELS

ATIT:CIILS

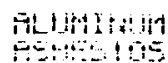

Hat

entio

CHAdt!lt

of Fit?

a

Itist

(C) STE

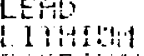

HOHWEE

Mis

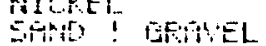

aline

Bited

IILYE

TIH

IT

STHIPULSS STEEL

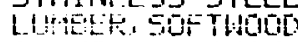

FHItHI IO FESIM

FU FU⿴囗十丁

SIL IORES

TEFLEM

COTTH FIERS

UAT F IELES

Fictith $T$

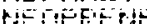

EruUtare GLYOLL

POL YETHULE

Fon

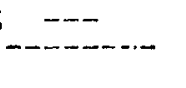

$5 \overline{1}$

iD. MT

of :

Cont ilotIan

Prom COAGEST

LUST FER

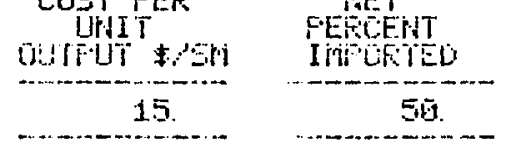

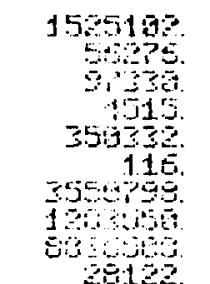

5161965

5164058
11685

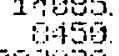

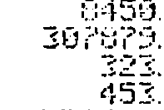

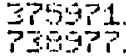

$359 ?$.
589
494
-5150

16019

4135

17. 405

20195

$14+18$

290

3040
50

205

1354569

$4 ?=?$

450
2640.
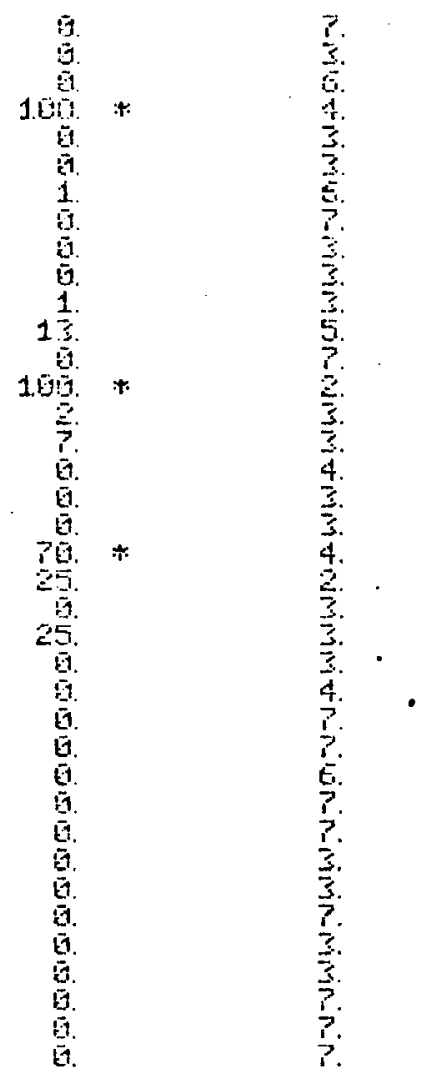

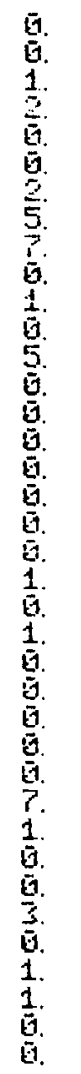

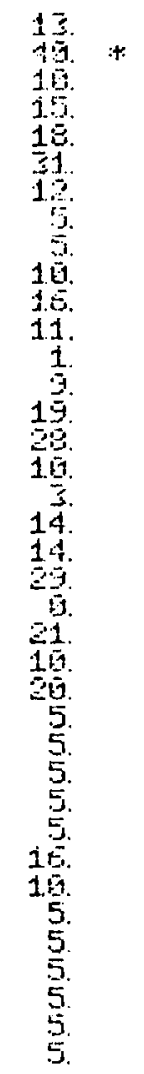

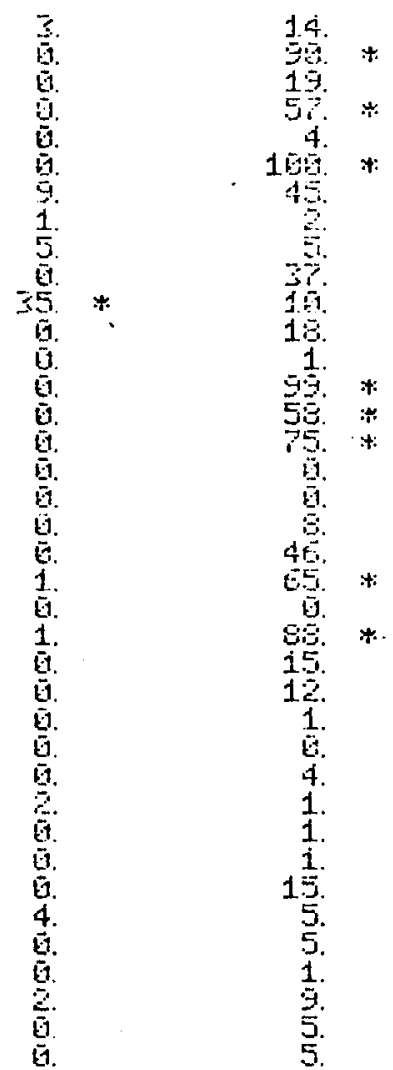




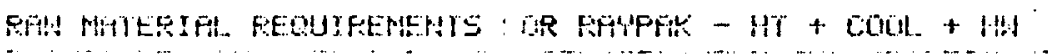

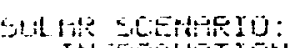

CHAH

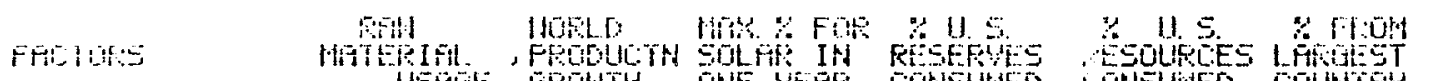

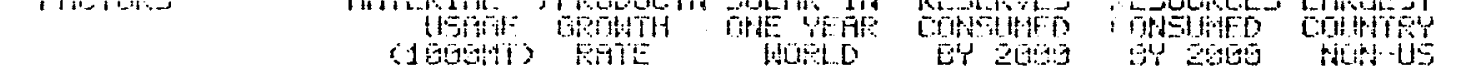

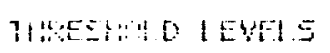
AHTLE

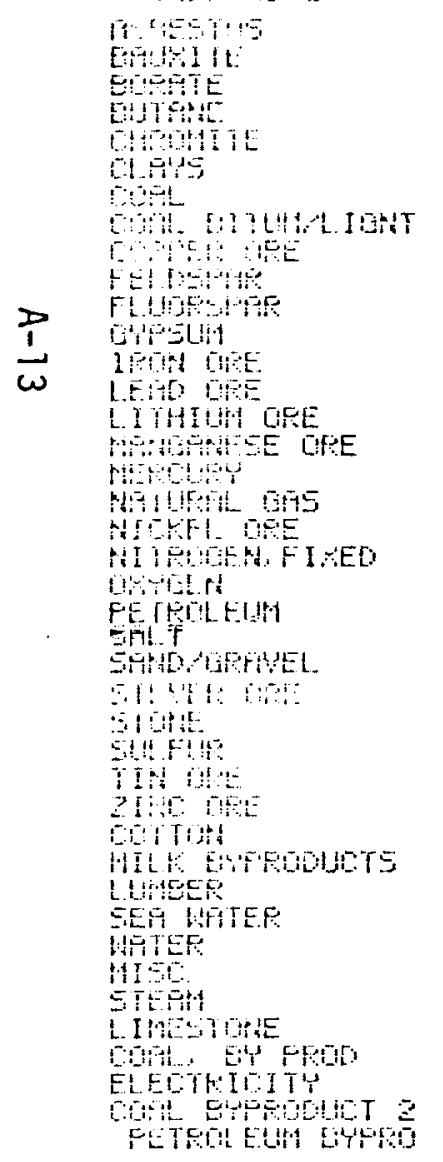

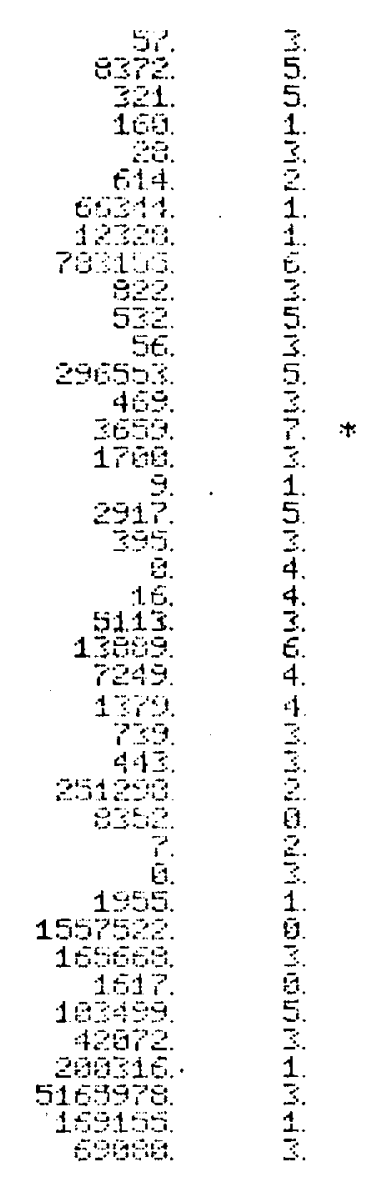

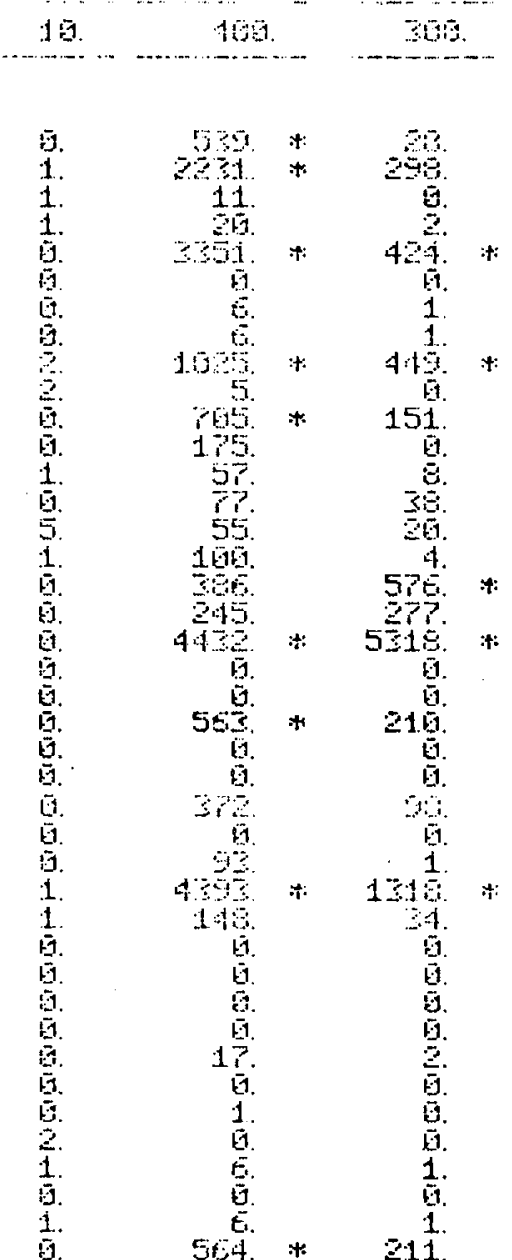

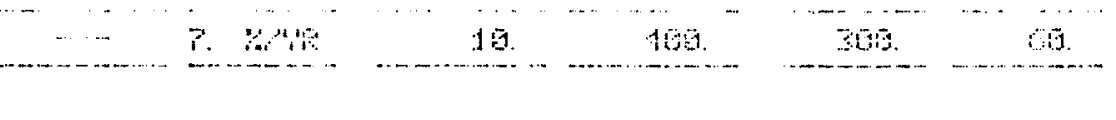

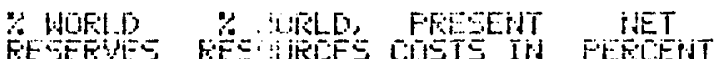
FESFES RE of

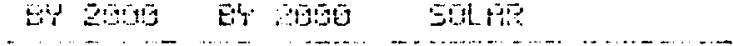

30

.16. 50. 
ELLK MATERIFIL REQUIREMENT: FOR TRÜHE WFILL CUNGRETE

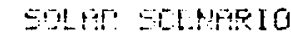

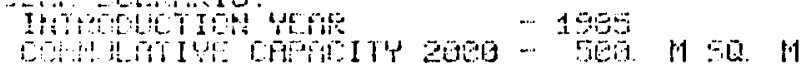

\begin{tabular}{|c|c|c|c|c|c|c|c|}
\hline 170.765 & 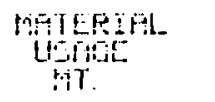 & $\begin{array}{l}\text { FEPCERT } \\
\text { SUTi } \\
\text { E' }\end{array}$ & wodrat & gon & 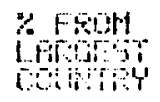 & 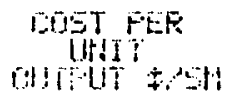 & $\begin{array}{l}\text { MET } \\
\text { FEECHT } \\
\text { IHETSE }\end{array}$ \\
\hline THAEESARLO LEYELS & $\equiv-\cdots$ & 50. & 15. 24 & 10. & 35 & 15. & 50. \\
\hline ATERTLS & & & & & & & \\
\hline 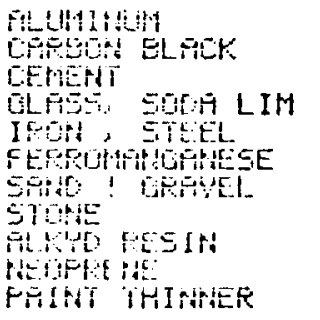 & 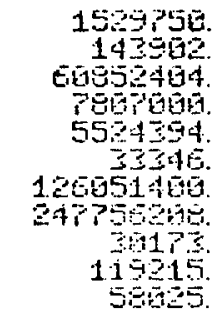 & 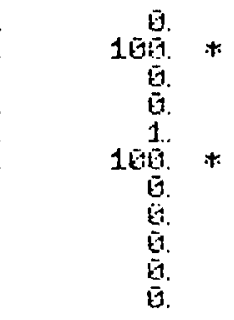 & 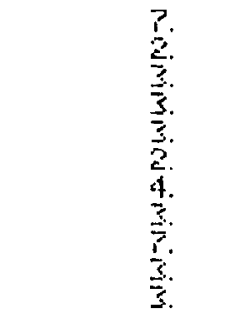 & $\begin{array}{l}5 . \\
5 . \\
1 . \\
6 . \\
0 . \\
0 . \\
0 . \\
0 . \\
\frac{6}{3} . \\
1 .\end{array}$ & 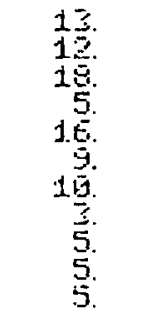 & 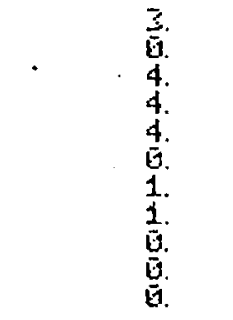 & 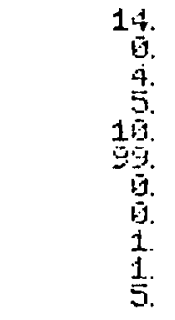 \\
\hline
\end{tabular}

$\frac{7}{1}$ 


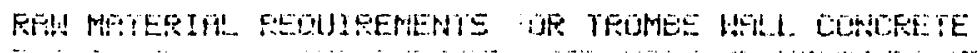

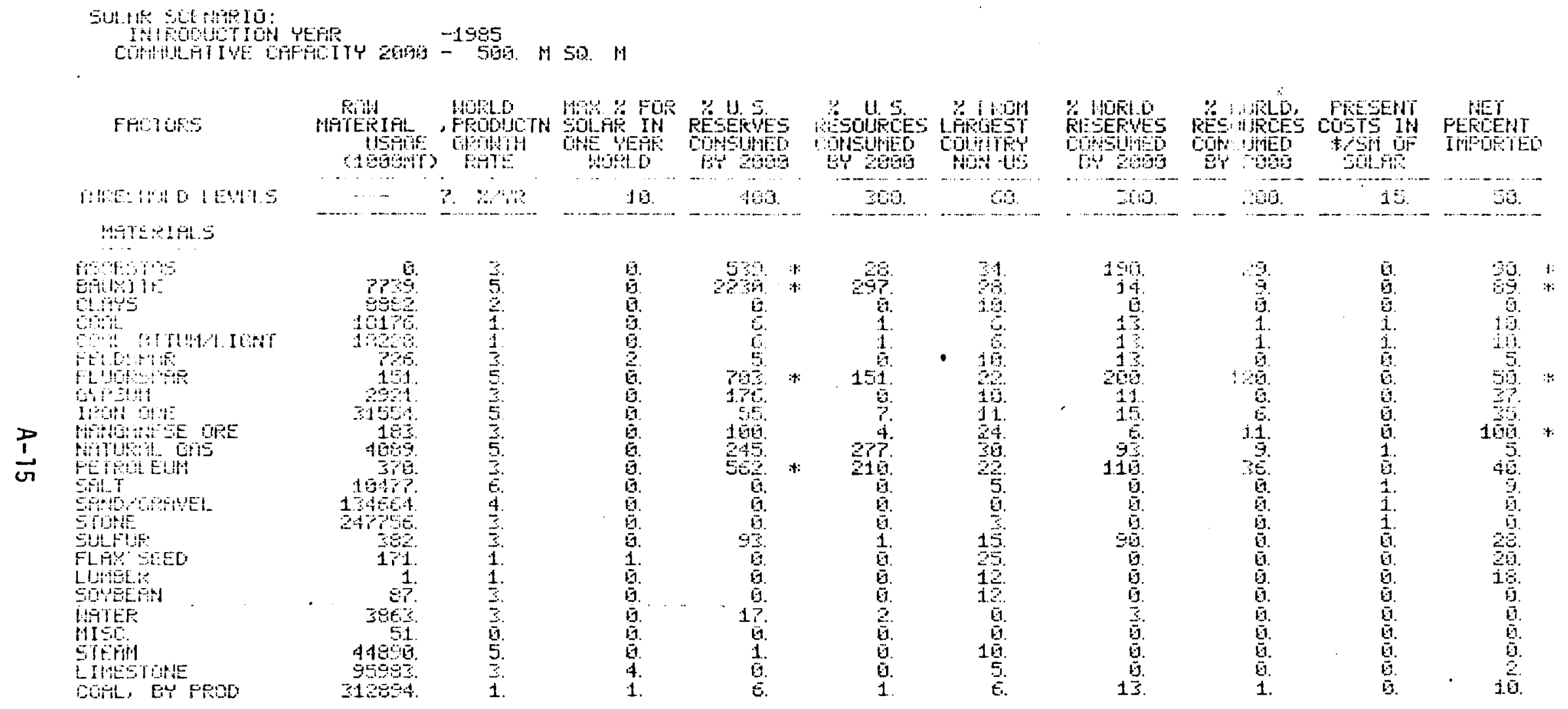


BLIL HITERTAL REQUIFENENT: FUR TRÜHEE WHLL HATER

$\therefore$ ald El.

Indond

\begin{tabular}{|c|c|c|}
\hline FA & $\begin{array}{c}\text { MUETE } \\
\text { URE } \\
\text { AT }\end{array}$ & 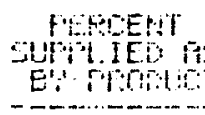 \\
\hline ILO LEYEI: & $\cdots$ & 513. \\
\hline \multicolumn{3}{|l|}{ ferens } \\
\hline Uted & $1.5 \div 9 ? 59$ & 8 \\
\hline CHPiT & 0.4059 & 16. \\
\hline FS: $\quad 0$ COH LIM & 70606 & 57. \\
\hline 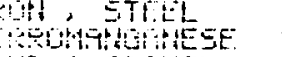 & $\begin{array}{r}150067 \\
1062\end{array}$ & $10 \frac{1}{10}$ \\
\hline HE ! EFPEEL & 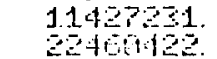 & E. \\
\hline & 70000 & \\
\hline FESIH & & 5 \\
\hline THE & $\begin{array}{l}11915 \\
51025\end{array}$ & 5. \\
\hline$\therefore \mathrm{CH}$ & 8 & $\overline{\mathrm{u}}$. \\
\hline
\end{tabular}

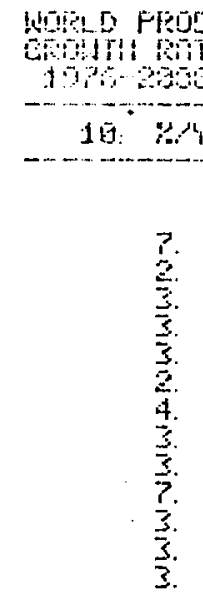
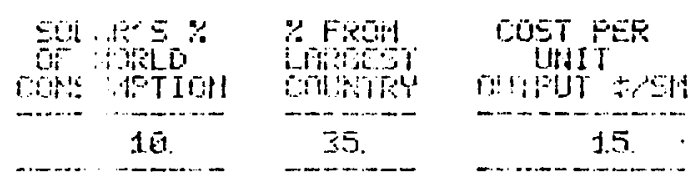

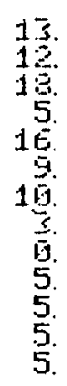

MET

I 5 is.

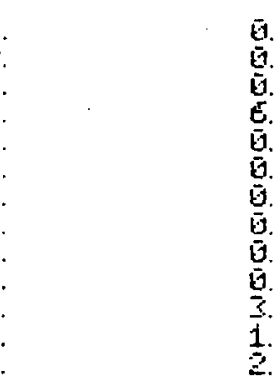

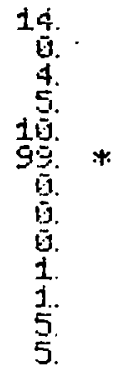




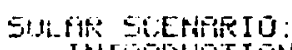

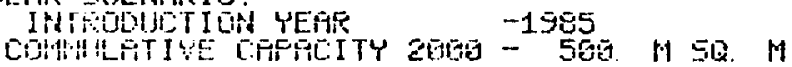

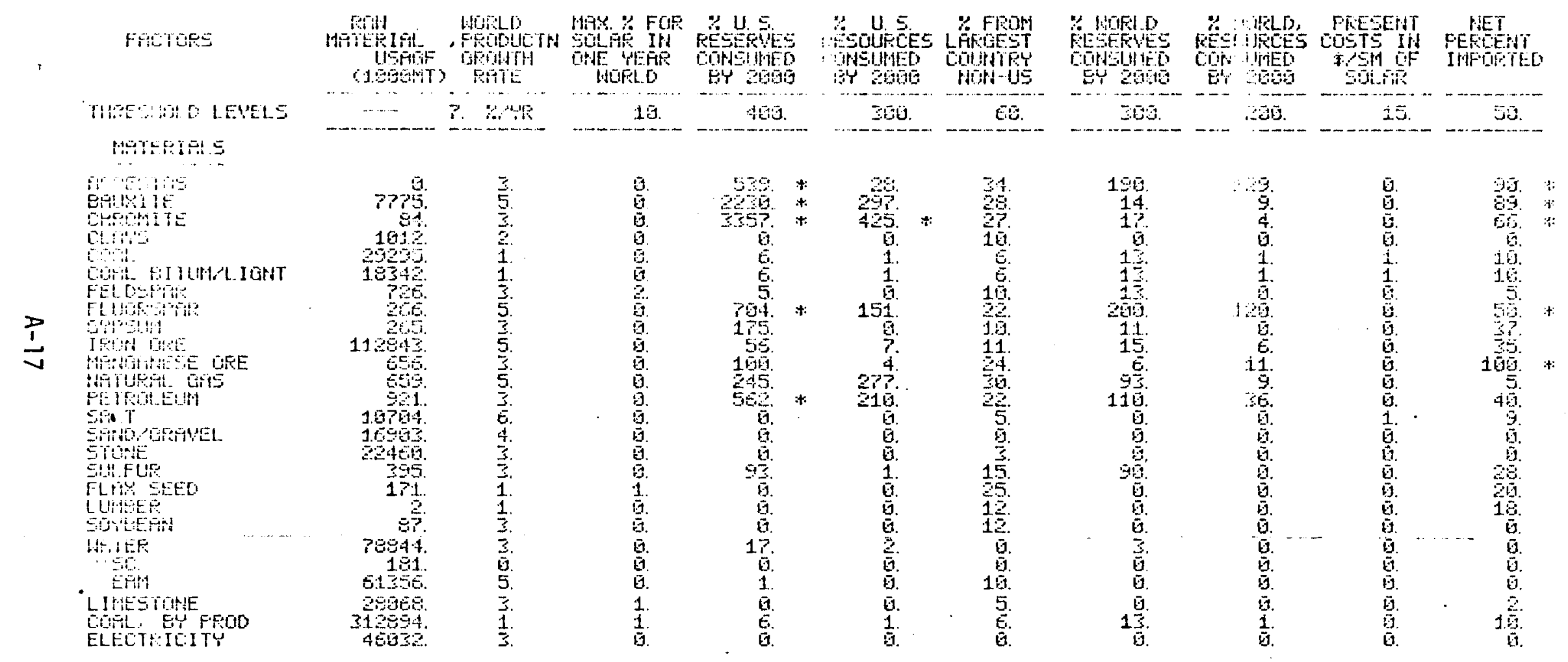




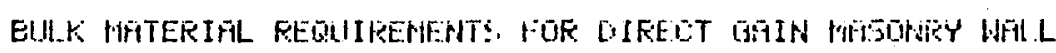

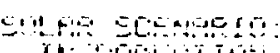

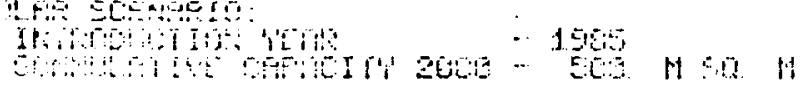

\begin{tabular}{|c|c|c|c|c|c|c|c|c|c|}
\hline $5 \operatorname{lng}$ & 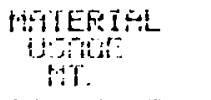 & 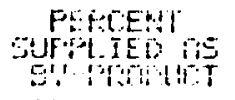 & 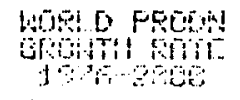 & 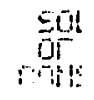 & $\begin{array}{l}\text { OELO } \\
\text { HTod }\end{array}$ & arond & 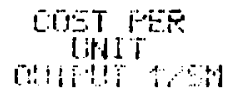 & PEELETT & \\
\hline THEESHAL LEYELS & $; \quad \cdots$ & 50. & 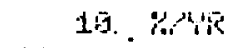 & & $1 \overline{8}$. & 35 & i.5. & 50. & \\
\hline HATECIFLS & & & & & & & & & \\
\hline 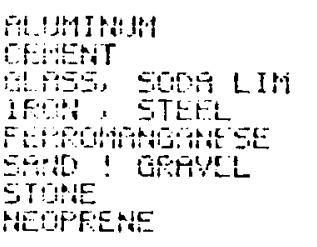 & 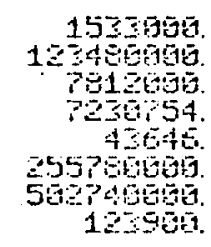 & 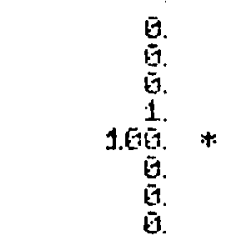 & $\begin{array}{l}\frac{3}{3} \\
\frac{3}{3} \\
\frac{3}{3} \\
\frac{4}{4} \\
\frac{4}{3} \\
\frac{3}{3}\end{array}$ & & $\begin{array}{l}0 . \\
1 . \\
6 . \\
\tilde{g} . \\
0 . \\
1 .\end{array}$ & 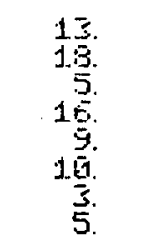 & $\begin{array}{l}3 \\
3 \\
4 \\
5 \\
5 . \\
1 . \\
\frac{1}{3} \\
\frac{6}{4}\end{array}$ & $\begin{array}{r}14 . \\
4 . \\
5 \\
189 \\
99 \\
0 . \\
0 . \\
1\end{array}$ & $*$ \\
\hline
\end{tabular}




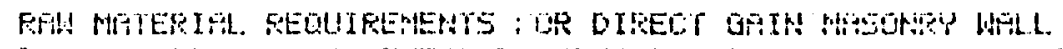

Sthre setrego:

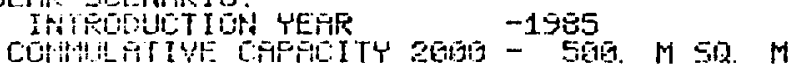

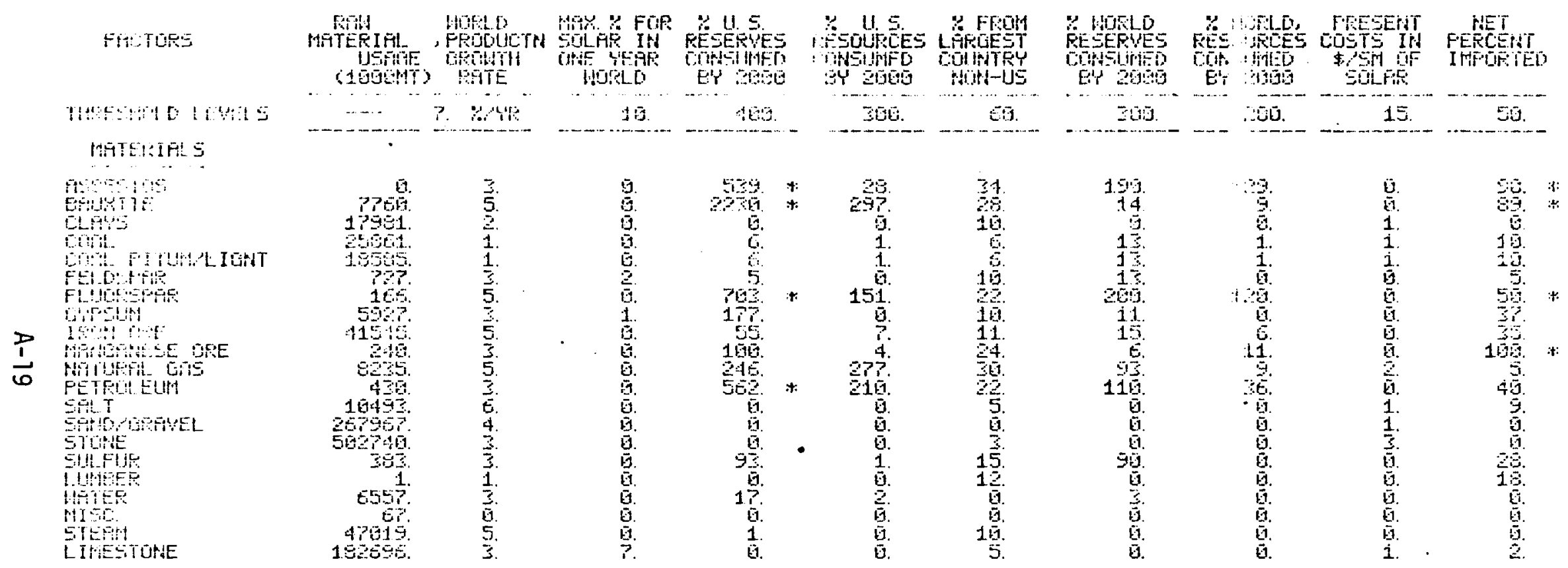


EULK RATERIAI. REQUIREHENTS FOR LIL GÜLAR FÜL

Solp semplo:

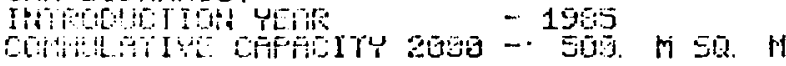

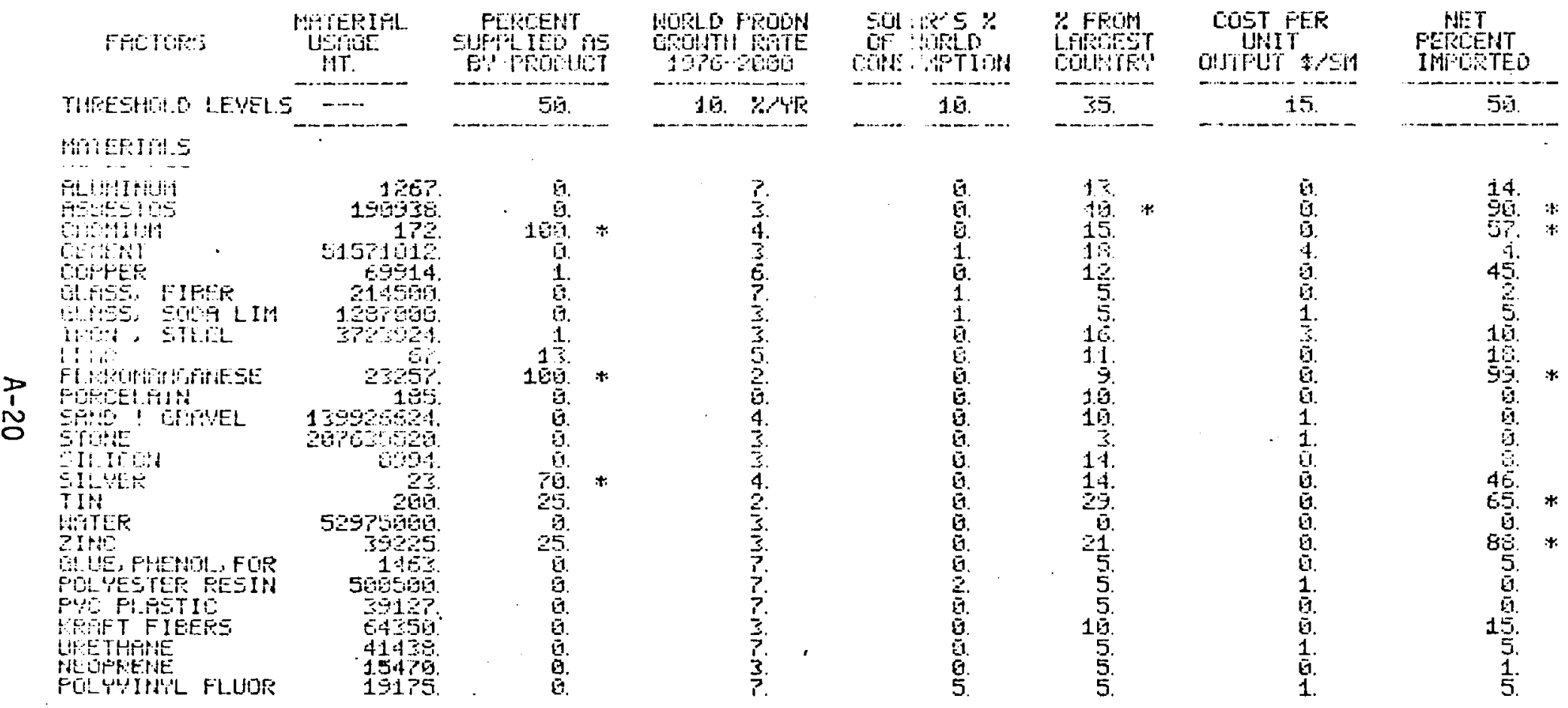




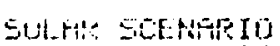

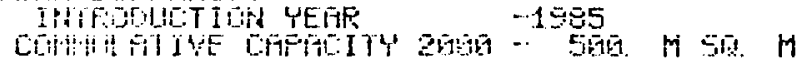

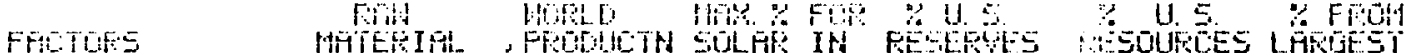

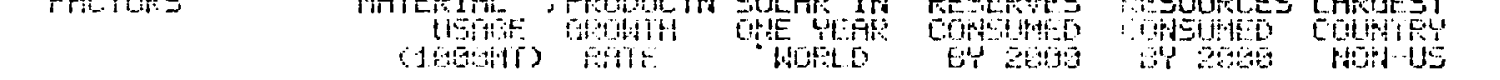

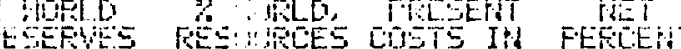

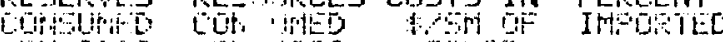
‥

10.40

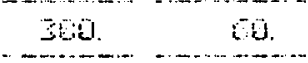

201

20. 35.

\section{Hotorgts}

Fiction

Eitdis

En

Oth tilltill IfH

GOt

$\stackrel{2}{\text { i }}$

5 in

o buts

IfOA GE

HEFin HEE ARE

Pion

A I GU CHO

Fel

ENT T

EHADGEYLL

ILYE OEE

inter

II OEe

IIL EUFROULTS

Luritise

SL UTTEP

WTEE

IIITAT

HIS:

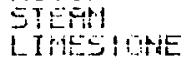

Clin. By pro

CARTEIITY

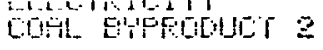

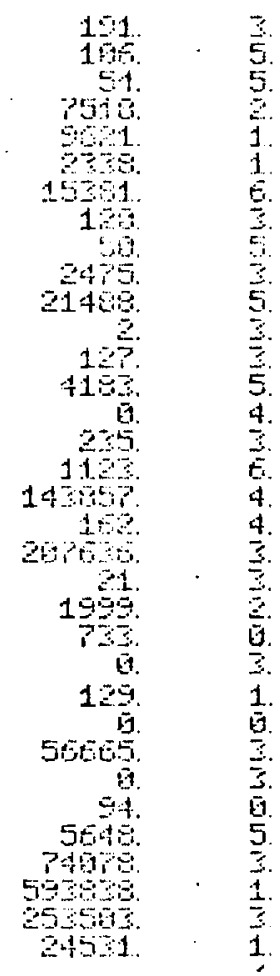

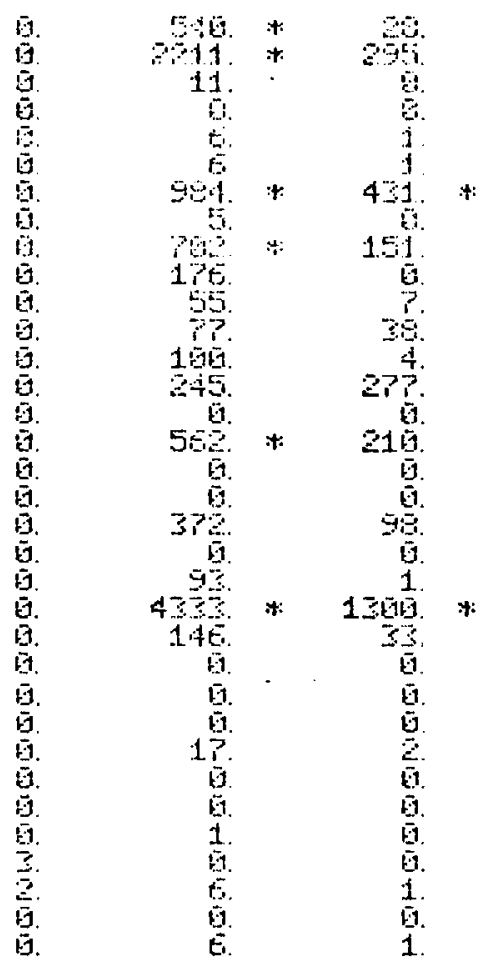

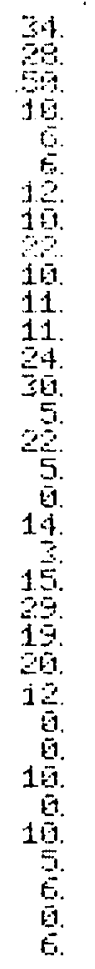

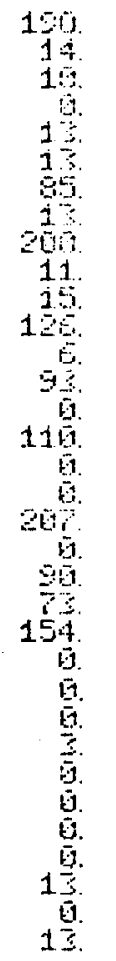

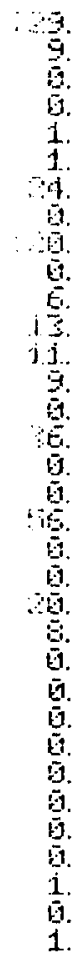

15. 
EUIK MATERIAL REAUIFEHENTS FOR CHAIAEERL FIN - L.UHEER KIL

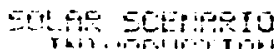

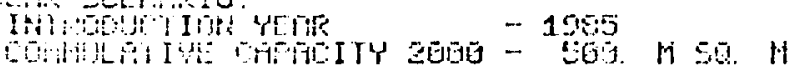

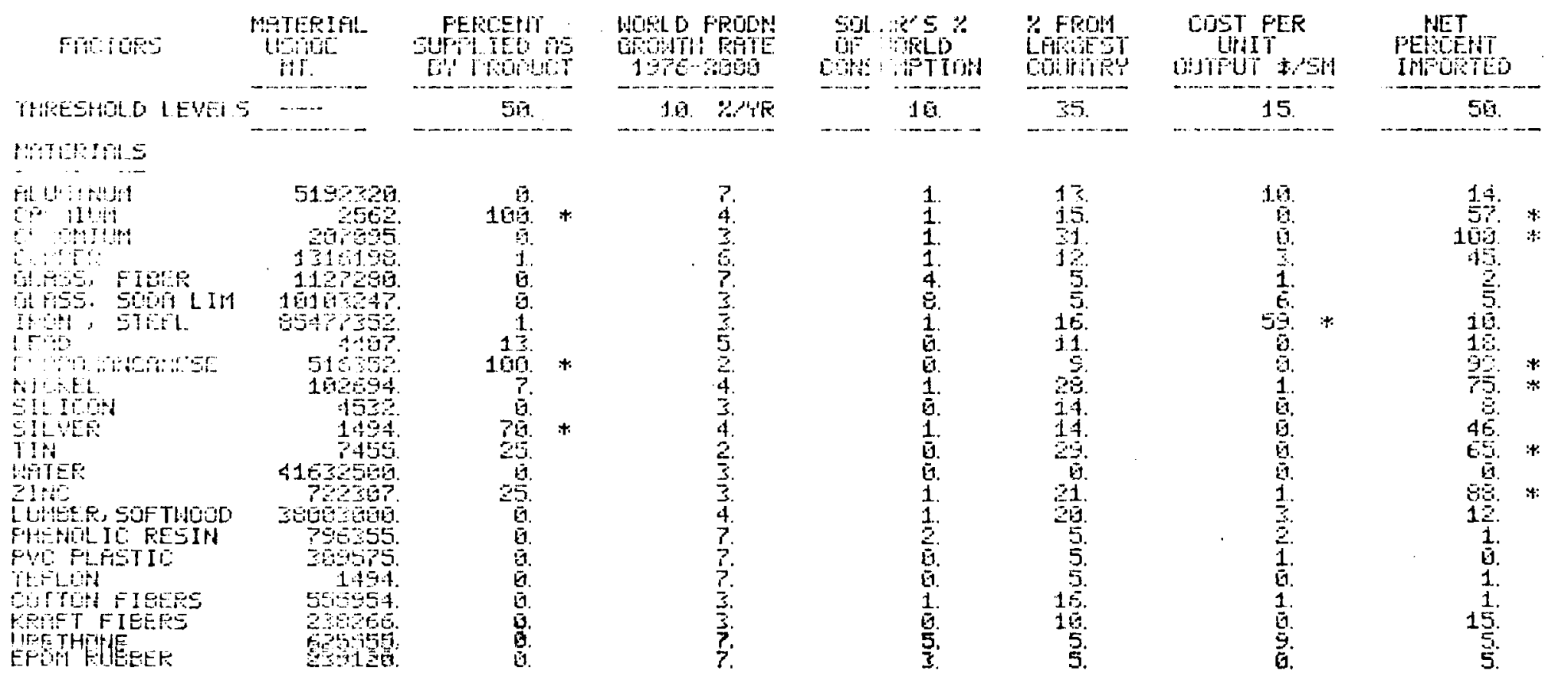




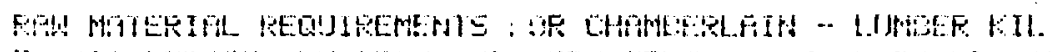

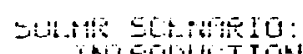

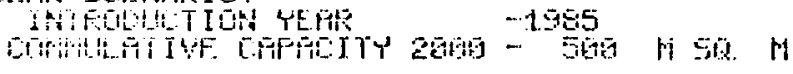

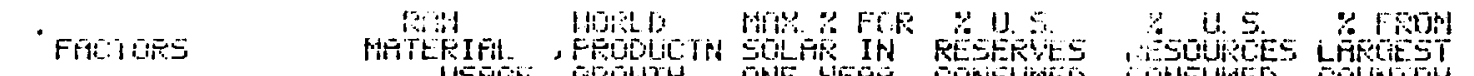

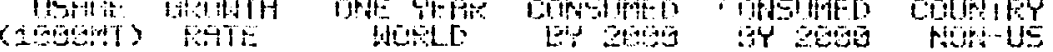

$\because$ HOFO RESERES RES OREE CUSTS IN FEREAT Intotiteo

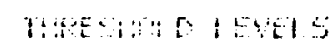
?.

113

20
(ij. . $\therefore$.

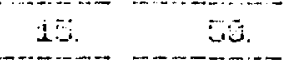
PHTLEIALS

acos

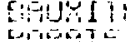

6intia

0 :

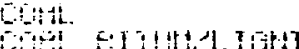

ar 19

P Flum

w IPon or

dintios

tiviluest o

HTYEL TEE

HI TEUTERT, FIYEO

Beigen

PETAOELUA

Sitis

HOSAVL

Etthlipe

TIN GFe

ZINC tot

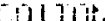

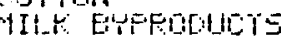

IUHEE

SET MUIER

UTEF

ST

I r.tegringe

EHTL EU PEOD

FLETTEITIS

CHL ENFODUCT 2

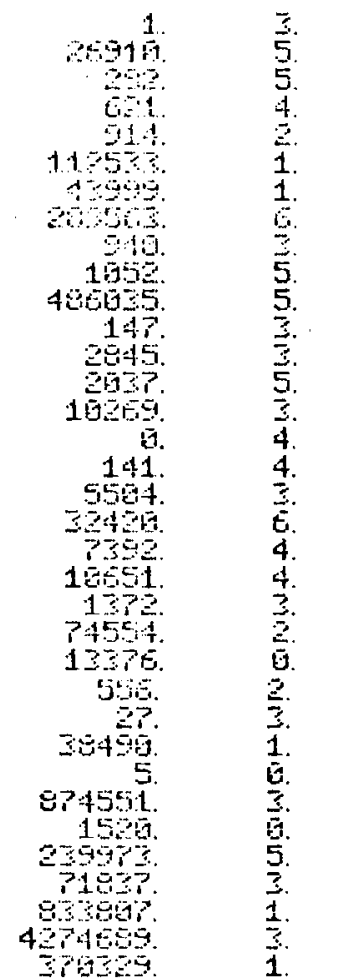

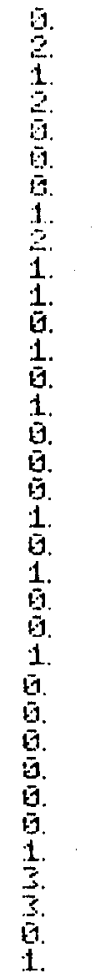

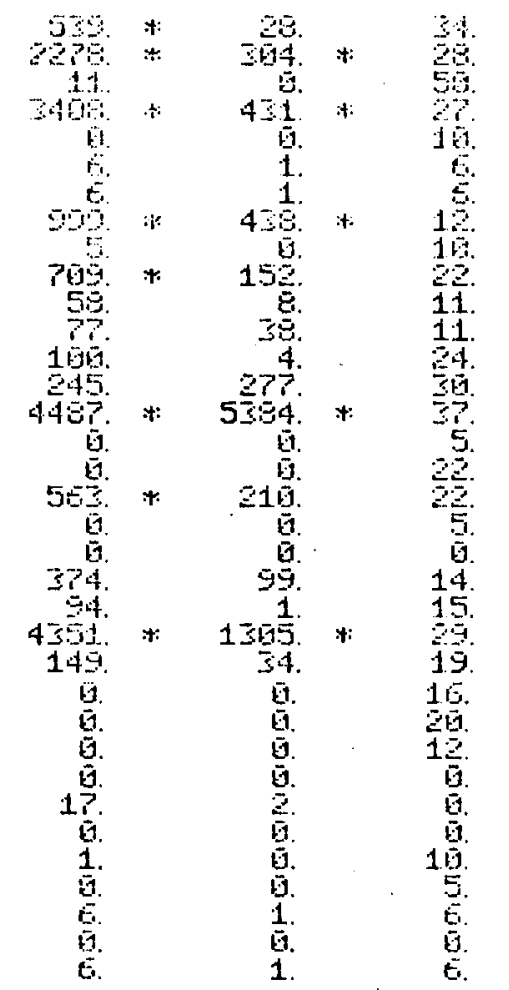

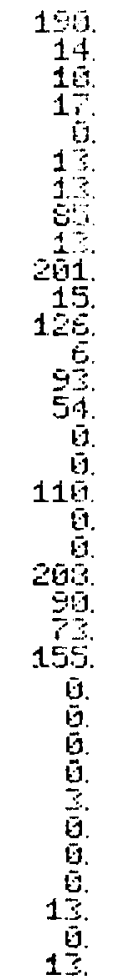

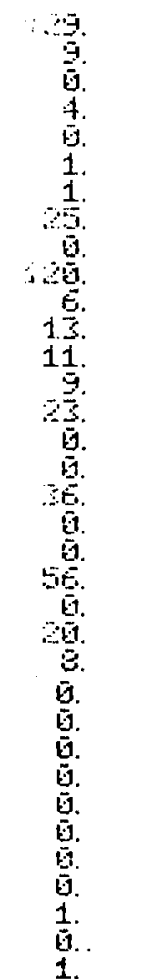

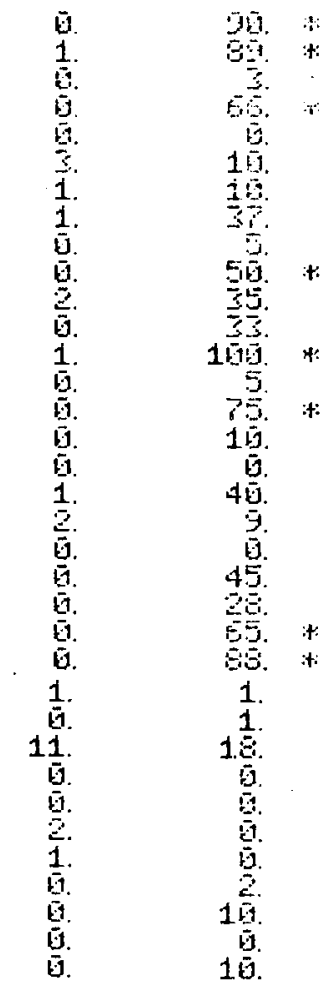




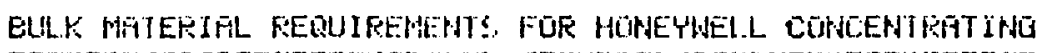

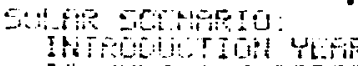

An fin

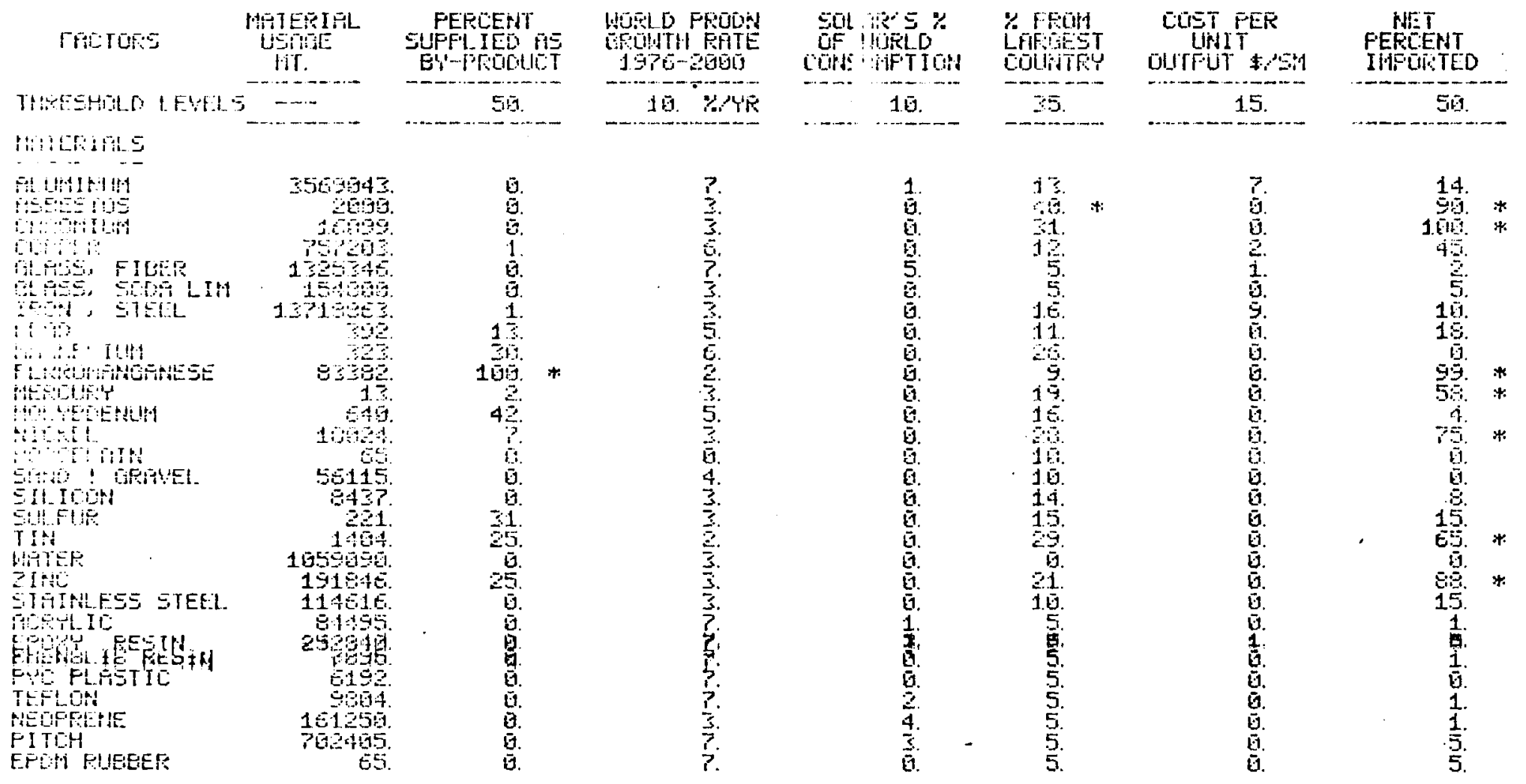




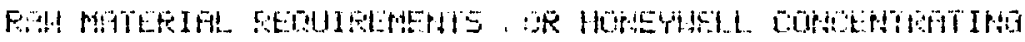

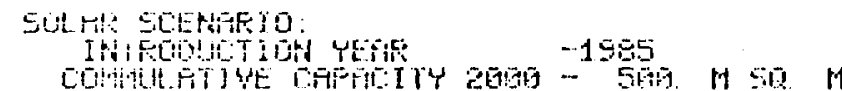

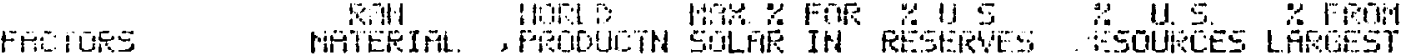

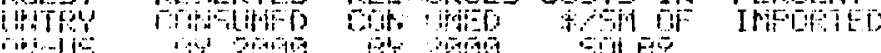

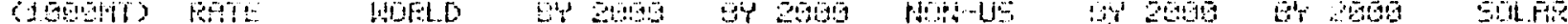

TH: ?. 4

300

a

001. Sis. Norteres

F 619 Eget: CHATIE

avit.

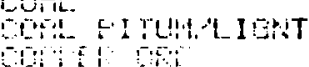
10

No

LEFE

Lint

MErintheE OrE

Mitio

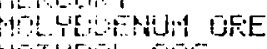

Hitger Ges

MIRE OEE YEO

NI Triage

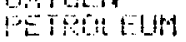

Antom

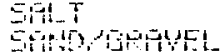

-

Til: $110: 2$

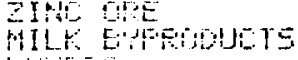

Lom

Hitit:

11:

SIE

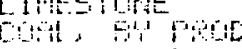

LEOTELI\%

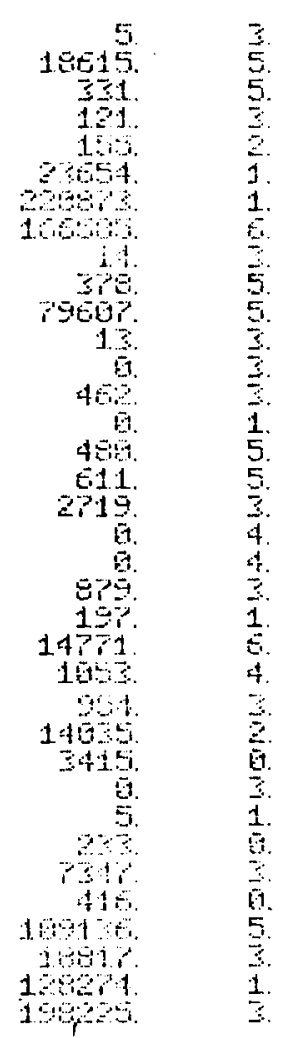

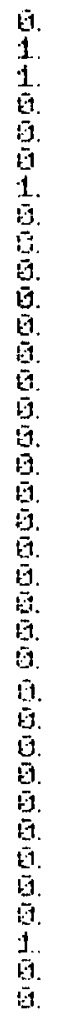

\begin{tabular}{|c|c|c|c|}
\hline 90 & it: & $a$ & \\
\hline की? & $\because$ & 211 & *: \\
\hline 301 & 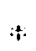 & 48 & $y$ \\
\hline 6 & & 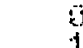 & \\
\hline & & 1 & \\
\hline 10 & t: & 40 & 4 \\
\hline Pot & t: & $15 \%$ & \\
\hline 56 & & i & \\
\hline $7 ?$ & & 30 & \\
\hline 9 & & 4 & \\
\hline 304 & & 573 & $*$ \\
\hline . & & 8 & \\
\hline 4415 & **: & $5=4$ & t: \\
\hline 6 & & 5 & \\
\hline 58 & 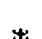 & $=9$ & \\
\hline 13 & $T$ & 3 & \\
\hline 11 & & 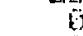 & \\
\hline 15 & & 8 & \\
\hline 24 & & 1 & \\
\hline $4 S 0$ & t: & 1391 & 4 \\
\hline & & 3 & \\
\hline 8 & & 8 & \\
\hline 19. & & 8 & \\
\hline 17 & & 8 & \\
\hline 11. & & 8 & \\
\hline 1 & & 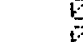 & \\
\hline & & 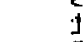 & \\
\hline 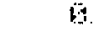 & & 1 & \\
\hline
\end{tabular}

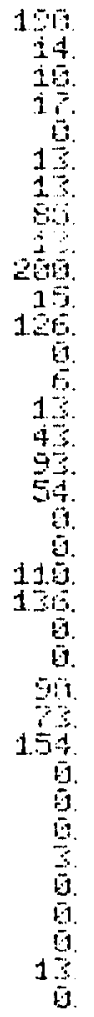

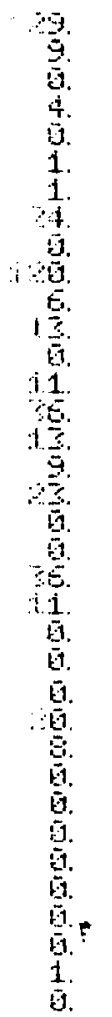

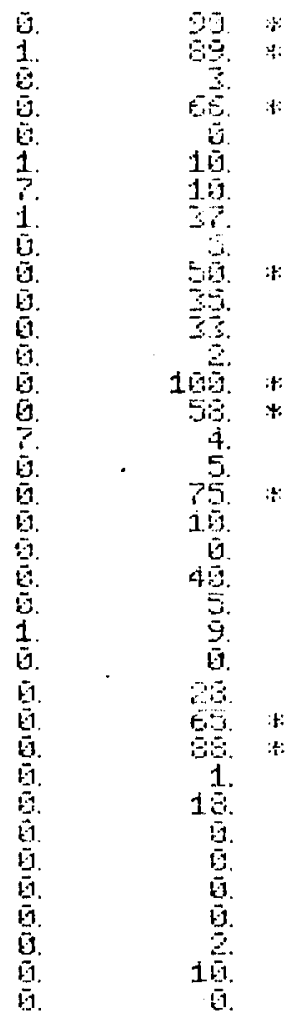


BULK MATERIAL SUMMARY REPORT

SHACOB Mixed System Scenario: Introduction Year - 1985

Cummulative Capacity by the Year 2000 - 500 M. Sq. 11.

Composed of 9 SHACOB Designs Each at 55.6 M. Sq. M.

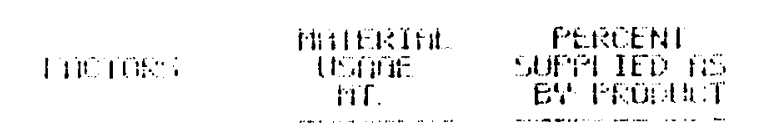

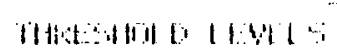
tin

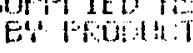

51.

Hithins

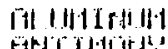

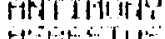

rative

ailitiliti

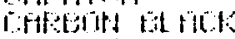

ETHERT

EHertint

T11 था Tि:

ij ilis. 1 1 itit?

Bl

ni, Misind

勇

Inting

ait 11

iflint

Mrivites SLINT

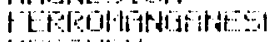

Ptt tet le?

NICtE: DATLL

sifilo

ints:

SIIUte?

II yt

Hitet

inifr

TIIIHALS STEA

जिlिए eEs

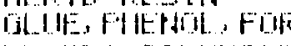

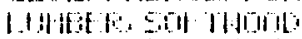

Pritall it ets it

Pht Flfist

IIIIU⿴囗十⺝

TEFind

phis aty

COITOH F IEE $=$

Eसt T IBEs

lut 11 hith

Het int in

PHFifR AlE

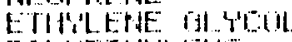

PUI IE THY'L FH

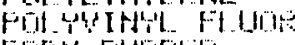

EFCH FISELE

Prith THI thdt?

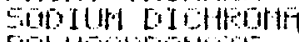

Pat ichitoritste

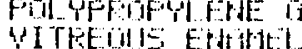

indins:

\begin{tabular}{|c|c|c|c|c|}
\hline 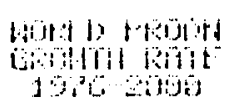 & 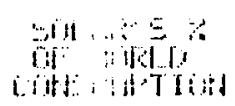 & 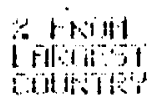 & 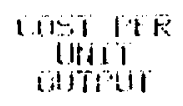 & 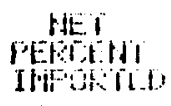 \\
\hline J日 & $1 \bar{U}$ & 35 & 1.9 & Eno. \\
\hline
\end{tabular}

510.

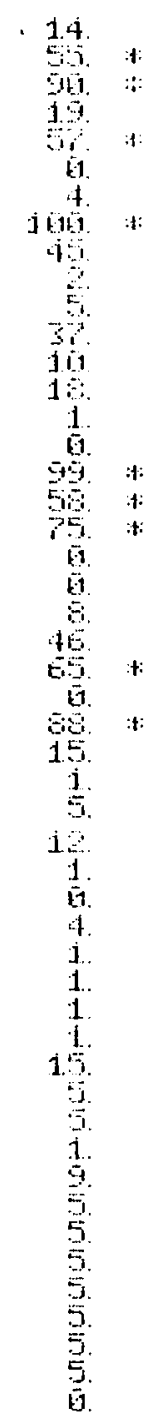


SHACOB Mixed System Scenario: Introduction Year - 1985

Cummulative Capacity by the Year $2000-500$ II. Sq. M.

Composed of 9 SHACOB Designs Each at 55.6 M. Sq. M.

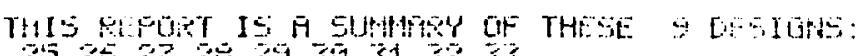

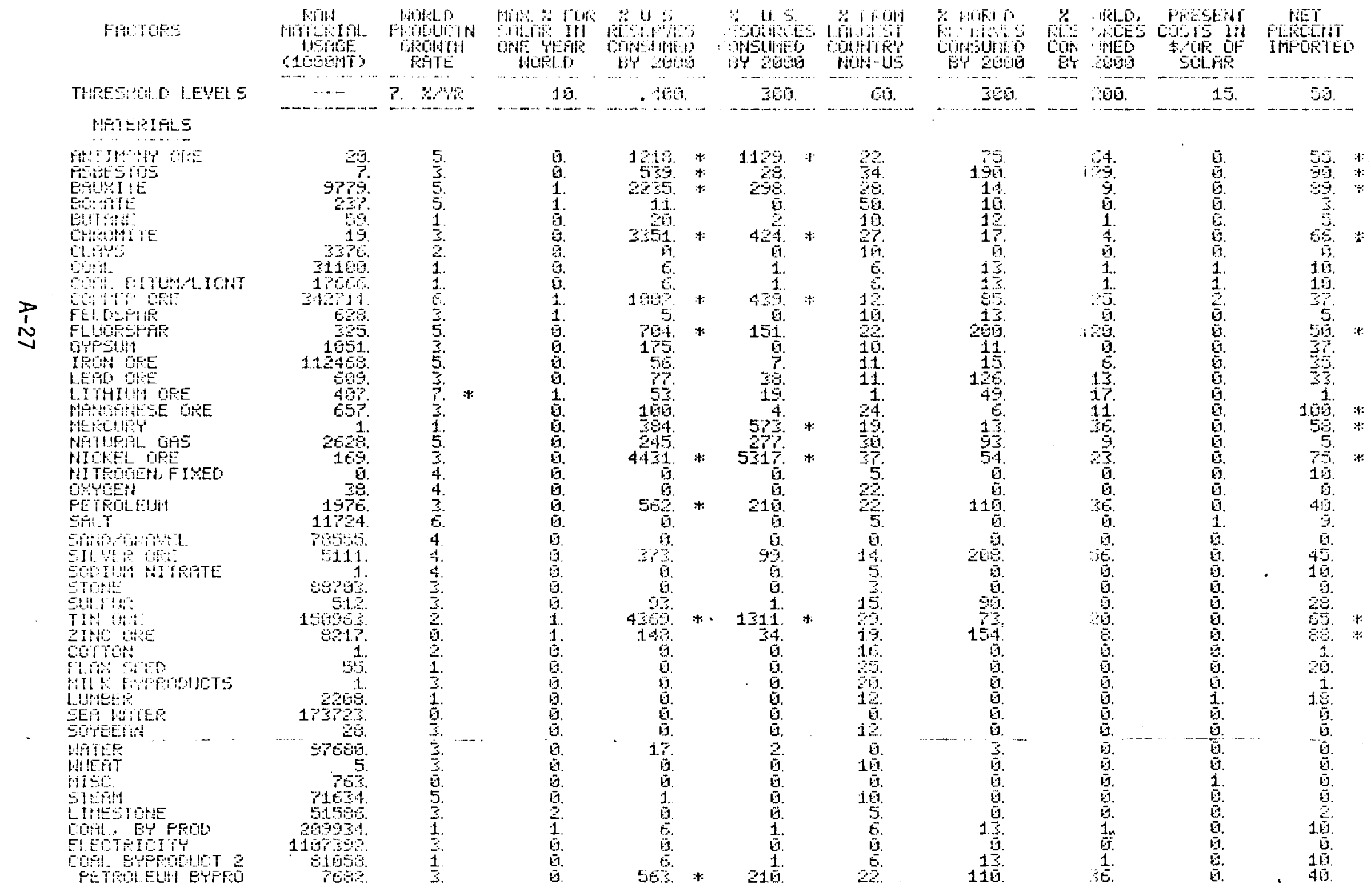


SHACOB Mixed System Scenario: Introduction Year - 1985 Cummulative Capacity by the Year 2000 - 1000 M. Sq. II.

Composed of 9 SHACOB Designs Each at $111.1 \mathrm{H}$. Sq. 11 .

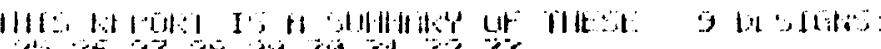

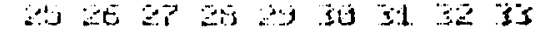

\begin{tabular}{|c|c|c|c|}
\hline 17110 & 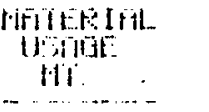 & \multicolumn{2}{|c|}{ 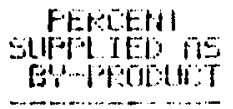 } \\
\hline IIISSUI C IFU1 & ........ & \multicolumn{2}{|l|}{$51 \%$} \\
\hline 1HAt:lith & & & \\
\hline 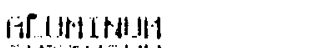 & 5080000 & G. & \\
\hline$m_{1}$ & 369 & 1हाँ & 4 \\
\hline ntt:olds & 12493 & 5 & \\
\hline tifolth: & $21 E \overline{9} ?$ & 5 & \\
\hline CifHIIH & 1002 & 1001 & y: \\
\hline OfHent ELrAts & 92591. & $16 \mathrm{E}$. & $\pi$ \\
\hline chtithat & 135324561 & $\overline{1}$ & \\
\hline entendiun & 1585 & 它. & \\
\hline Bता & 160656 & i & \\
\hline af ine lIface & 100005 & $\overline{11}$. & \\
\hline 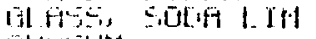 & $1209=3 ?$ & 19 & \\
\hline Gitallat & 450 & 1. & \\
\hline linits shits. & 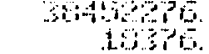 & 1 & \\
\hline I I IIIII:H & $18 i E$. & $a$ & \\
\hline 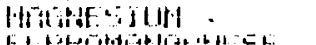 & 1409 & 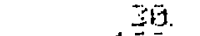 & \\
\hline 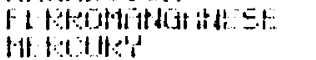 & $2-205$ & $1 . \bar{g}$ & t: \\
\hline मीनास & 1555 & $\%$ & \\
\hline 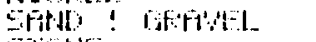 & $1+4+691=$ & 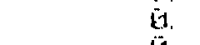 & \\
\hline STHEE & 1706094. & 6 & \\
\hline Ell rint & 508 & 5 & \\
\hline silnetere & 143 & 30 & $\pi$ \\
\hline Withes & $p+19=90$ & $=8$ & \\
\hline 211 & $5199 ? 6$. & 25 & \\
\hline$B S E S 1 E F L$ & 1 & 6. & \\
\hline RESIH & $19+14$ & $\overline{1}$. & \\
\hline GIUE, FHIEHU, Flie & 3208 & เె. & \\
\hline L. Indere and ldine & $120100 \%$ & 5. & \\
\hline 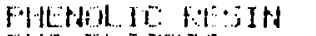 & $5+5$ & $\ddot{1}$ & \\
\hline 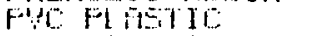 & $499 \%$ & (1). & \\
\hline 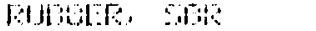 & $1038 \%$ & $\overline{19}$. & \\
\hline $4=5$ & 1200 & 17 & \\
\hline 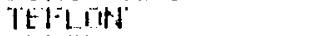 & 3645 & 5. & \\
\hline & 207 & (1) & \\
\hline Cortund FIBEs & 1453 & 17. & \\
\hline PIEl & & 6 & \\
\hline UIA Hllite & $2+383$ & $\bar{b}$ & \\
\hline Figlitili & 30065 & 1 & \\
\hline NIE & 235 & $=$ & \\
\hline ETHALERE GLSEOH & 49395 & घิ. & \\
\hline FUL YETHAL EHE & 984 & (1) & \\
\hline 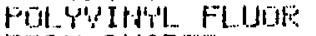 & DEEtE & 5 & \\
\hline EF[N FULEER & 5942 & ติ & \\
\hline FAINT THITULEF & 375 & $\underline{\underline{1}}$. & \\
\hline 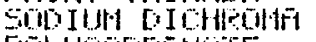 & 10 & $\underline{\text { s. }}$ & \\
\hline FOL SOAEETHAI & 16 & & \\
\hline PFPCLFU & 28600 & $\overline{10}$ & \\
\hline 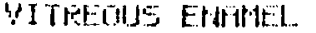 & 70543 & $\overline{\mathbf{\theta}}$. & \\
\hline
\end{tabular}

\begin{tabular}{|c|c|c|c|c|}
\hline 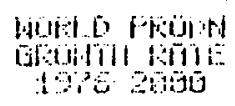 & 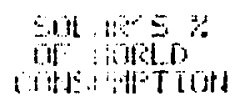 & 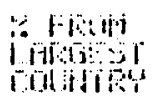 & 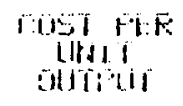 & 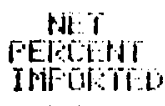 \\
\hline 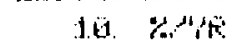 & 11 & 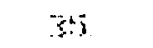 & 15 & 50 \\
\hline
\end{tabular}
$5 \overline{10}$ 


\section{RAW MATERIAL SUMMARY REPORT}

SHACOB Mixed System Scenario: Introduction Year - 1985

Cummulative Capacity by the Year 2000 - 1000 M. Sq. M.

Composed of 9 SHACOB Designs Each at 111.1 M. Sq. M.

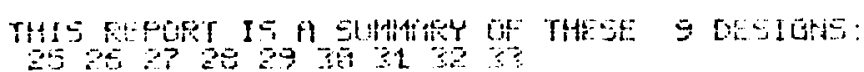

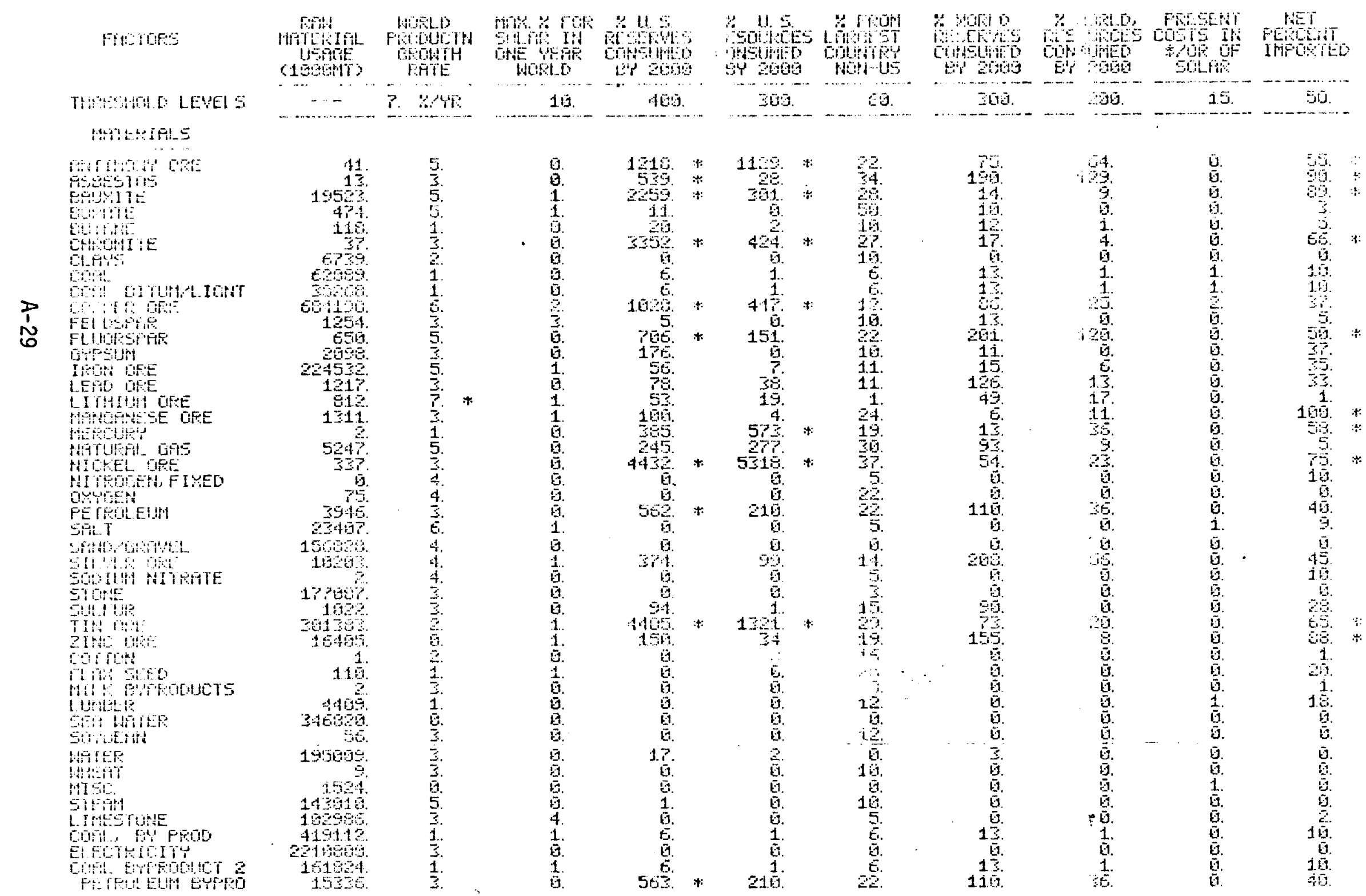


AIPH Mixed System Scenario: Introduction Year - 1985

Cummulative Capacity by the Year 2000 - 500 M. Sa. M.

Composed of $3 \mathrm{AIPH}$ Designs Each at 166.7 M. Sq. M.

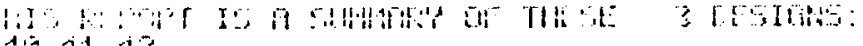

4641.2

\begin{tabular}{|c|c|c|}
\hline ris:os & 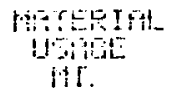 & 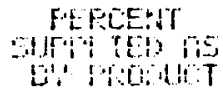 \\
\hline EA:40 IFYA & & 50 \\
\hline
\end{tabular}

\begin{tabular}{|c|c|c|c|c|c|}
\hline 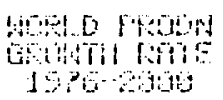 & $\begin{array}{l}a \\
6\end{array}$ & 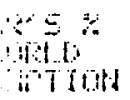 & 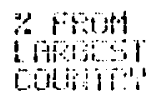 & 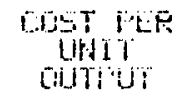 & $\begin{array}{c}\text { RET } \\
\text { PEAERT } \\
\text { I Hi UTEL }\end{array}$ \\
\hline 19. & & 15 & 25 & 15. & 56 \\
\hline
\end{tabular}

Hisirelati:

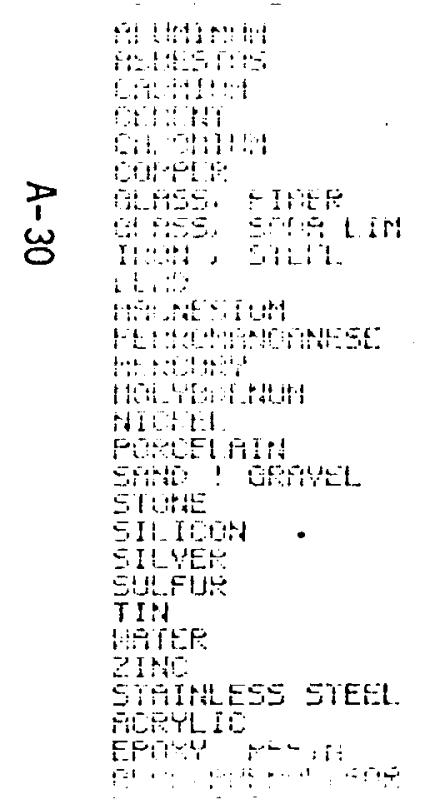

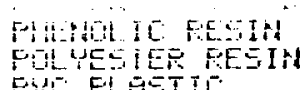
FU: FLFETE

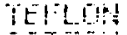
QTin PIOES ATT FIETE

Hothe

HOHCHE

PTrts

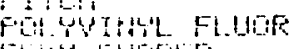
Erits

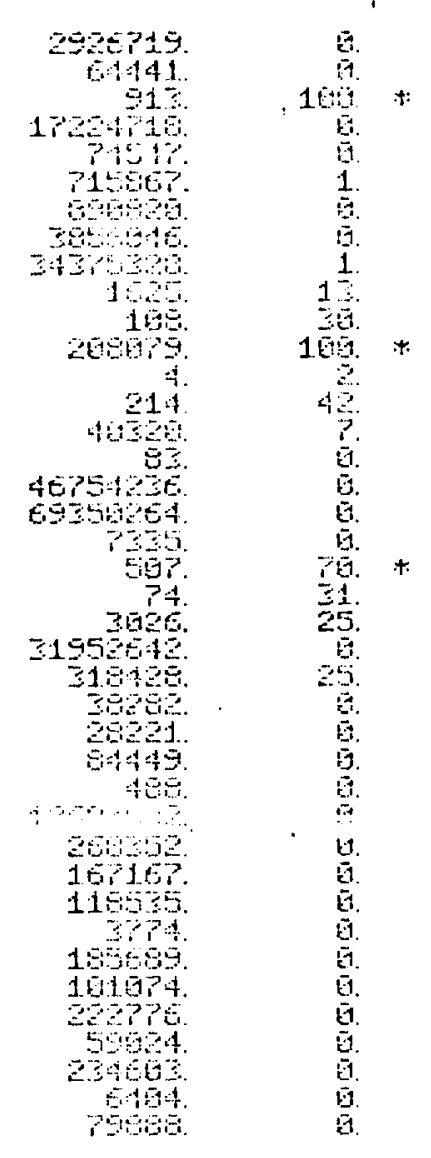

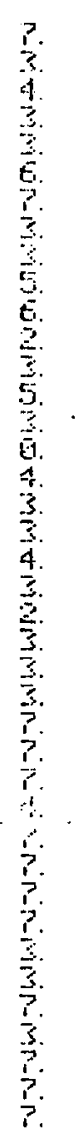

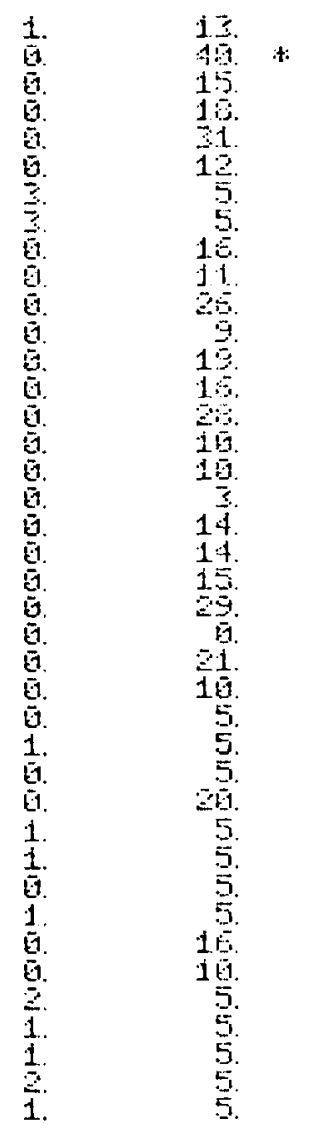
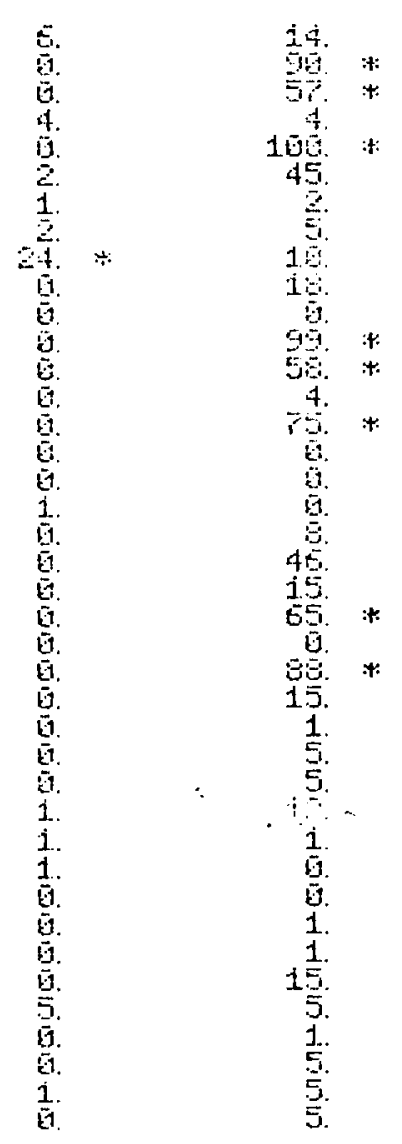


\section{RAW MATERIAL SUMMARY REPORT}

AIPH Mixed System Scenario: Introduction Year - 1985

Cummulative Capacity by the Year 2000 - 500 11. Sq. II. Composed of 3 AIPH Designs Each at 166.7 11: Sq. 11.

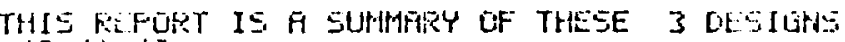
$4041 \%$

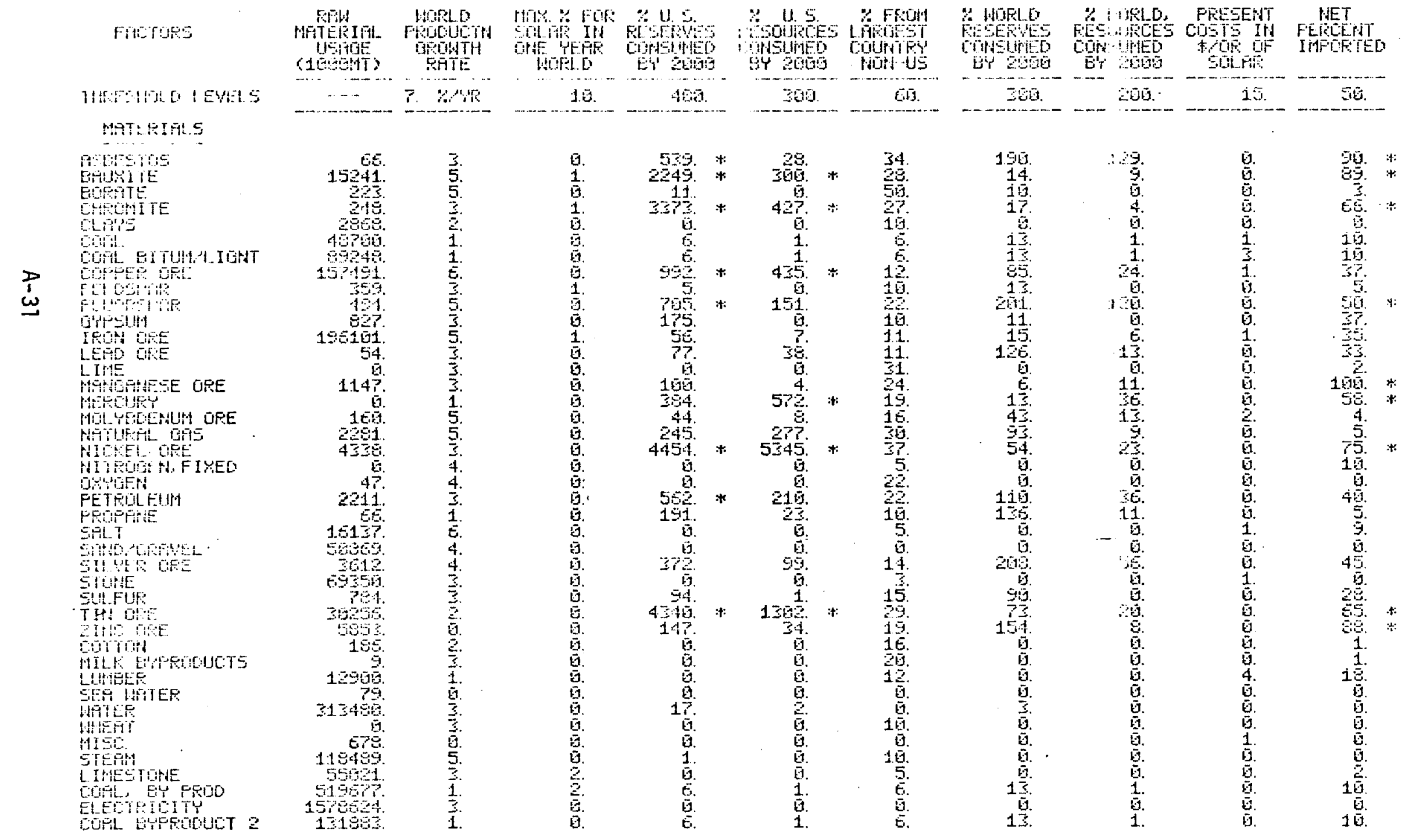




\section{BULK MATERIAL SUMMARY REPORT}

AIPH Mixed System Scenario: Introduction Year - 1985

Cummulative Capacity by the Year 2000 - 1000 M. Sq. M.

Composed of 3 AIPH Designs Each at 333.3 11. Sq. M.

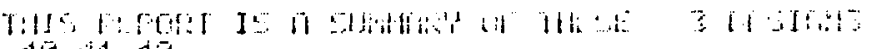

45 41 $4:$

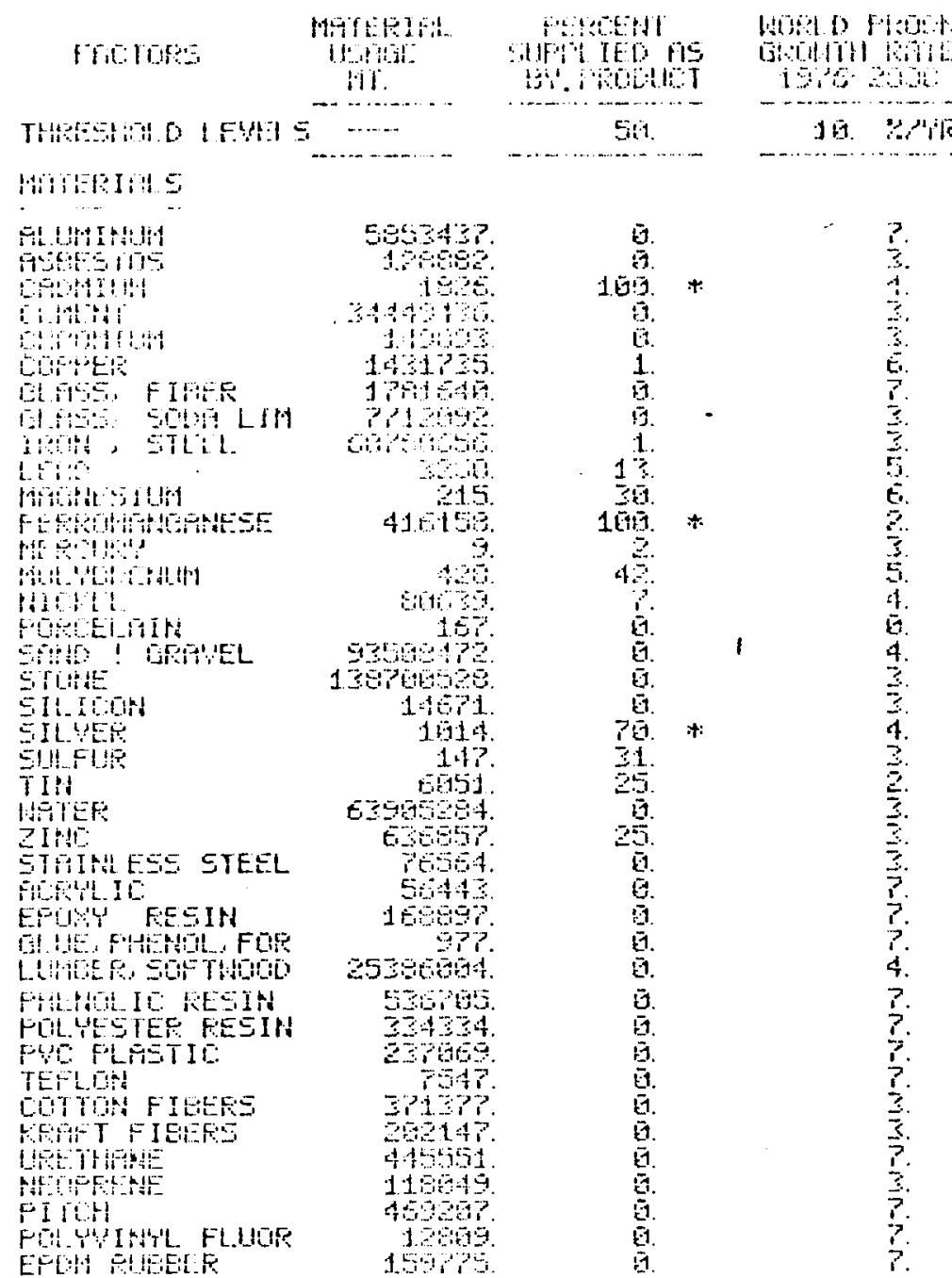
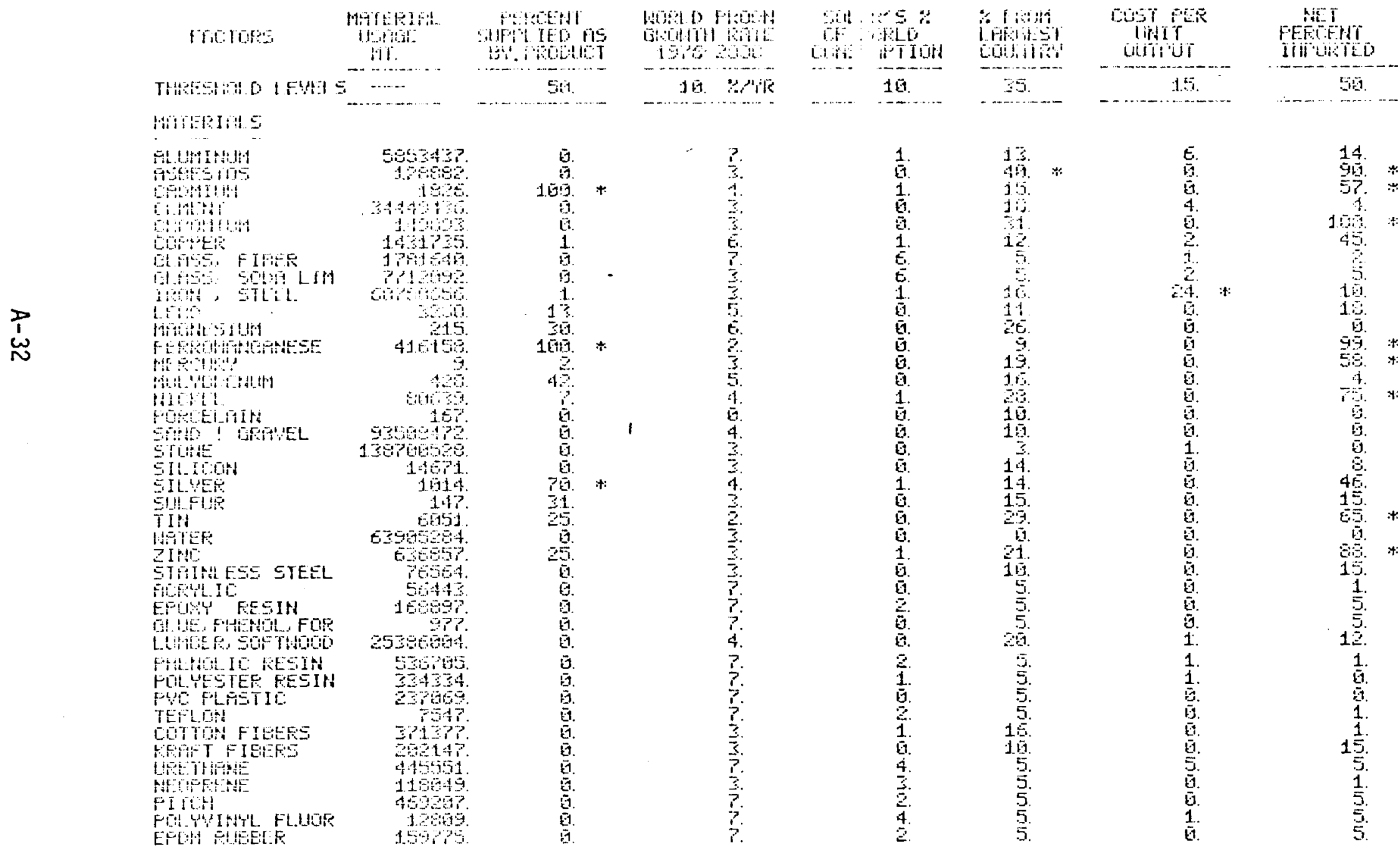

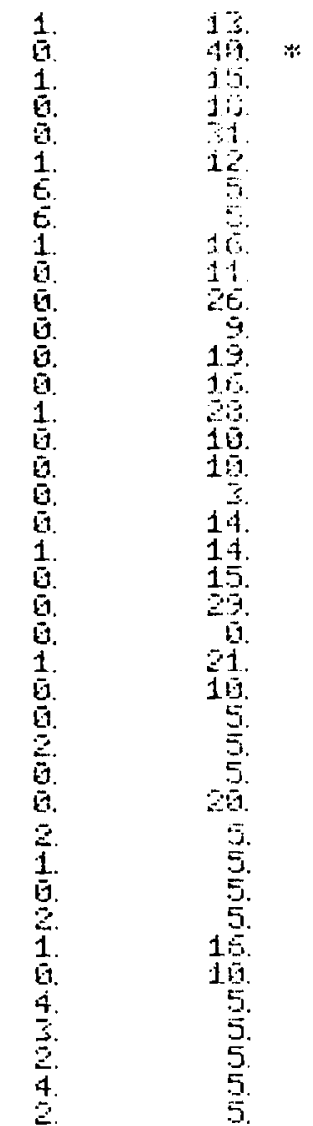

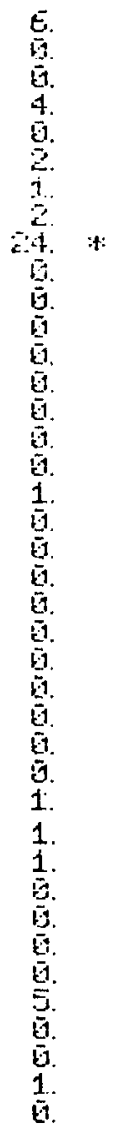

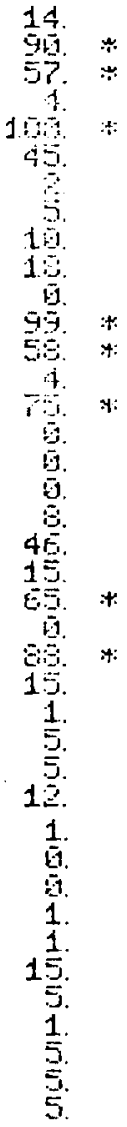


RAW MATERIAL SUMMARY REPORT

AIPH Mixed System Scenario: Introduction Year - 1985

Cummulative Capacity by the Year 2000 - 1000 M. Sq. M.

Composed of 3 AIPH Designs Each at 333.3 M. Sq. M.

THIS REFGRT IS A SUMMTARYY OF THESE 3 CESIGMS:

404142

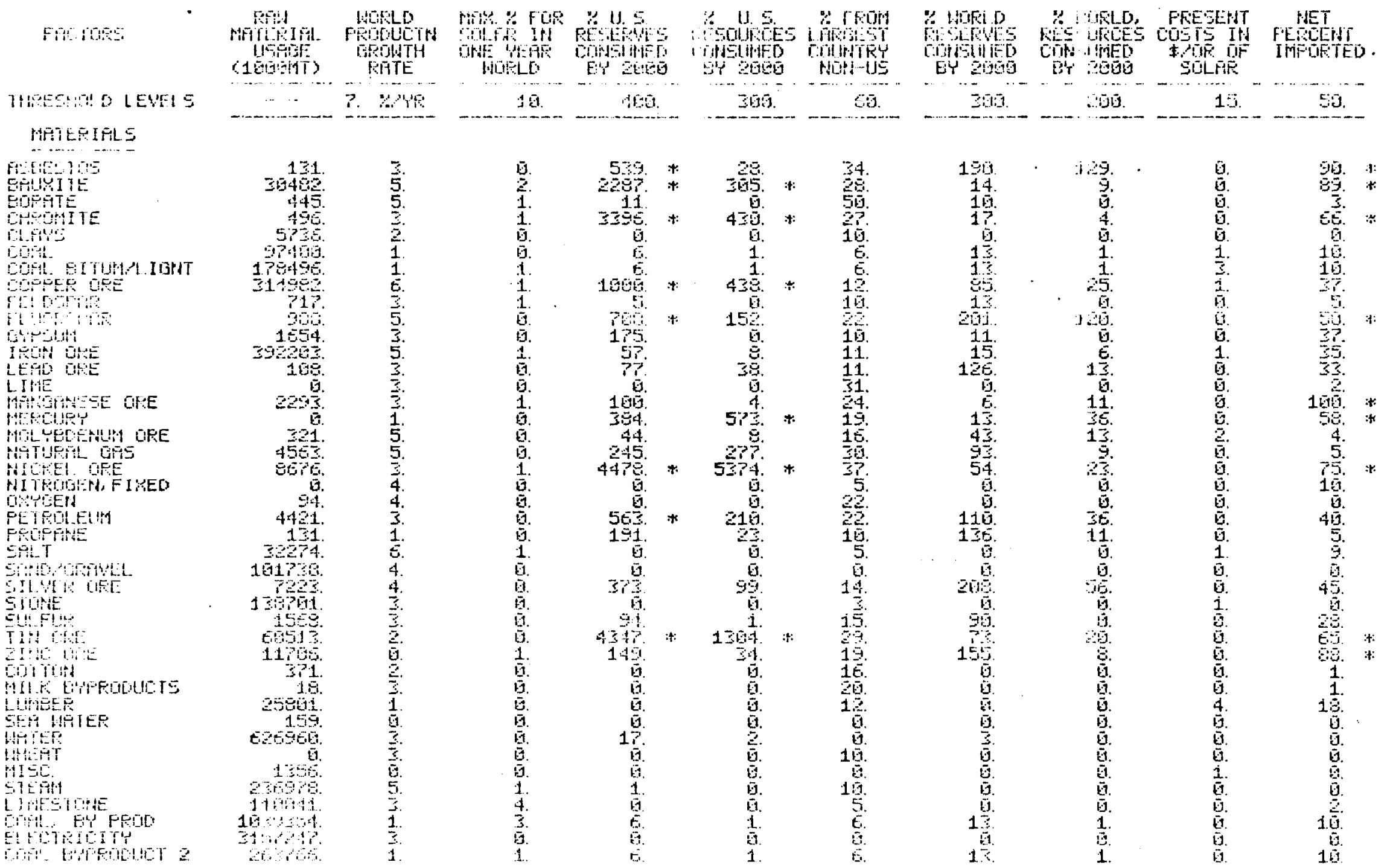


- 


\section{APPENDIX B}

SOLAR SYSTEMS DESIGN CHARACTERIZATION AND MATERIAL REQUIREMENTS ${ }^{\star}$

by

T. B. Correy

W. E. Gurwe11

E. I. Husa

J. 0. Vining

Page

SHACOB snd AIPH System Identifications

Design Characterizations and Material Requirements

Design

Number

Short Title

SHACOB

25

SUNWORKS RES HW

$B-2$

26

SOLARON-RES HT

B-6

27

SOLARON-RES HT + HW

B-10

28

AMER HELIOTHERMAL $\mathrm{H}+\mathrm{HW}$

B-14

29

KTA AND ECOSOL HEAT PUMP SY

B- 18

30

RAYPAK - HT + COOL + HW

B-21

31

TROMBE WALL CONCRETE

B-25

32

TROMBE WALL WATER

B-28

33

DIRECT GAIN MASONRY WALL

B-31

$\underline{\mathrm{AIPH}}$

40

LLL SOLAR POND

B-34

41

CHAMBERLAIN - LUMBER KILN

B-38

42

HONEYWELL CONCENTRATING

B-42

Energy Contribution Calculations

B-46

*Material Requirements are in kilograms 


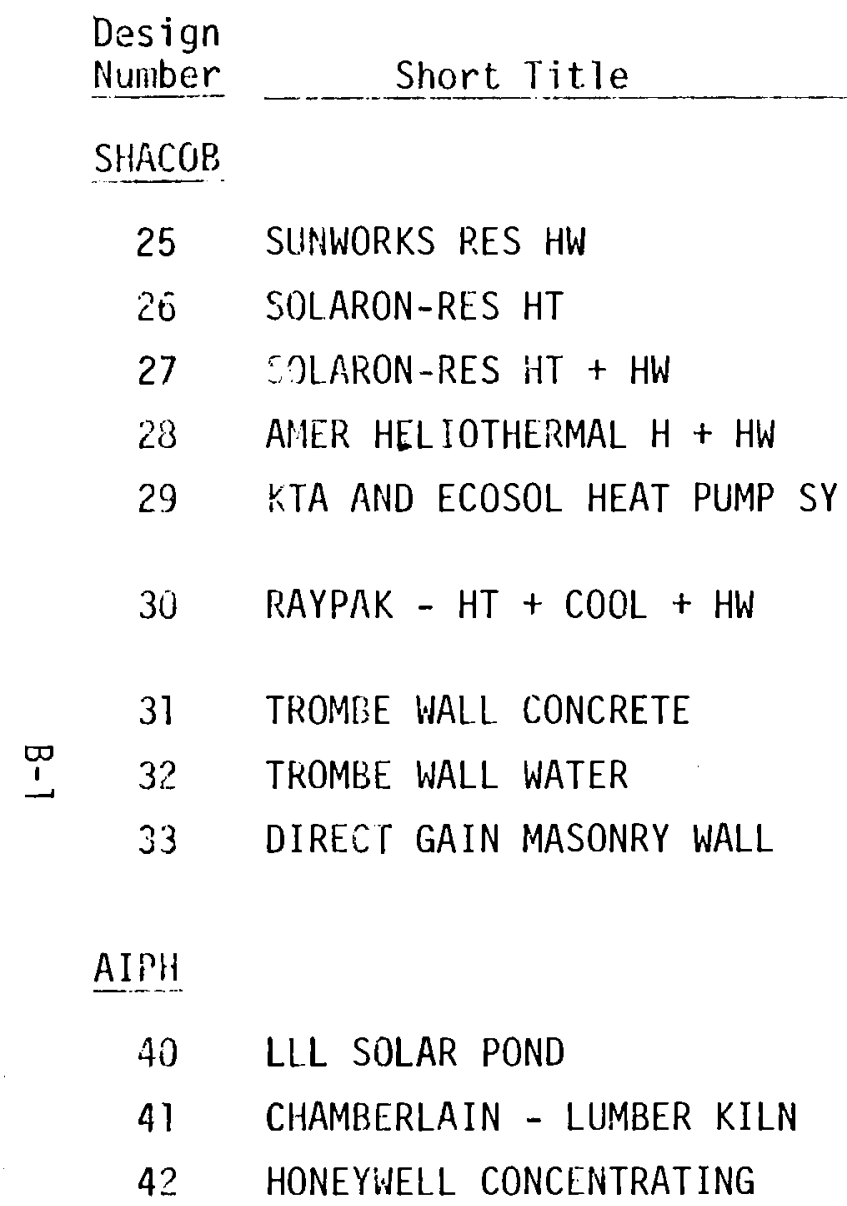




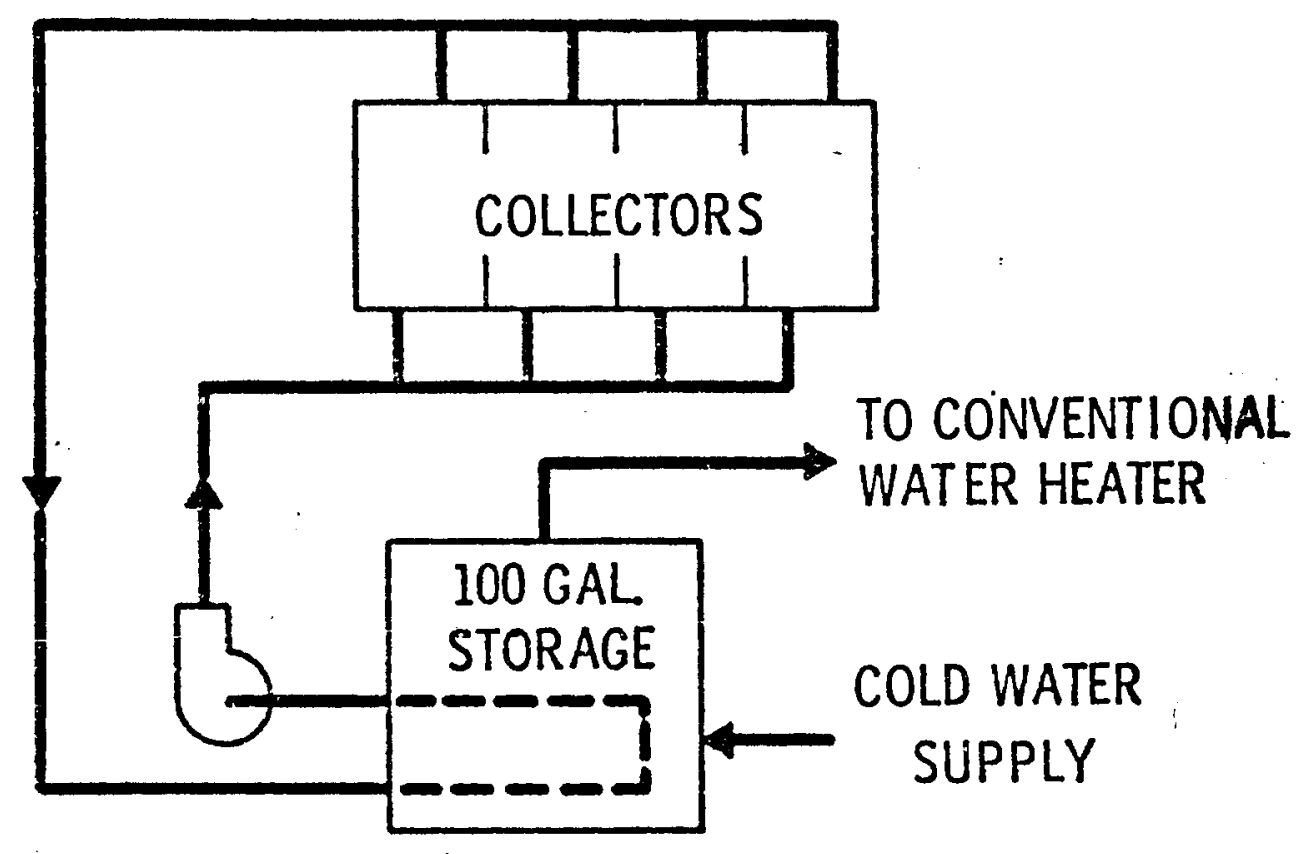

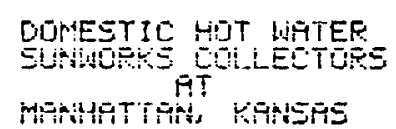

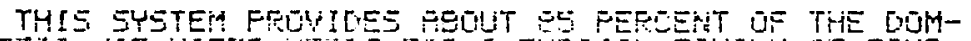

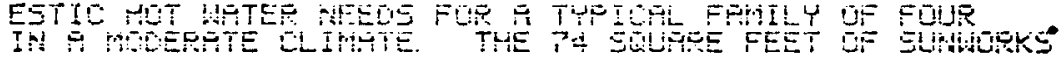

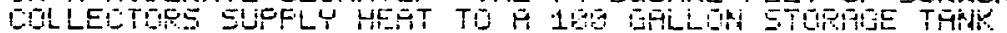

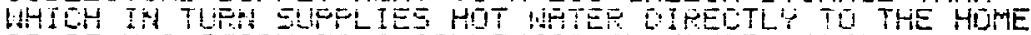

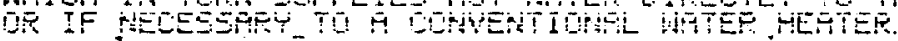

TELHHILLOTY

CAPREITY

FitPLicition

GTSOH

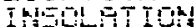

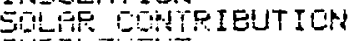

SIFPLENEHT

STLE EFFICIERTY

CLLCOCP HEC

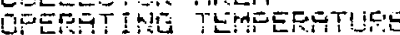

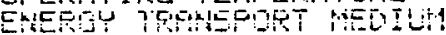

STOESTE TUE

STCEAE COAIT
SHFOU日

25 MJ HULR

QUSETC HOT HATE

A

E J UTOUURE FEST-4ERR

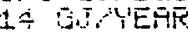

TES LELE

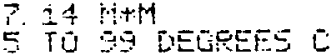

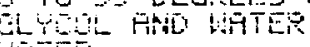

UTE

$\Rightarrow 0$ i 


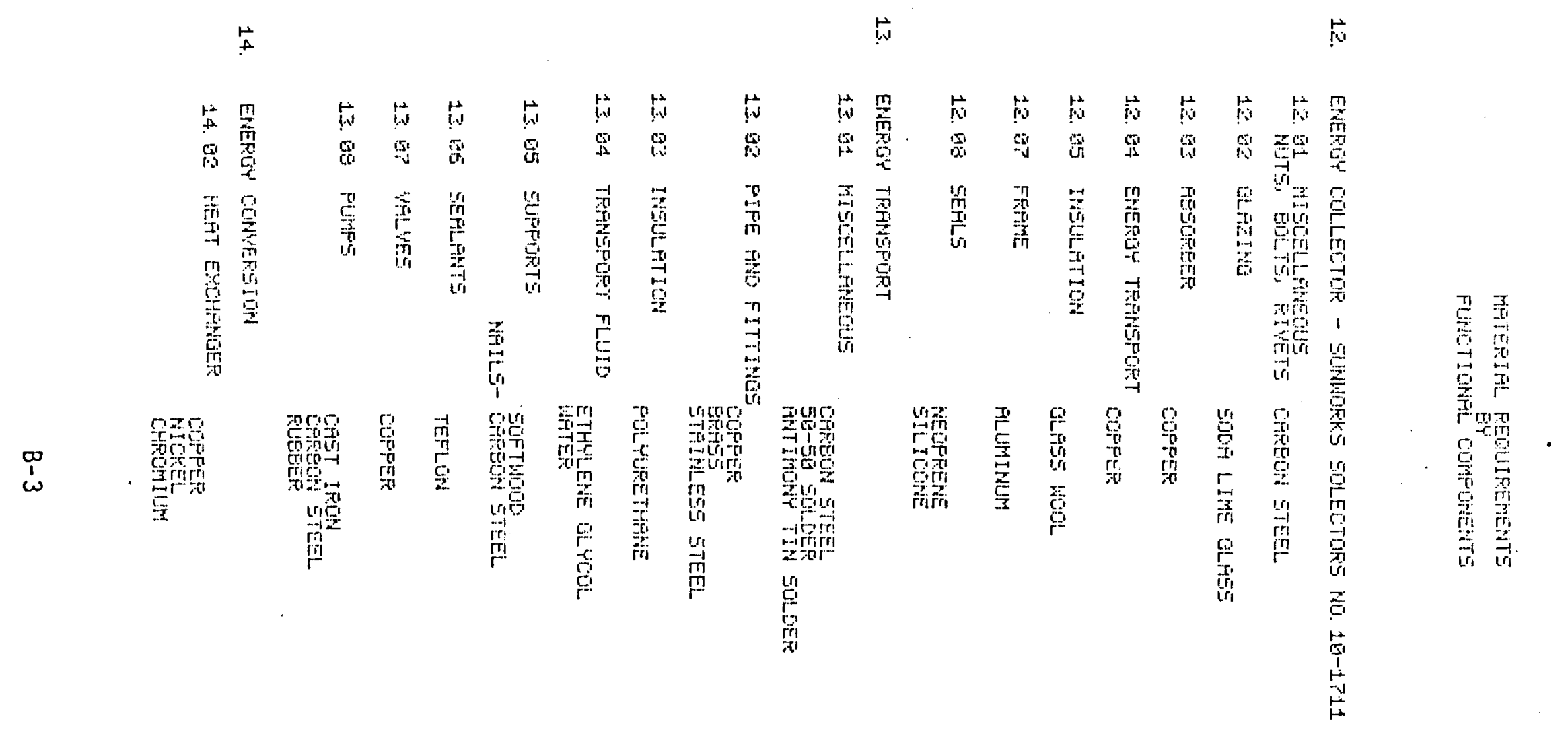

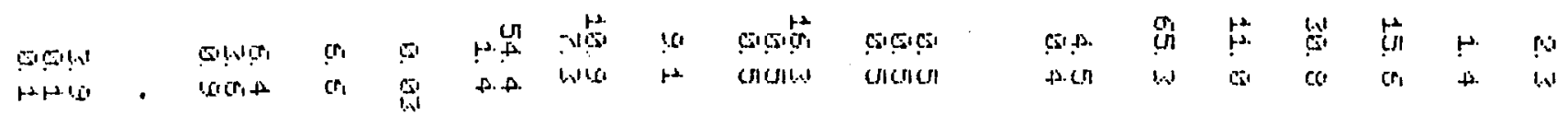


15. ENEFG'S STOFATIE

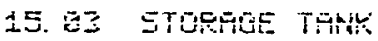

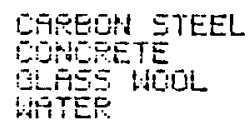

5.?.

4.

$\geq 00.6$

17. ENAEFI'Y SYSTEY COHTRULLLER

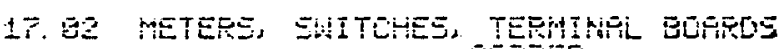

Cof

EO-40 SCLLER

$\frac{1}{3}$

Fiertot 
FOOTNOTES

12.07 - Estimated $0.7 \# / f t$ for aluminum exterior frame and cap.

12.08 - Assumed 2.25 \#/collector for neoprene. Estimated use of silicone sealant.

13.01 - Estimated weight of tefion tape, pipe anchors and solder.

13.02 - 1/2 inch ID copper pipe 100 feet.

1 to $1 / 2$ inch ID cu pipe adapters (8).

$1 / 2$ inch ID cu T's (12).

$1 / 2$ inch ID cu ETs (12).

$1 / 2$ inch ID cu cross El (1).

$1 / 2$ inch brass unions $(6)$.

Estimated weights of air vents, pressure gages and thermometers.

13.05 - Used $2 \times 4$ 's for base shoe top and bottom with sufficient bracing to obtain the desired tilt angle on the collectors.

13.06 - Assumed use of 1 roll of Teflon tape for pipe joints.

13.07 - Assumed a11 valves are 1/2 inch brass with estimated weights.

13.08 - Expansion Tanks ( 2 required) 14 ID $\times 16$ long $\times 16$ gage galvanized steel. Assumed weight. 


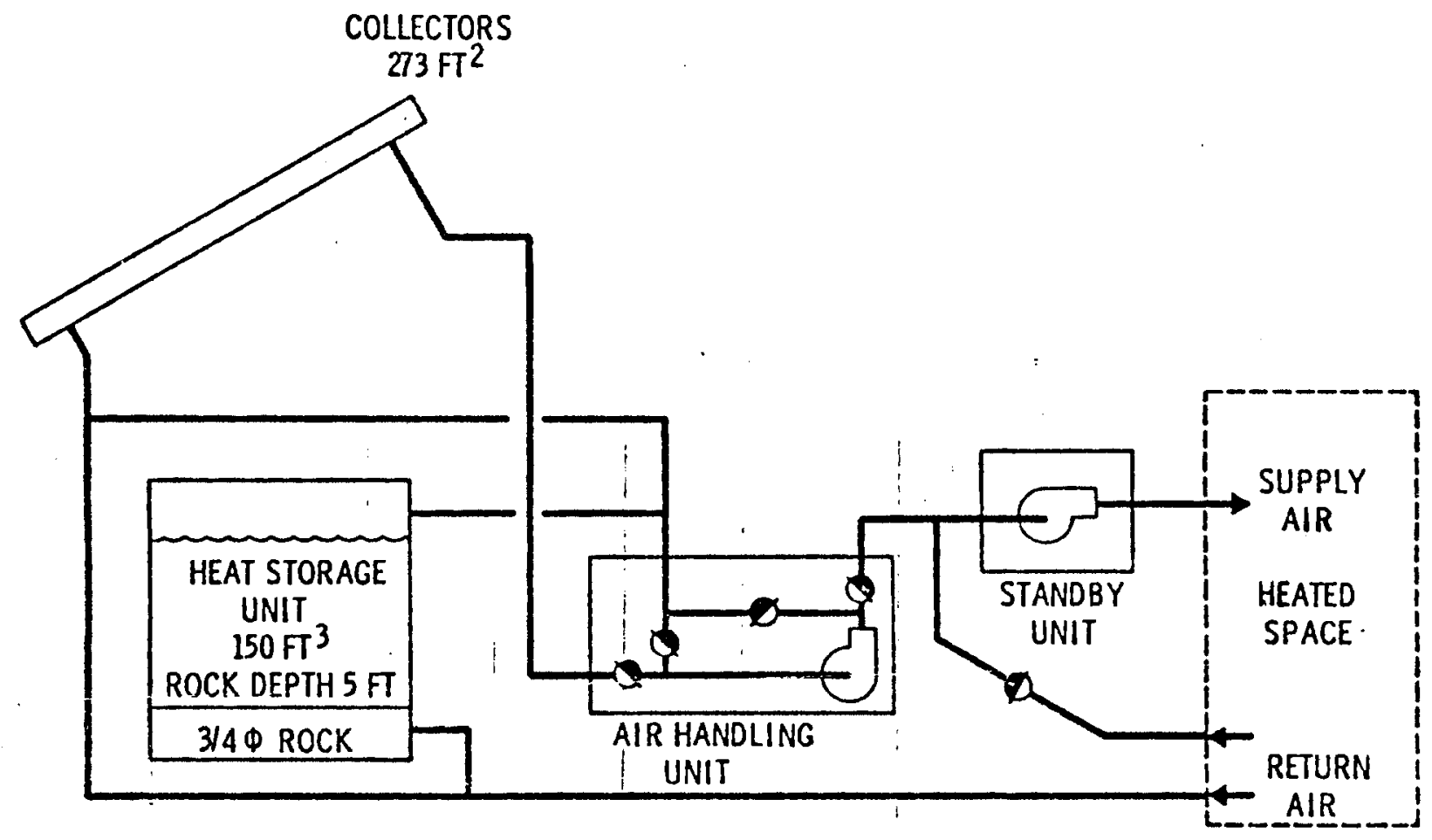

\section{SFFE HESTHE \\ SOLTHOATSTE \\ Westhetidn D.}

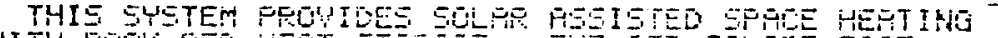

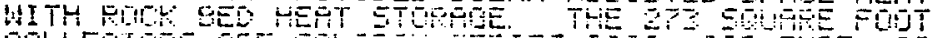

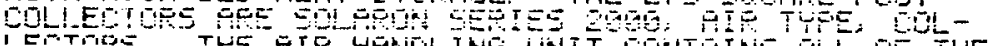

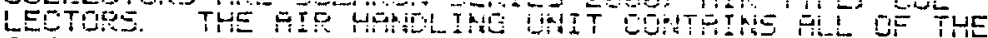

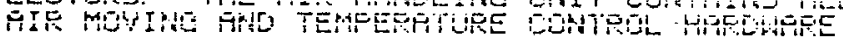

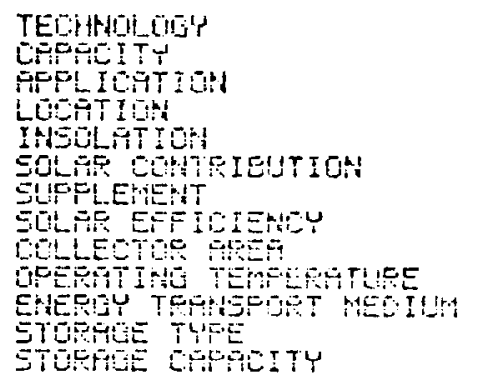

$$
\begin{aligned}
& \text { SHALOE: } \\
& \text { 4⿻ } \\
& \text { ERTE HETTRE }
\end{aligned}
$$

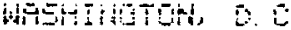

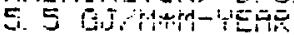

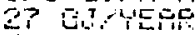

$$
\begin{aligned}
& \text { WATERE } \\
& \text { E. } 4 \text { mor } \\
& 915 \\
& =\mathrm{mT}
\end{aligned}
$$




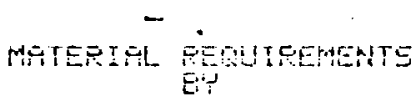

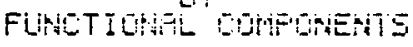

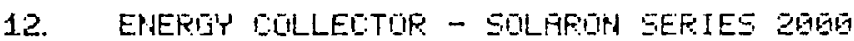

12. 51 MISCLIBEDUS

SOFT WOOD

4.9

CHEETR STEEL

527.6

12. GE GLEDINE

SOUA LIHE PLLASE

공

CAEEOH STEEL

12. 분 DUCT

CAREGAR STEEL

7: 5

12. 95 IRELLETIOA

HLASE HOL

$4 \pm .5$

12. 97 FFARIE

CHREOH STEE

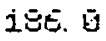

12.

EUTYL FLLEEER

EILICORE

E. 4

13. ERIERLY TEARIEFTET

1E. DUET

FPREOH STECL

441:

BIAlC

7. 5

13. 93 IHSLLATIOK

ULLFSS WOML

40.5

13. EU FARE

EUEFEF

COREOH STEEL

르는

FuL GEATUHATE

5.

5.

空

15. ENERI'Y STUATIJE

15. :97 FOCK SEO

PLPMOE

$=040$

Gis $=5$

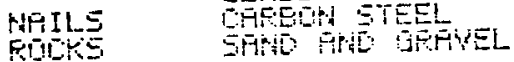

1ะ5.

115.

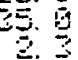

520.5

17. ENAERTYY SYSTEM COMATFOL

13. Q2 SUITCHES, METESS ETE

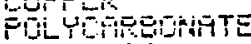

FHEROL1:

5.

5. 5 


\section{FOOTNOTES}

12:01 - Hood nailer frame-assume $1-1 / 2 \times 71 / 8$ inches $\times 68$ feet of lumber.

1.3.02 - Assumed 0.16 pound zinc per $\mathrm{ft}^{\mathrm{L}}$ of sheet metal. Sheet metal is 24 gage. Seventy-nine linear feet of $12 \times 14$ inch duct 13 linear feet 12 inch diameter duct. Eighteen Jinear feet of 14 inch diameter duct and 8 linear feet of $12 \times 20$ inch duct.

15.02 - Built from $2 \times 4$ studs with a $5 / 8$ inch plywood inner wall and a $1 / 4$ inch outer wall. To form the base, $2 \times 6$ !s are used. A steel screen holds rocks from falling into base.

17.02 - Assumed 3 pounds of controls in steel, copper, plastic phenolic, assorted things. Not defined now. 


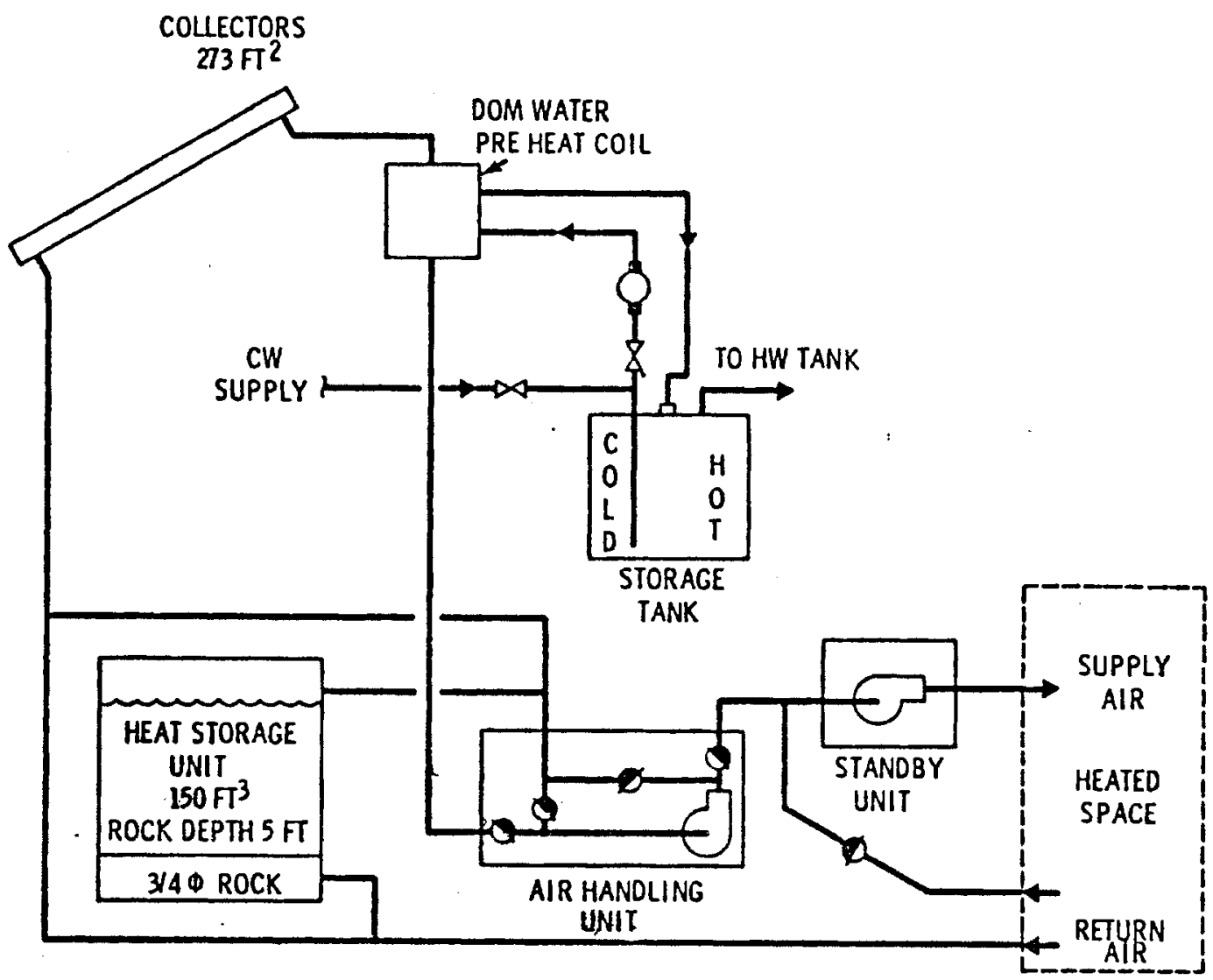

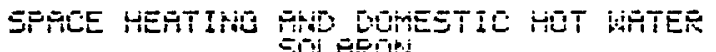
SLLFED:

HFEHIRTTGH, D. E

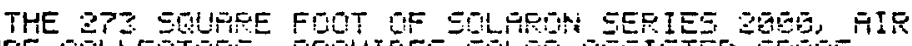

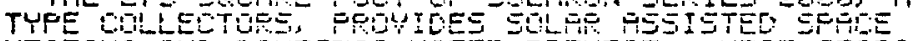

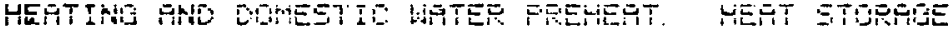

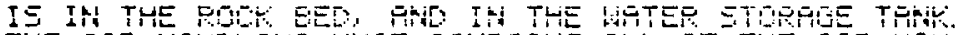

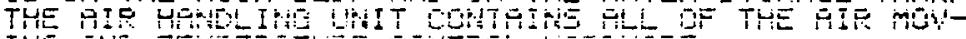

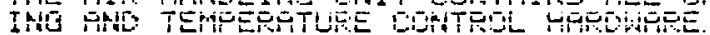

TECHNDLDGY

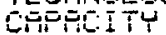

FFFI ICTIOTL

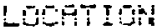

INSOLATIOAN

SOLPE WOHTIEUTION

GIJECLERERT

EOLFE EFTETEACY

COLLETTO FISE

OFEFTTHA TEMETETISE

EPILEDU TEGRERTET MESIUHA

ETCRETE TYEE

STEREGE CHESTTY
SHACOB

TE

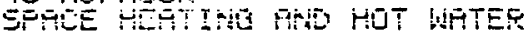

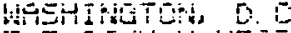

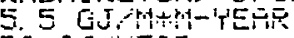

30 G.J.

YFIFELE

25. A Wittit

Fit

FICK FRID UATEP

E. 
15. ERERG' STISHGE

15. G2 FGOEED

Findidis

50710

CFEON STEEL

GLit: kugic

GHAD FHL GFEVEL

15. 93 HOT HETER STORPGE

CFEEON STEEL

JLFE WOMi
i巨E. $\overline{1}$

iis. 6

2

$\theta=0$

$6 \frac{5}{5}$

3.5

ต.

B- 11 
FOOTNOTES

12.01 - Wood nailer frames-assume 1-1/2 × 7-1/8 inches $\times 68$ feet of lumber.

13.02 - Assumed 0.16 pound zinc per $\mathrm{ft}^{2}$ of sheet metal. Sheet metal is 24 gage. Seventy-nine linear feet of $12 \times 14$ inch duct 13 linear feet of 12 inch diameter duct. Eighteen. 7 inear feet of 14 inch diameter duct and 8 linear feet of $12 \times 20$ inch duct.

15.02 - Built from $2 \times 4$ studs with a 5/8 inch plywood inner wall and a $1 / 4$ inch outer wall. To form the base, $2 \times 6$ 's are used. A steel screen holds rocks from falling into the base.

17.02 - Assumed 9-1/2 pounds of controls in steel, copper, plastic phenolic, assorted things. Not defined now. 


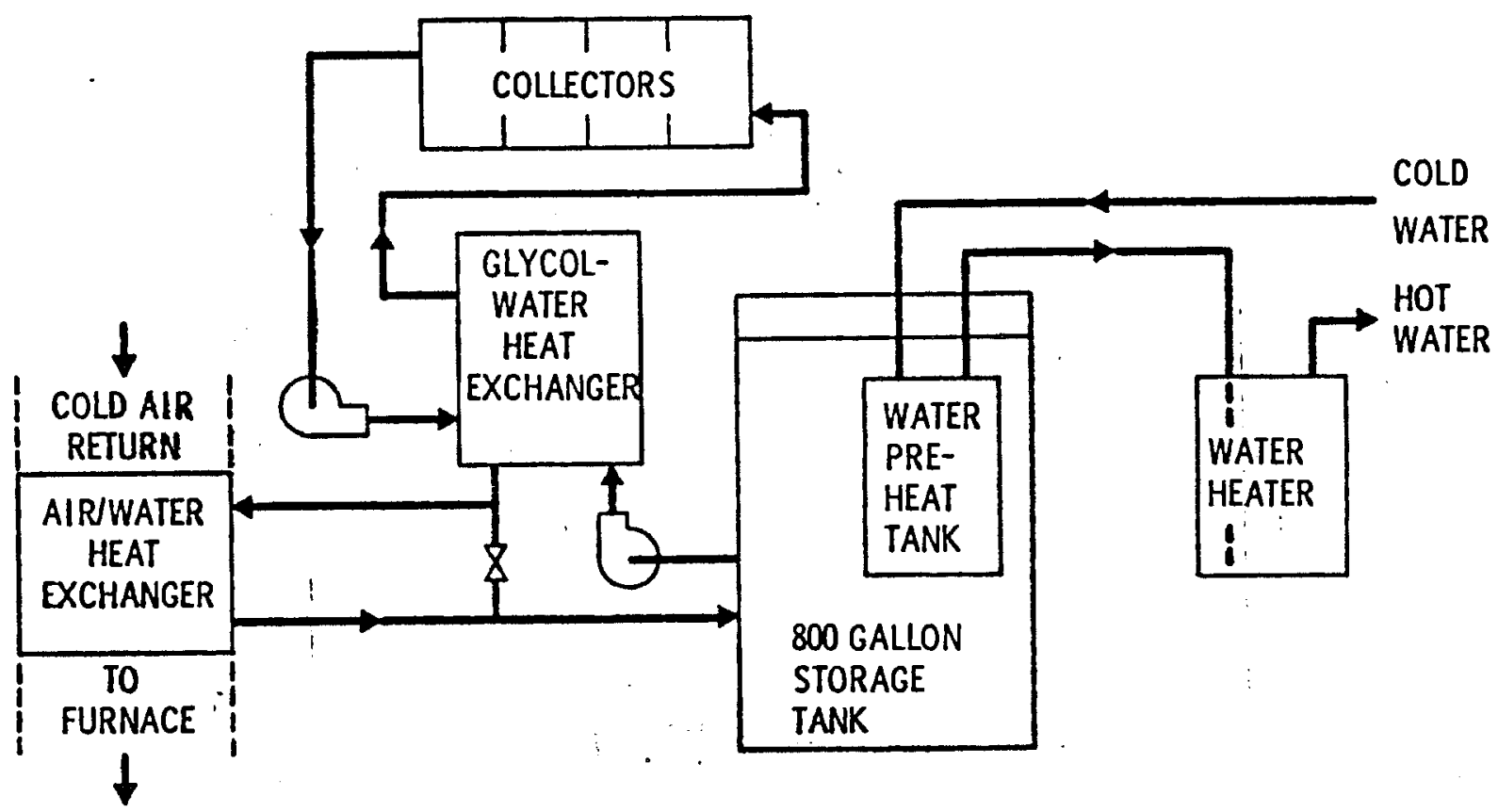

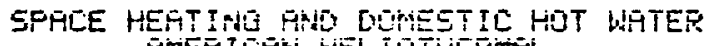
FHEFICAK HELIOTHEETLL

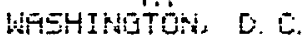

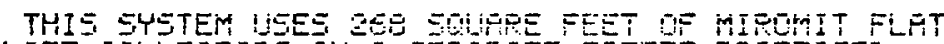
PLATE RLLETUES IN

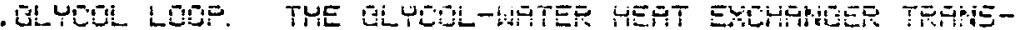

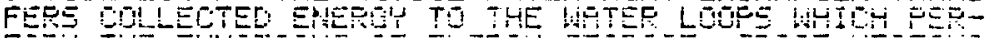

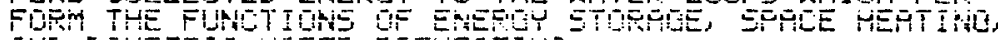

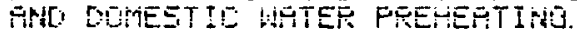

TECHNOLOGGY CAPRET T T

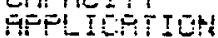

LOCTTITH

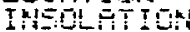

SULFE COHTRISUTIOH.

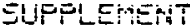

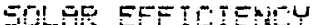

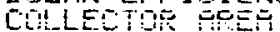

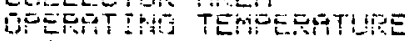

EAEEHU TEDSERT REOILA

ETCETLE TYES

ETUERE CFIEITY

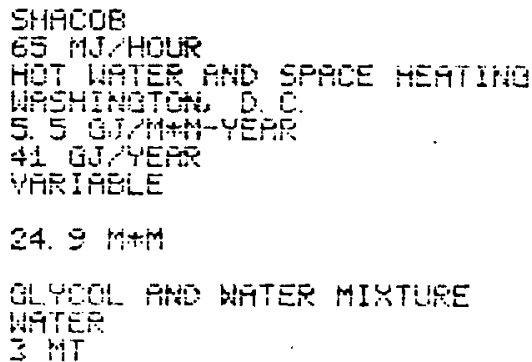

$24 .=m+m$

GLYTCL FWO HITES MISTISE 4T 


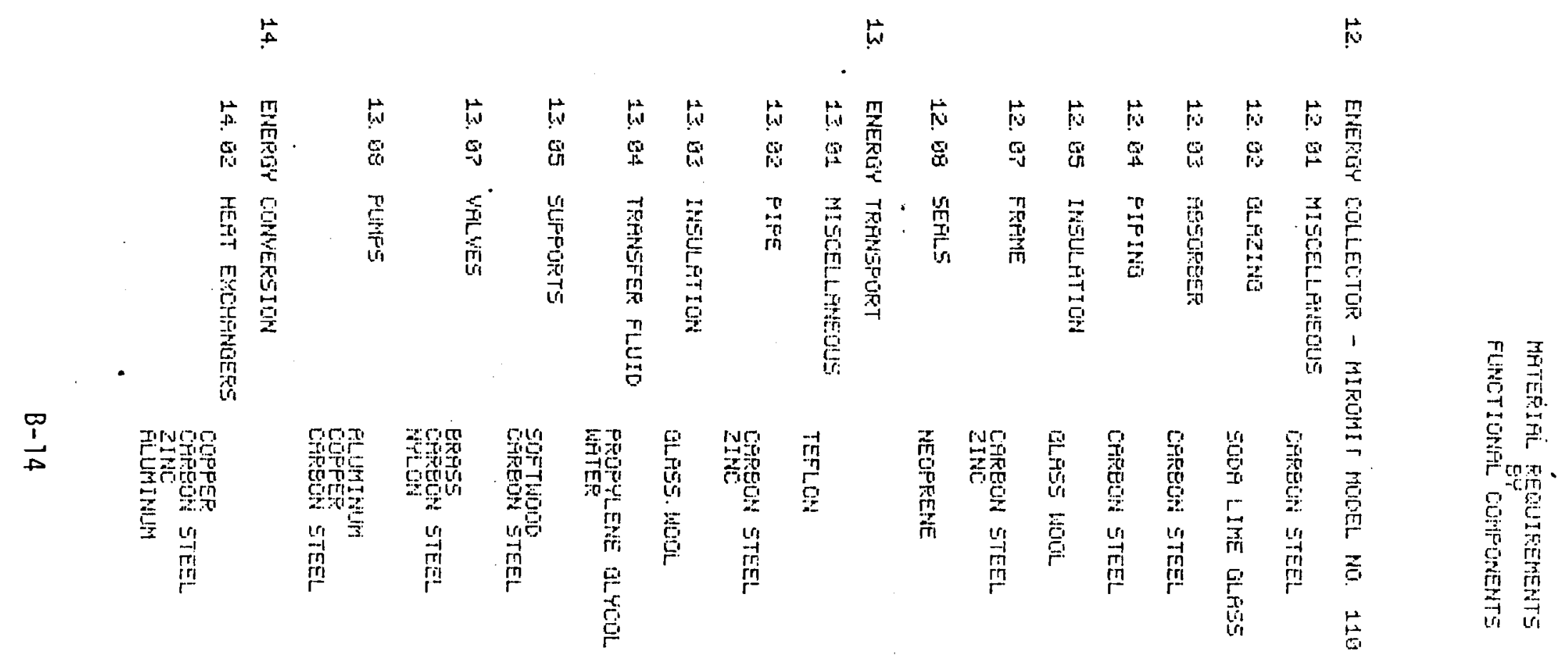

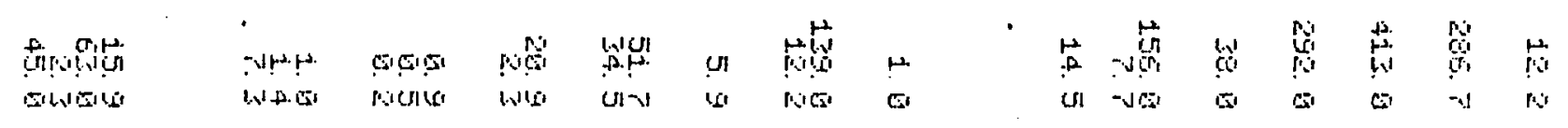


15. EREFIJY STUFRTIEE

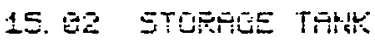

COPEDOH STELL

IIAE

WTE

ULES HOCL

584.9

i. 4

$\exists i \frac{1}{6}$

2.

17. ENEFIOY STSTEM CONTFLLLE

CUTPE르

1.

CHU STEEL

FLUMiriunt

1.

9.5 


\section{AMERICAN HELIOTHERMAL}

\section{FOOTNOTES}

12.01 - Assumed steel screws and bolts, ignored platings.

12.07 - Used dimensions of the topless box to calculateweight.

13.02 - Base the zinc weight upon difference in weight for black \& galvanized pipe.

13.04 - Assumed a minimum wood frame to assemble and contain heat exchange and pumping equipment.

13.08 - Weight is given from Sunstrand "L" model pump.

14.02 - The glycol/water heat excinanger is copper tube (coiled) inside steel tube counterflow type. Seventy-two inches of steel 5" diameter tube around 72 feet of 5/8 copper tube. The water/air heat exchanger is half iron and aluminum.

15.01 - For the 800 gallon storage tank use $4^{\prime}$ diameter, $8^{\prime}$ tall with .250" steel wal1.

15.02 - Assumed 6" insulation around the 800 gallon tank. 


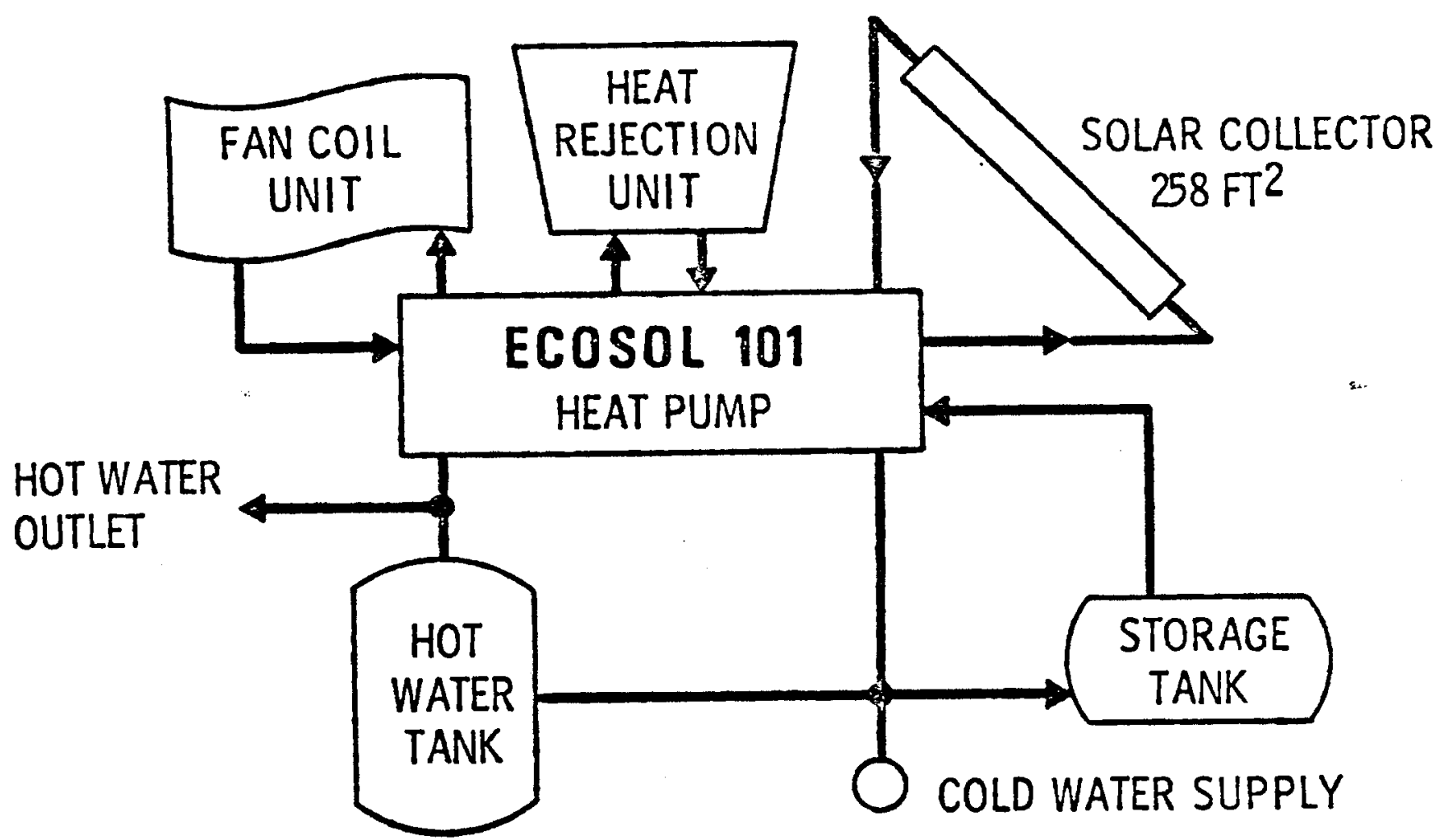

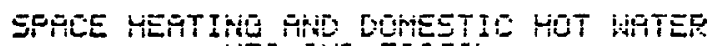

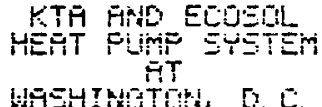

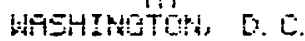

THE SOLFP BSEISTED HEFT FUW STETEM SHOWW IN THE

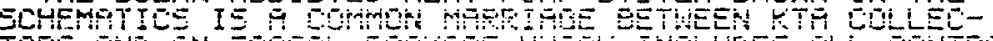

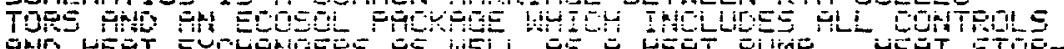

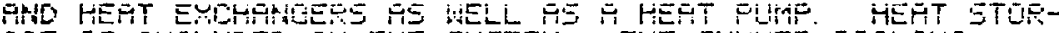

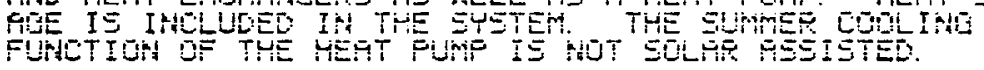

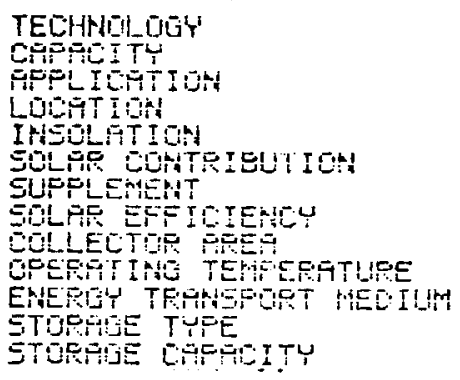

SHALOB

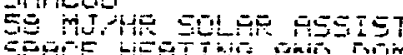

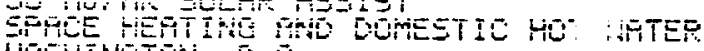

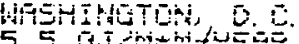

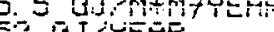
ELECTPIE

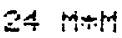

낸ㄷㄴ동

ב. $\$$. $1 T$ 


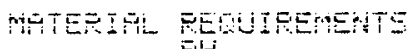

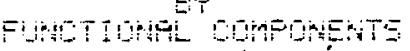

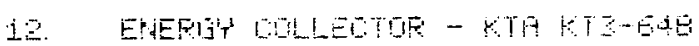

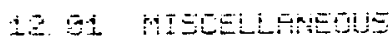

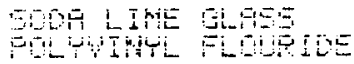

30

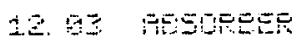

OPEE

$19-\frac{i}{1}$

420 bithe

OAFEF

27.2

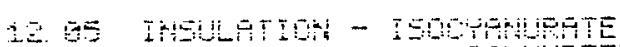

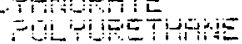

5.4

12. 75 PEFLETOE

GLES

9. 3

12. QP FEME

Btominition

고

isi. +4

12. EREET TREABUT

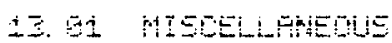

$50-505000$

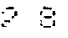

12. 02 ping

OPEET

15.4

IE GE THEDTHEA

PLLTHETHATE

9.

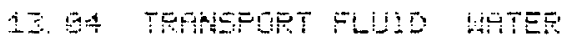

25

129 YTLYES

5055

is.

i4. EPEETY COHVESIOHA

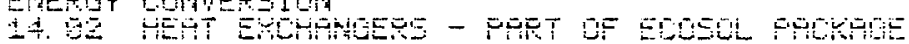

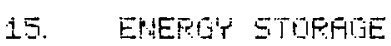

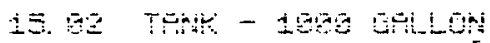

PEDA STE단

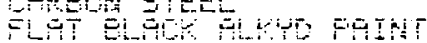

COMTETE

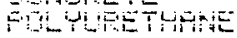

MiT:

8.

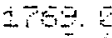

30

17. ERESH GSTED OOHRALEF

bog

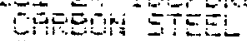

Geve

Aisinition

G

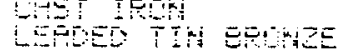

Eim

500

niting

$-20-140=$

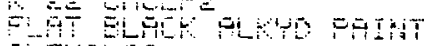

$=0$

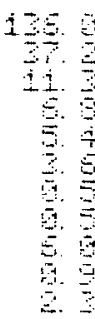




\section{$\underline{\text { KTA-ECOSOL }}$}

\section{FOOTNOTES}

12. Energy Collector

12.02 - Use two concentric tubes each 0.008 inch thick, $0 D=1.5$ \& 0.5 inches, 28 tubes per collector. Include endcaps of glass. Tedlar is 0.004 inch thick.

12.04 - Use 1/2 inch copper manifold top and bottom - guess.

12.05 - Use $3 \times 3 \times 46$ inch block top and bottom.

12.06 - Use half silver 1.5 inch diameter, 0.00004 inch thick.

13. Energy Transport

13.02 - Use $3 / 4$ inch copper to run to collector (40 ft.), evaporator (10), condenser (10) and domestic hot water (10 ft). Use one inch copper to storage tank $(20 \mathrm{ft})$. Use $1 / 2$ inch copper between storage tank and expansion tanks ( $4 \mathrm{ft}$ ).

13.03 - Insulation - use $3 / 4$ inch on all piping.

13.04 - Assumed 70 pounds water.

13.07 - Assumed 11 valves at 3 pounds brass each.

13.08 - Pumps included in ECOSOL Package.

15.02 - Assumed $6 \mathrm{ft}$. diameter, 4-12 ft. tall - 0.25 wall steel. Assumed a concrete footing $6 \mathrm{ft}$ diameter - $1 \mathrm{ft}$ deep. 


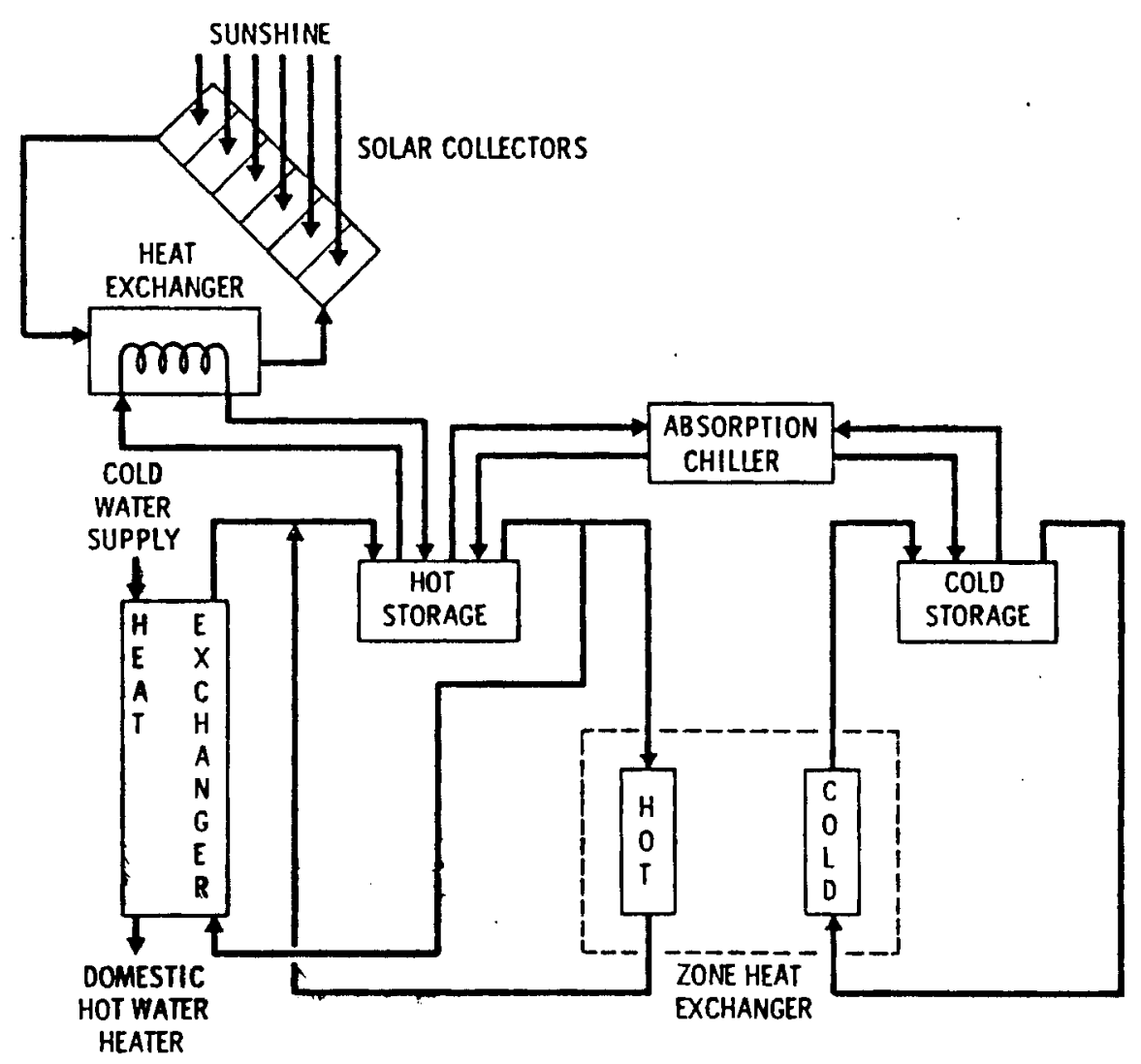

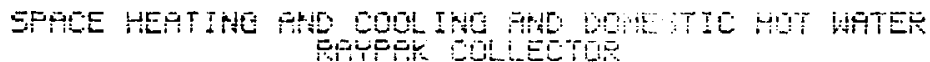

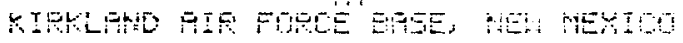

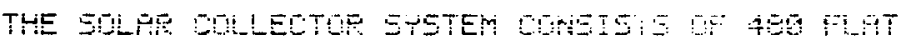

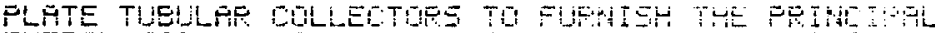

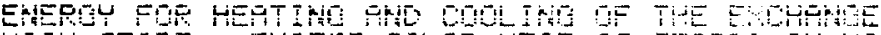

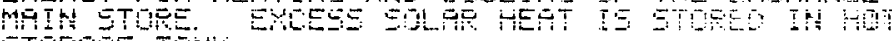
STGQTE TEN

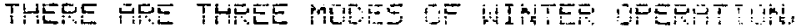

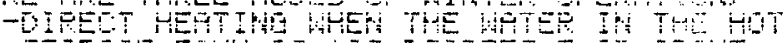

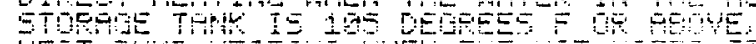

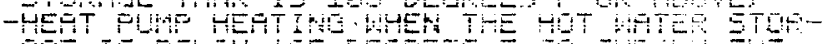

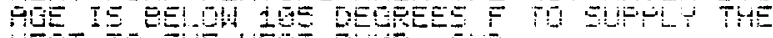

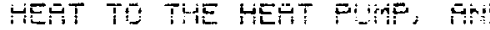

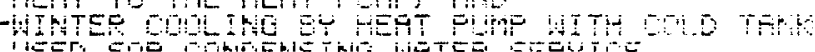

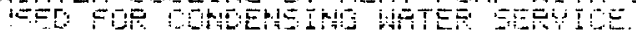

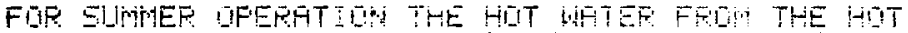

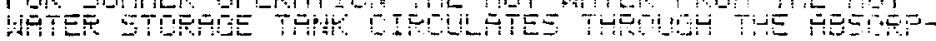

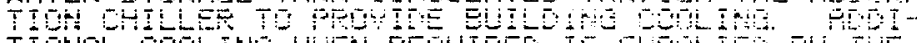
TIOHO COU

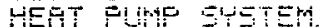

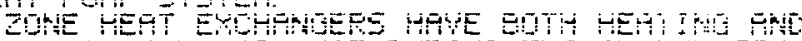

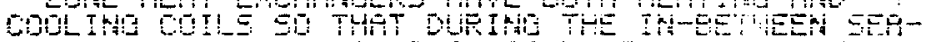

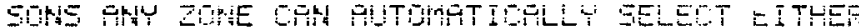

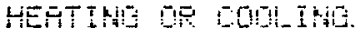

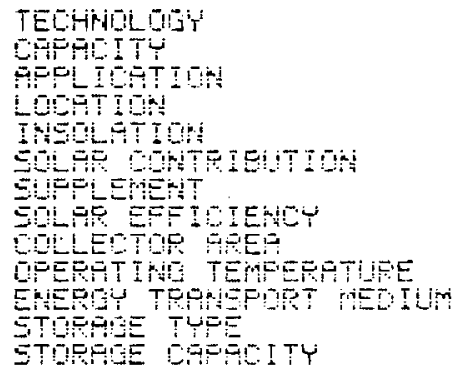

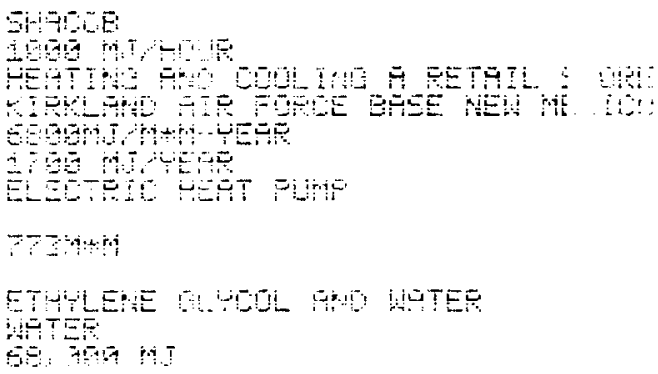

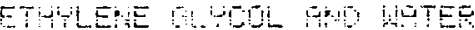
HT

60.10 a 


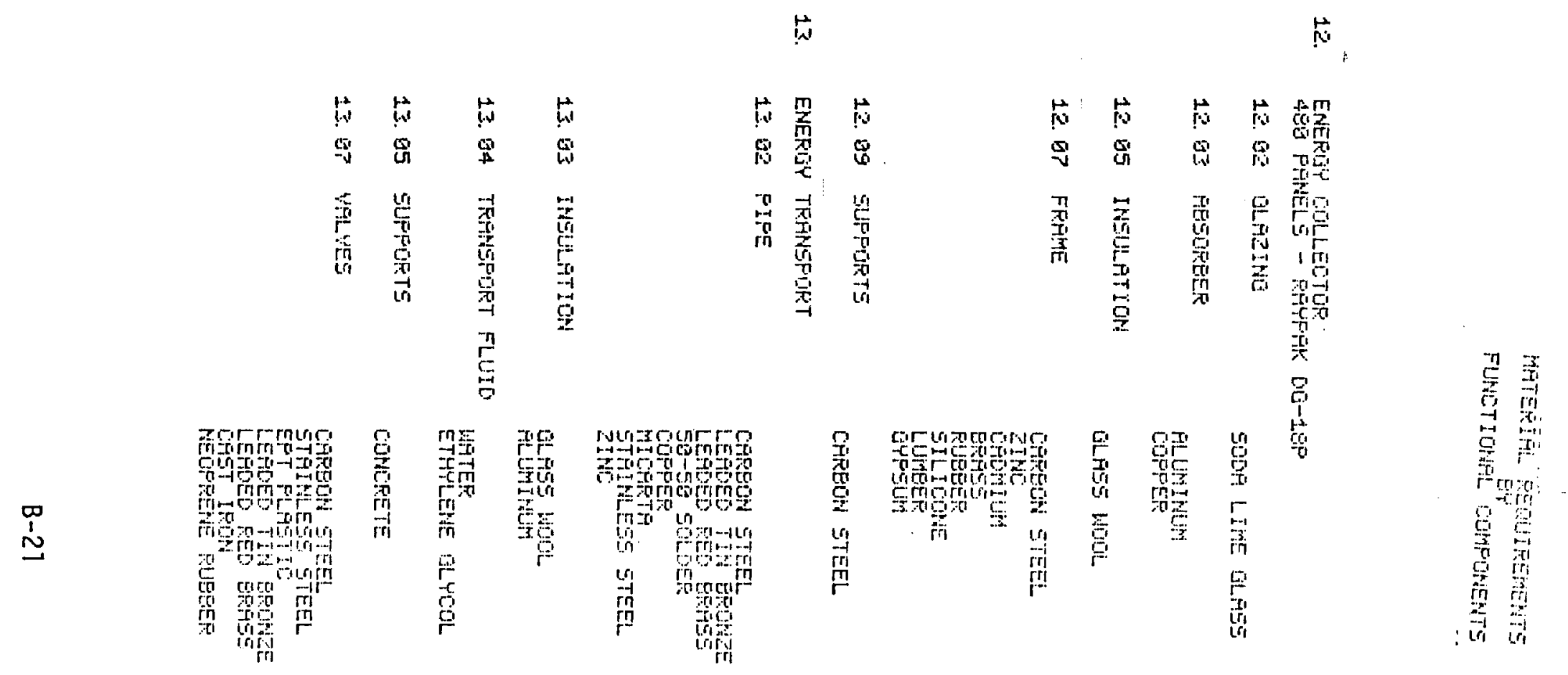

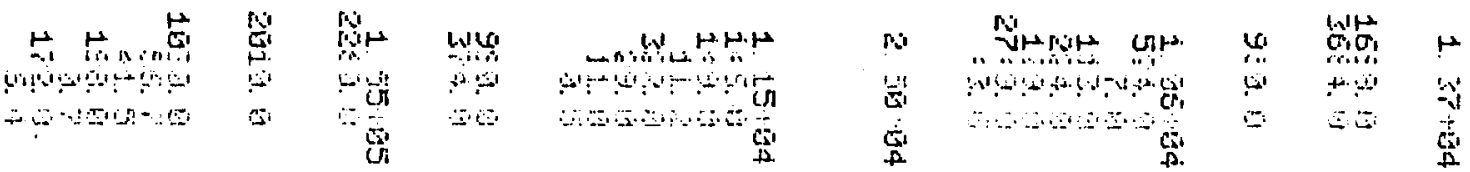




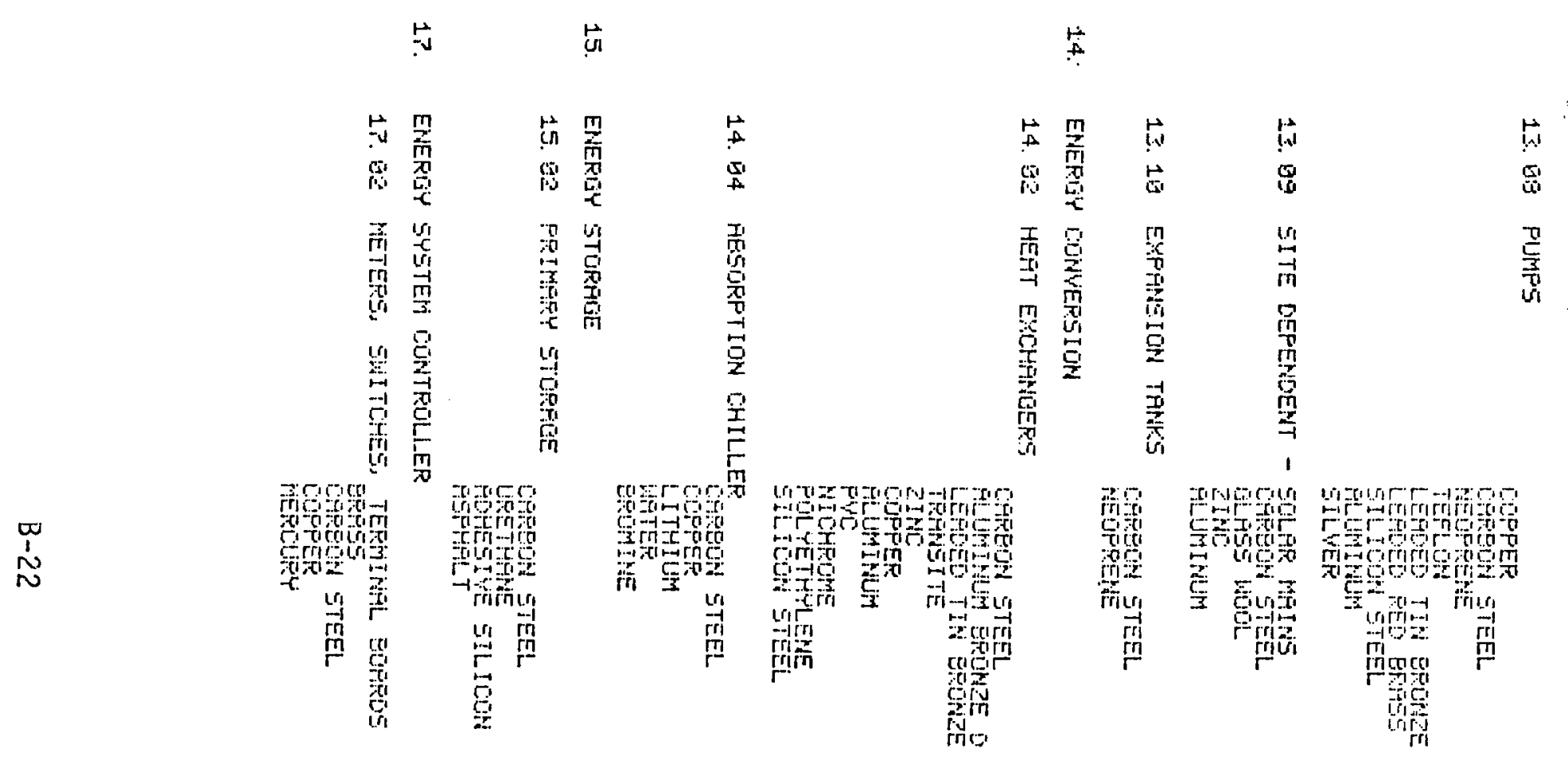

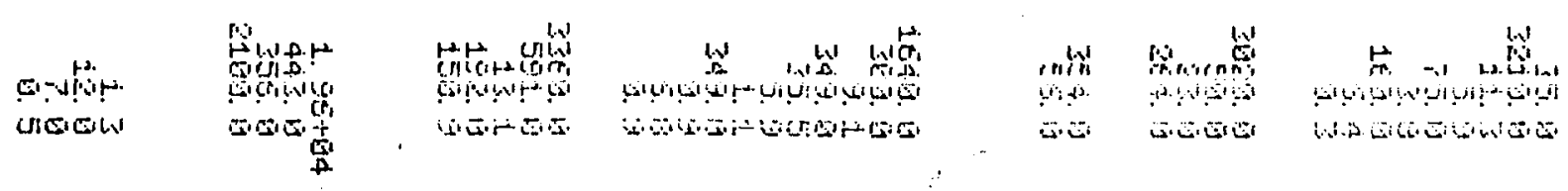


FOOTNOTES

13. ENERGY TRANSPORT

A number of the components of the energy transport system provide dual functions and thus cannot be assigned wholly to either the solar system or to the basic system. In order to overcome this problem, the cooling tower and its circulating pump CP2 were considered part of the solar system. Heat exchanger HEl and pumps CP5 and CP6 were considered part of the basic system. The heat pumps F/HP1 and F/HP2, pumps CP7 and CP8 and the domestic hot water system were considered parts of the basic system.

13.02 - PIPING

As a matter of economizing on materials and labor the solar panel header and piping were placed on the surface of the roof. Roof penetrations for pipe were reduced from 320 to 4 .

13.04 - Ethylene glycol solution was estimated at a 50-50 volume percent.

13.07 - Weight of EPT plastic in butterfiy valves was estimated.

13.08 - Weight of ethylene glycol feeder system components was estimated. 


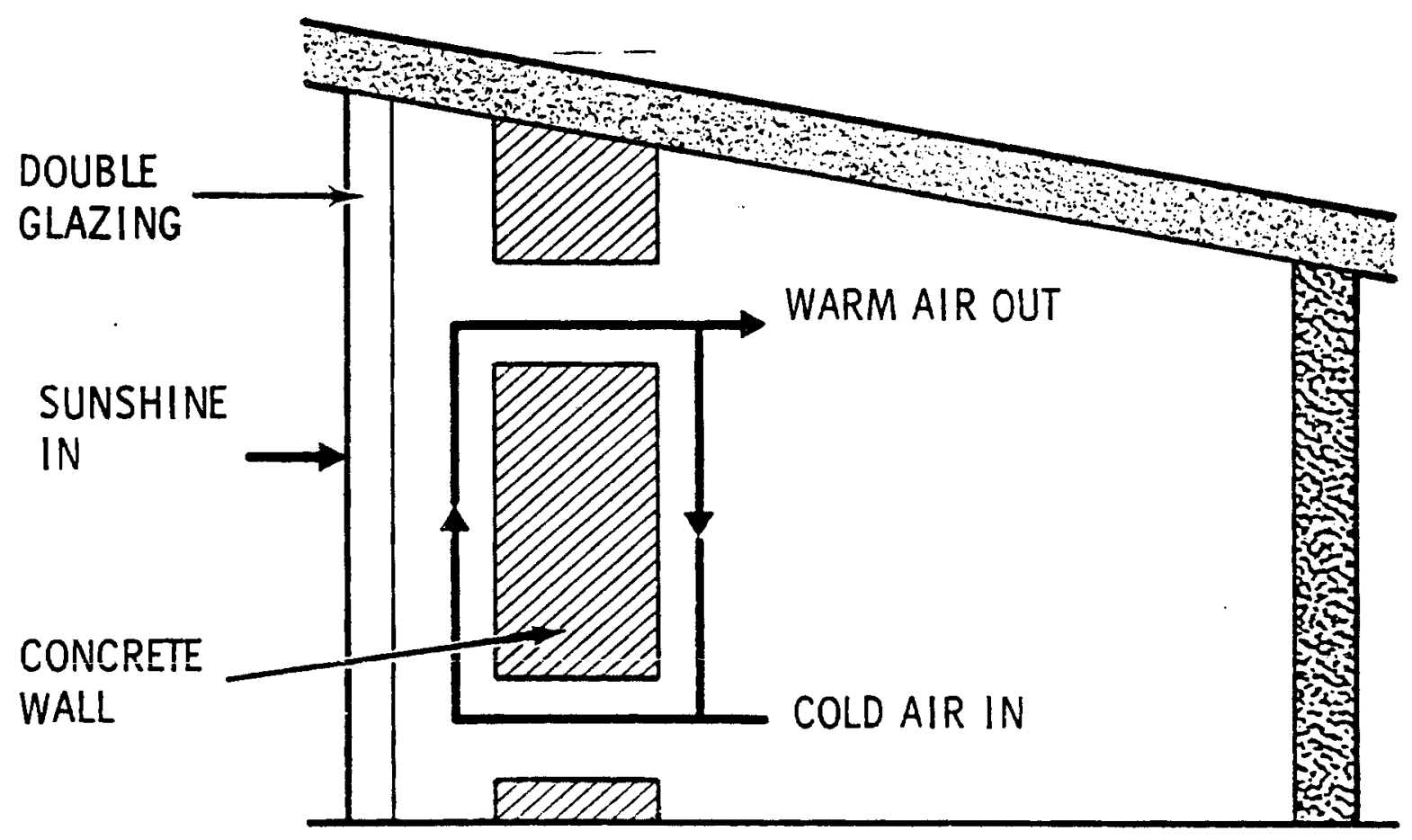

\section{PESUE GFE HETTH

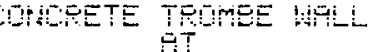

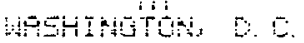

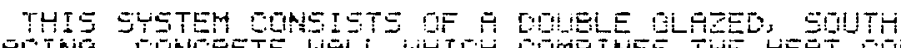

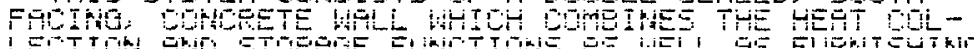

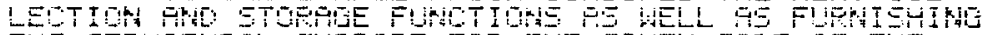

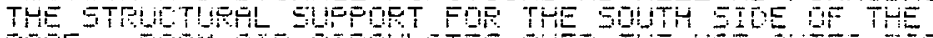

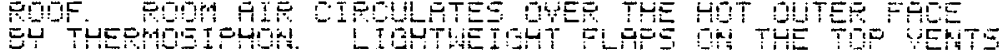

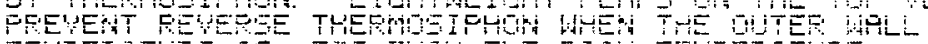

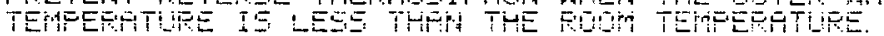

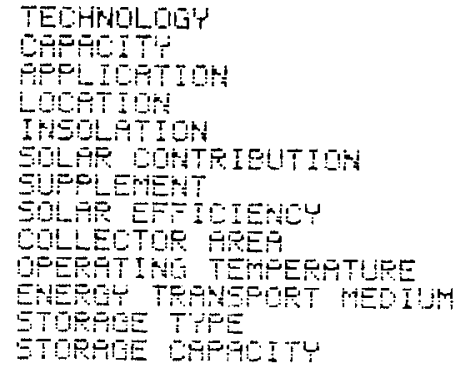

TEEHMOLLIG'

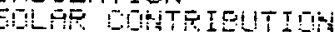

Gipen

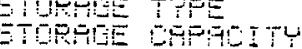

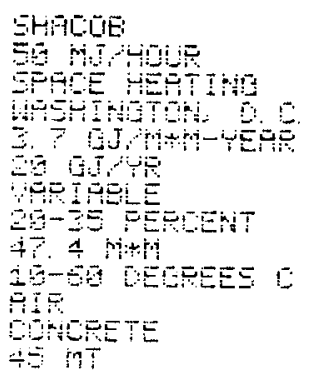




$$
\begin{aligned}
& \text { MATEEIAL FEDUIFERANTS }
\end{aligned}
$$

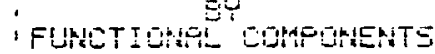

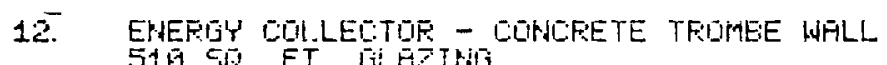

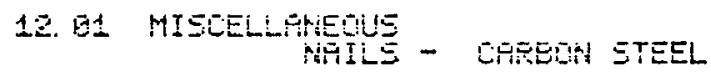

క.

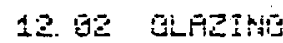

SOOM LIME GLHES

746. 6

12. GZ FESOEECP

WHLL PBIO FOUTINGS

REIMFCETIRU EER

COHEFTE

CFEERN STELI

FLAT ELFES HLYTO FAIRT

4. $12+\overline{6} 4$

520.9

236

12. DTP FEATE - WIHDOWS

FilunINHUm

145. 5

13. GS SEALE

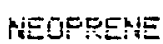

1.1. 3 


\section{FOOTNOTES}

10. - Rules of thumb used in sizing Trombe wa11: Glazed Trombe wall area equal to half of floor area, wall thickness - one foot, and double glazing. $1024 \mathrm{sq}$. ft. floor area assumed.

Solar contribution estimated from Nashville, TN data given by Balcombe et a1, "Passive Solar Heating of Buildings", at Workshop on Solar Energy Applications, Associated Universities, Inc. June 27 through July 31,1977. Approximately $65 \%$ solar contribution.

12.03 - Trombe wall also supports south side of roof. 


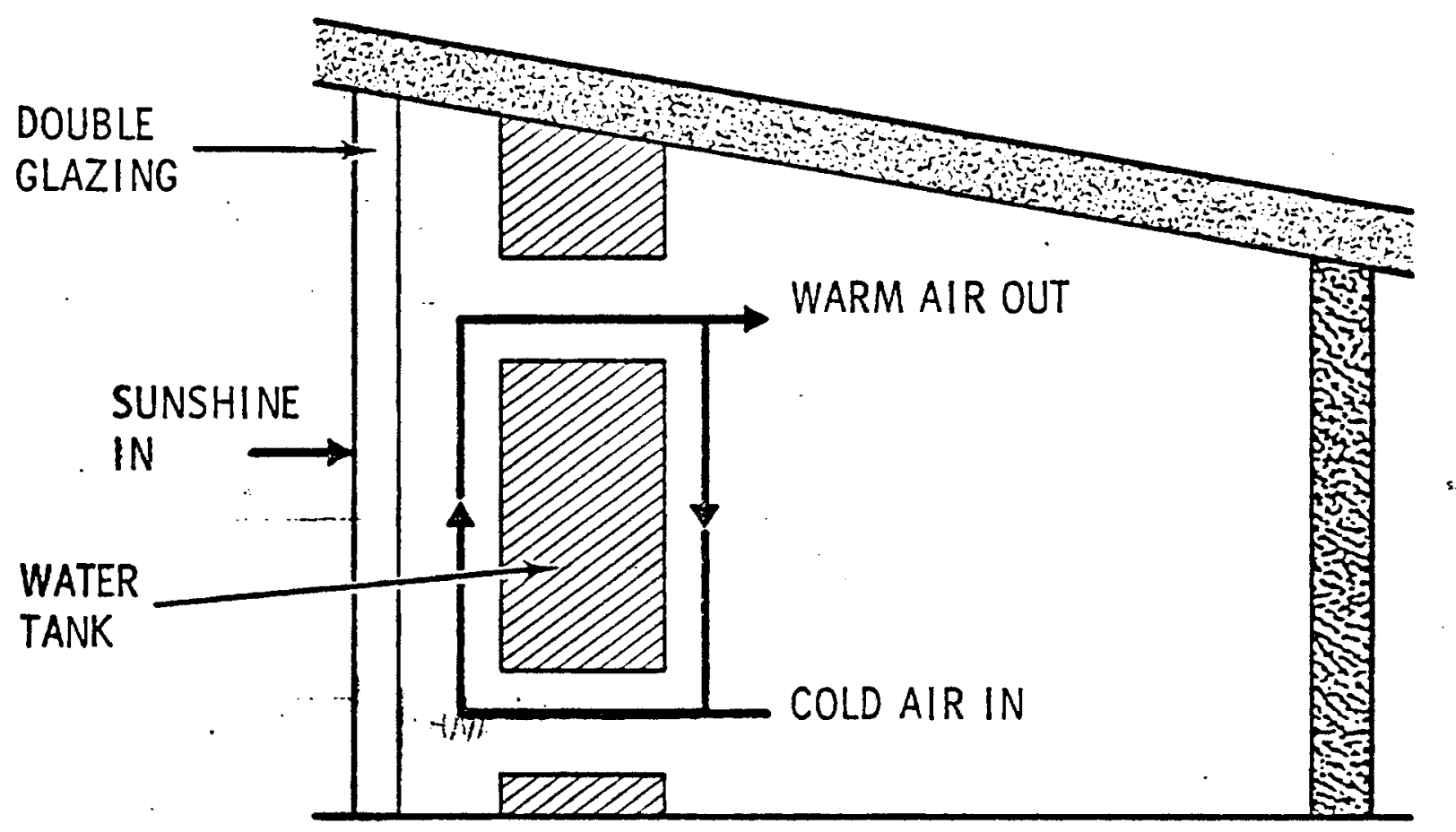

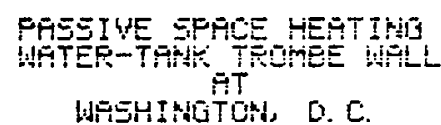

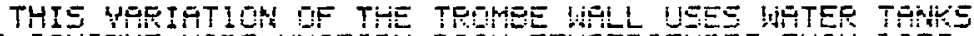

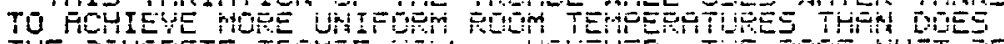

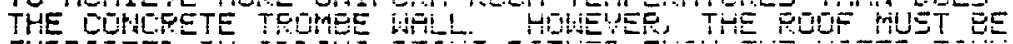

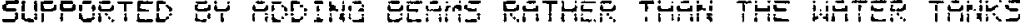

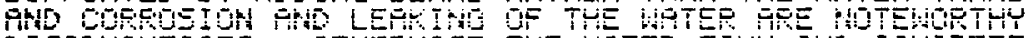

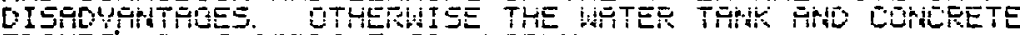
TROHEE WFLLE GFEFATE SIMILERLY.

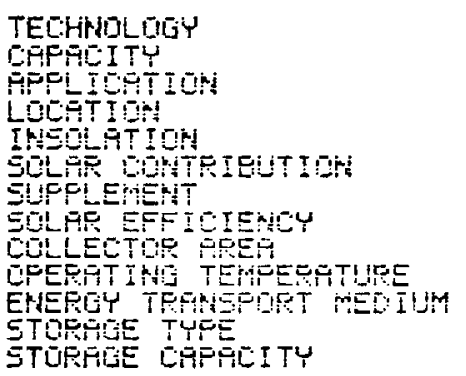

SHACOE

56 17T HULP

SPCE HET IMS

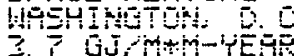

UTHET

HTiPL

$29-35$ FECENT

47. A1mith

1D- TS DEGEES

Fis

HETER

‥ 2 MT 


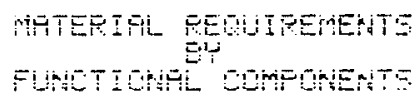

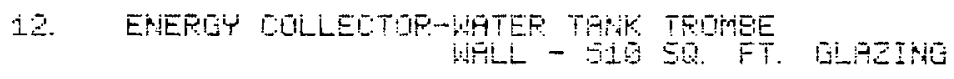

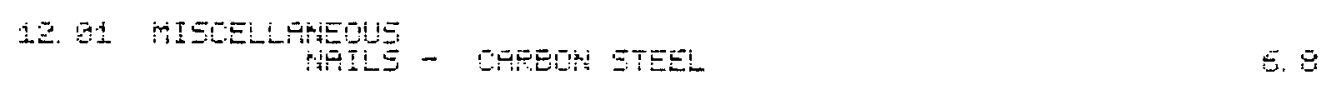

12. Ge GLETHE

EOCP LIME GLASS

746.0

129 HESOREER - MHTER TEKKK

TENon =TEE

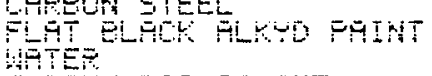

GDTHW DICHEMTE

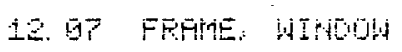

FiLimiging

250
720

1.45. 9

12. 55 SET:S

MEOFERE

ii. 3

12.69 Sypptipts

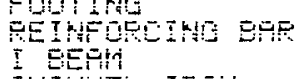

OHANHEL IFUN

GopeT

305

5.2

S4. 
FOOTNOTES

10. - Rules of thumb used in sizing Trombe wa11:; glazed Trombe wall area equal to half of floor area, six inch wall thickness, and double glazing. 1024 sq. ft. floor area assumed.

Solar contribution estimated from Nashville, TN data given by Balcomb et al, "Passive Solar Heating of Buildings", at Workshop on Solar Energy Applications, Associated Universities, Inc., June 27 through July 31,1977 . Approximately $65 \%$ solar contribution.

12.03 - Corrosion inhibitor - $0.1 \%$ sodium dichromate assumed.

12.09 - Supports required are for the south side of roof and for the water tank. 

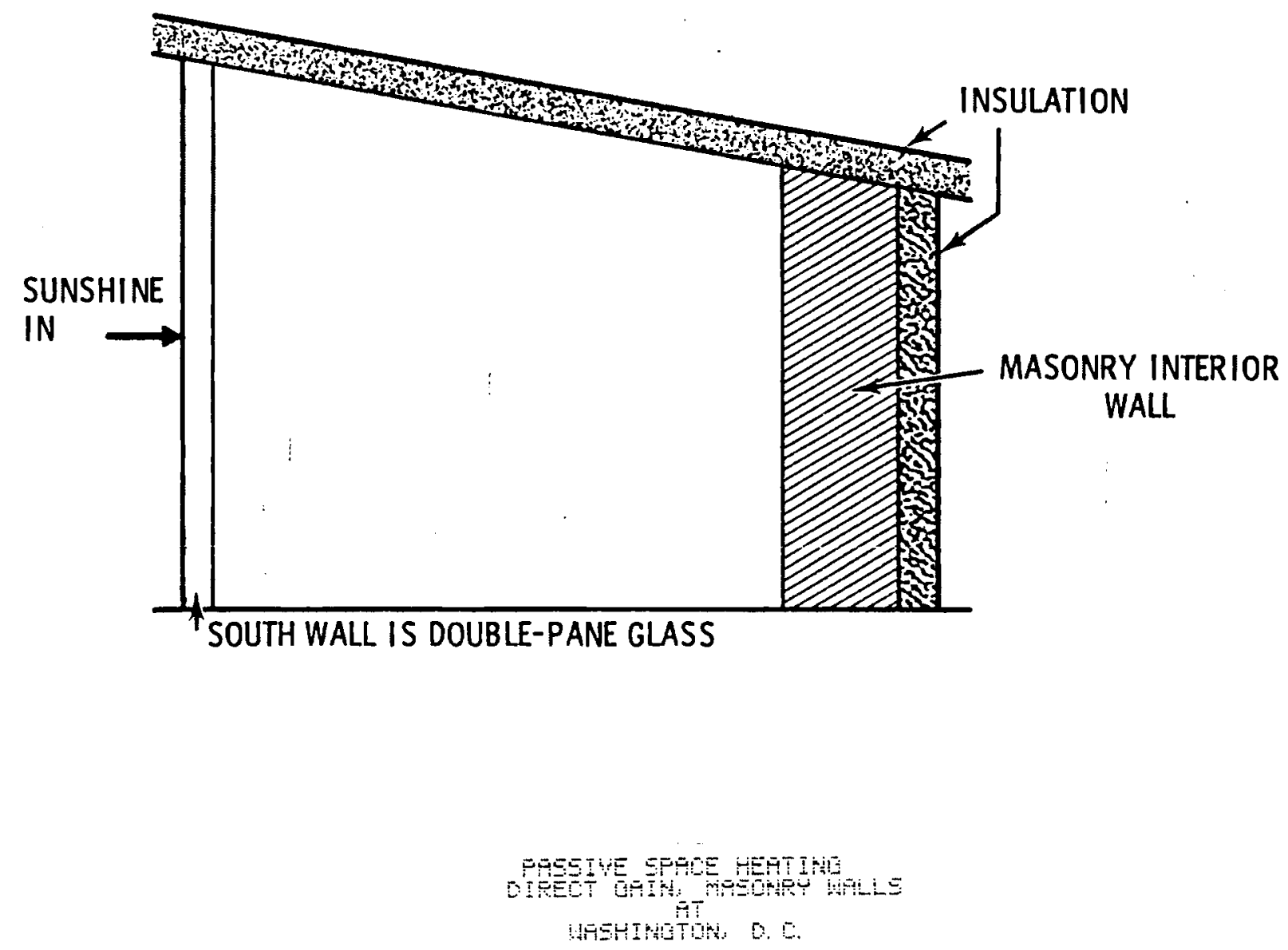

TECHRATLER'

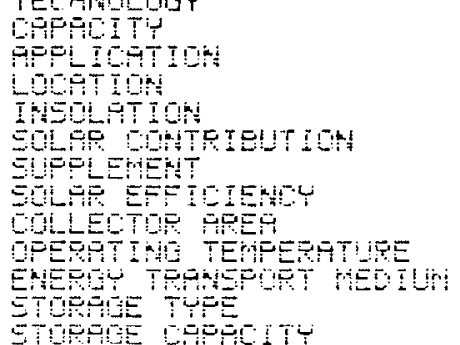

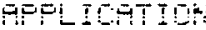

LOC IOA

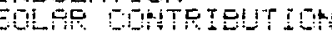

ateon

ETPGOE

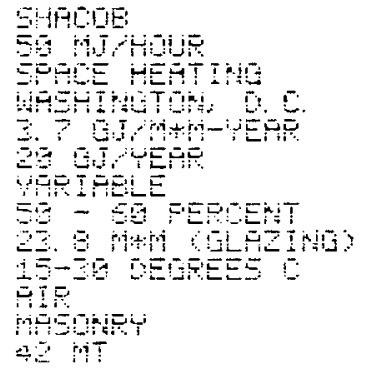




$$
\begin{aligned}
& \text { MÄTERIEL EEOUITEMENTS } \\
& \text { FUNCTIOHFL CONFUHEATS }
\end{aligned}
$$

\begin{tabular}{|c|c|c|c|}
\hline 12.51 & 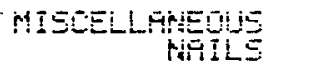 & CAREOH STEEL & 5. 4 \\
\hline 12.87 & GLAEIKLIT & SOLS LIME GLAES & 37.6 \\
\hline 1: 93 & 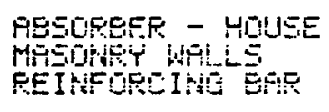 & WELE' & $\begin{array}{l}4.9154 \\
341.9\end{array}$ \\
\hline $1: 97$ & FREME, HINOUW & FiLLirítrium & $7 \pm 5$ \\
\hline 2. 35 & SEFLS & REQPREKE & 5. 9 \\
\hline
\end{tabular}

12. ERERGY COLLEOTOR-HOUERLALLS GLARING 


\section{FOOTNCTES}

10. Rules of thumb used in sizing direct gain: glazing area equal to one-fourth of floor area, four inch wall thickness, absorbing wall area equal to six times glazing area. $1024 \mathrm{sq}$. ft. floor area assumed.

Solar contribution equivalent to Trombe wall with twice the glazed area. Contribution estimated from Nashville, TN data given by Balcomb et al, "Passive Solar Heating of Buildings," at Workshop on Solar Energy Applications Associated Universities, Inc. June 27 through July 31, 1977. Approximately $65 \%$ solar contribution. 
$\stackrel{\omega}{\omega}$

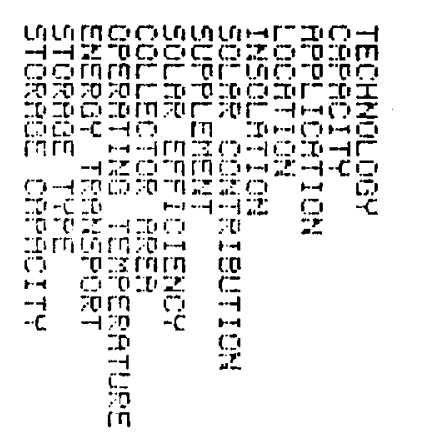

(a)

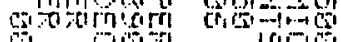

in

is

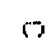

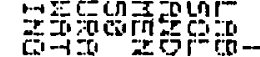

rn $2 \pi=-1$ -

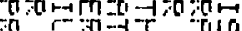

$0,-1=0$

in $z_{2=1} \geq 2=0$

(n)

$\tau$ is $r$ in

Ear on

so 0 ing

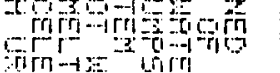

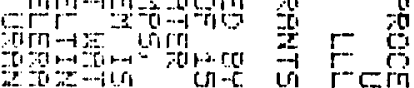

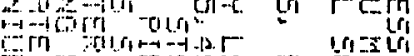
and

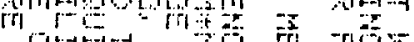

(1) की winctiong ot

$x+10-100$

Ir iri

irrer

if

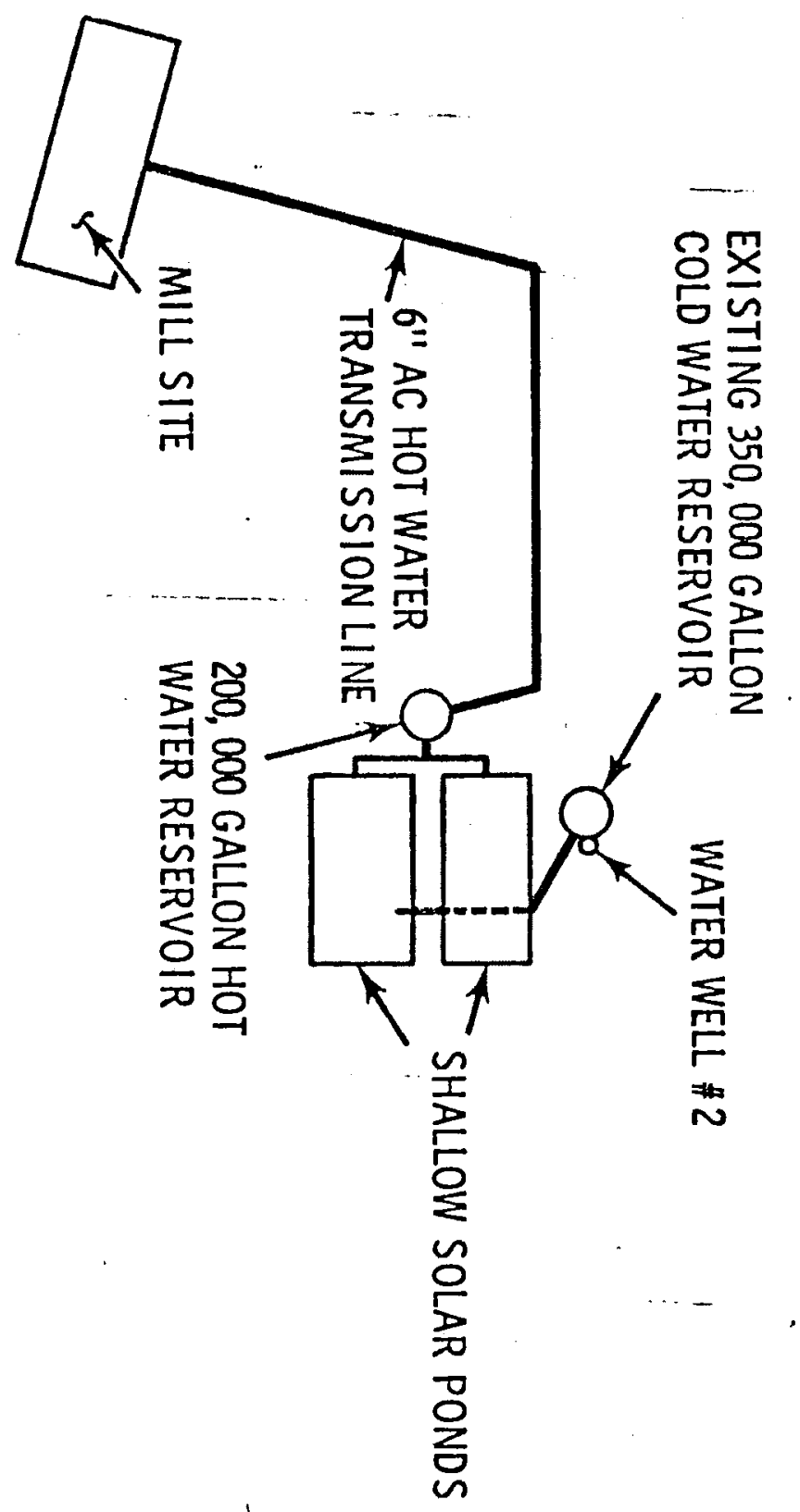




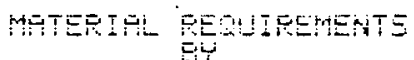

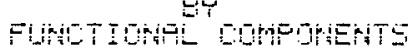

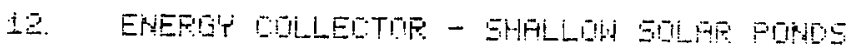

iz.

$2=$ A5 THEULETIOH

12 W FPHE

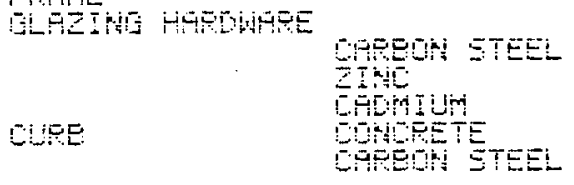

A. 95 SED:

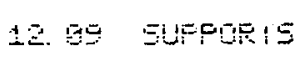

12. BE HESOEET
MEETHAHE

EAnit

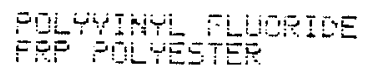

PYi:

AOT TME JLSE

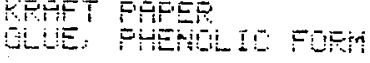

CPEOA STEEL

Gonjum

EREG ETEL
50.5

$2.9+94$

1002

3

10

$50+9+$

$1+95$

5

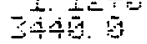

i.5. 5

$9.9+55$

9650

2.0

DET ETEE

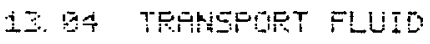

WTER

2. $5+36$

1297 MULS

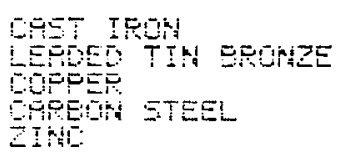

12. EE FintF

CET TETH LEETES TH BORME UEm $=15$

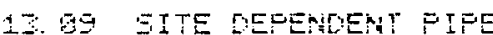

TEATHETTE

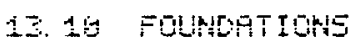

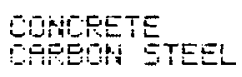

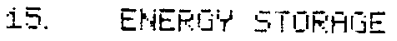

15.

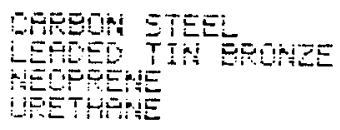

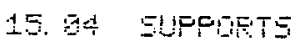

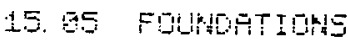

Exide

M문드는
1209
0.5
0.5
0.5
05

7 현.

15

3

2. $25+90$

8259

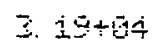
ㄷ. $\frac{1}{8}$ 130

5. $94+94$

$1 \pm 5$ 
17. ENEFGY STSTEN CONTFULLER

A. E1 MIECELEHEUE

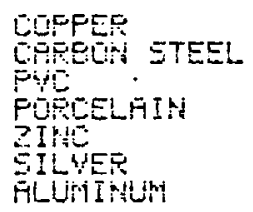

1554. 5

198. 5

5.

ii.

$-9$ 


\section{FOOTNOTES}

12. Energy Collector

All material items have been adjusted for the $16 \mathrm{ft} \times 210 \mathrm{ft}$ pond dimensions and the number of ponds reduced from 36 to 26.

Asphalt paving was eliminated. Unistreet anchor street in curbing was replaced with $1 / 2$ in. machine bolts put in the concrete curbing.

Glazing bows were estimated on the new pond dimensions.

12.08 - Density of foam rubber was estimated.

13.02 - Height of pipe stands was estimated from description.

13.07 - The amount of bronze in cast iron valves was estimated on information obtained from valve manufacturers.

The amount of copper in the valve actuators was estimated on information obtained from the manufacturer.

13.08 - The amount of copper, tronze and steel in pumps and motors was estimated on information obtained from the manufacturers.

13.10 - The amount of concrete and steel in the pumping station foundation was estimated.

17. Energy System Controllers

The amount of each material was estimated on information obtained from measuring and weighing similar existing equipment. 
$\stackrel{P}{\dot{\omega}}$
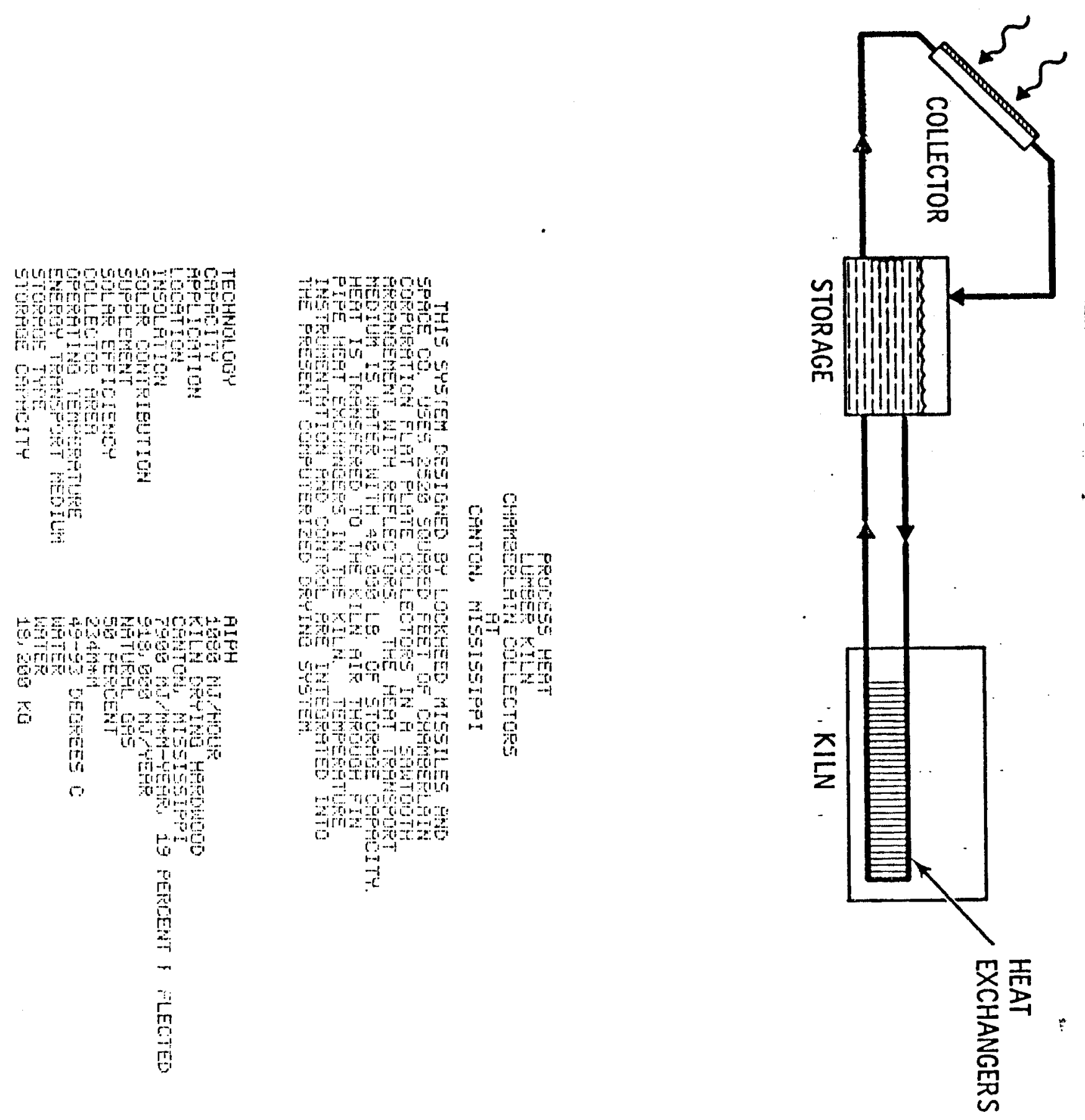

कE merima if -1 menge 종

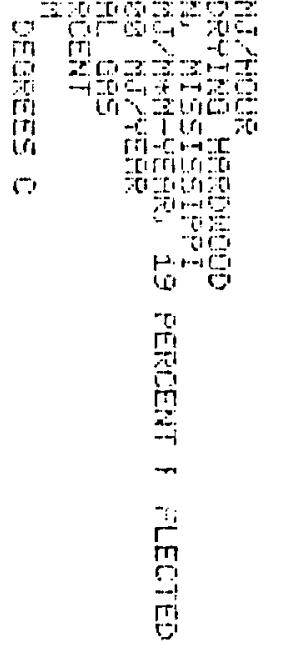




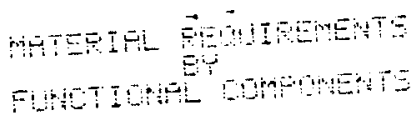

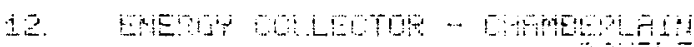

$$
\text { UUE }
$$

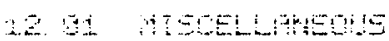

GHE 9 IEE.

$1 \div 9$

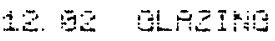

GDE IDE GISES

$47-9$

4. 02 MEDEE

HEO STE

CPUI I

MITELL

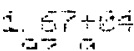

is

AD HOLETH

$\cdots$

50.5

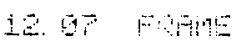

atiming

OHE

70

$=0$

a. 3

EDT EUEEE

12

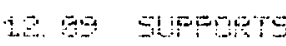

\section{EqT}

CPET STEE

Eitifining

Grif

Pontite

i. $7+9$

$-7 \times 0$

$2+$

$7+\frac{1}{1}$

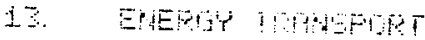

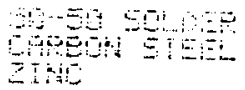

$\because$

1.

Hese

GEDA STE

52

$2-2$

85

izo

SEETMHE

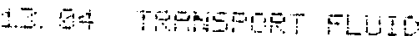

WISEF

2120

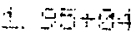

J. 97 VLVE

GESE TIN EPCHZE

1900 PIns

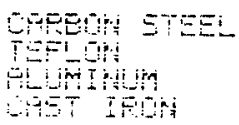

23.

8

20

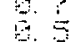

8.9 
14. EHEFIJ' COLRSEPSION

14. a1 MISCELLAEOUS GTEFS HRO HARTES BIREO STEEL 15. 5

14. GI MEAT EULHAROEF

15. EREFEIS STORAIGE

15. 91 MIECELLFREOJS

FOAREO THEULATIOH UEETHERE

81. 5

15. GE STLPATE TARHE

17. EMERI'Y SYSTEN CONTFILLER

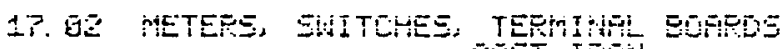
CTET IPTH LEETEO TIK EEQR⿴囗十 GOA LIVIE HLAES Geon $=$

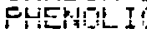

$5 I$ IICE

NTCKE

Filualing

Fut

COFFE

5. $\frac{9}{1}$

6.

s?.

i.

E. 7

$\frac{1}{5}$

7

12. 


\section{FOOTNOTES}

10. Estimates based upon document by S.J. Robertson and P.O. Mc Cormick, Solar Industrial Process Heat for Kiln Drying Lumber, Final Report Phase I, LMSC-HREC TR D497234, March 30, 1977.

13. ENERGY COLLECTOR

12.03 - Used Plating Thickness from Handbook

12.09 - Cadmium plate estimated on basis of $1 / 2 \mathrm{in}^{2} /$ fastener coated 0.0025 in. thick.

13. ENERGY TRANSPORT

All items taken from bill of material.

13.01 - Assumed 6' - 0" spacing.

13.01 - Assumed 2 in. wire solder used per average joint.

13.02 - Handbook weights used on al1 pipe, tubing and fittings.

13.08 - Material weights estimated on basis of motor and pump unit weight.

14. ENERGY CONVERSION

14.01 - Estimated.

17. ENERGY SYSTEM CONTROLLER

17.02 - Materials estimated from component parts. 

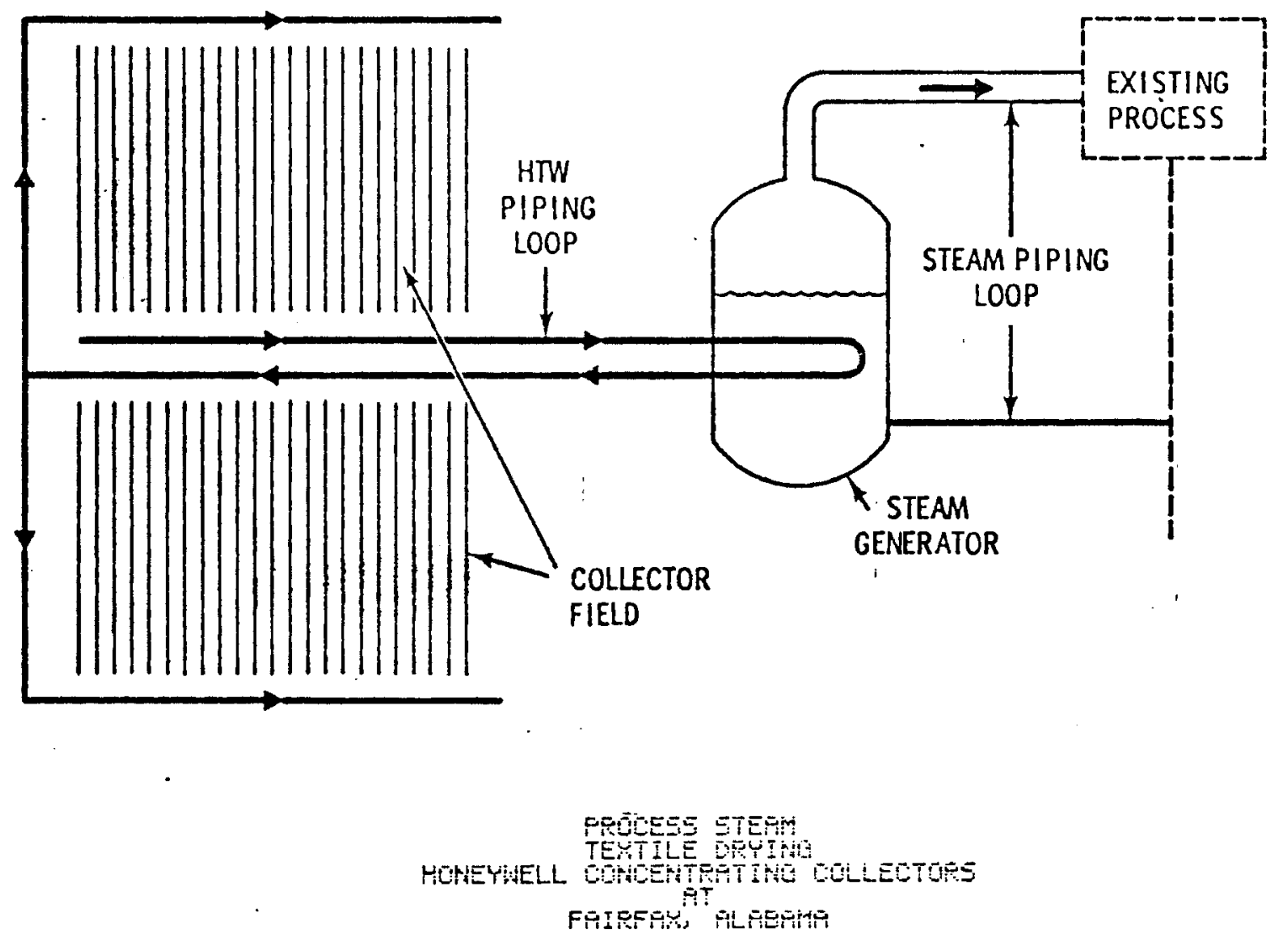

THIS SYSTEM DESTGHED EY HORECHELL IRGOEPOEATEO

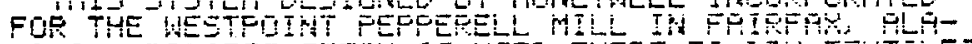

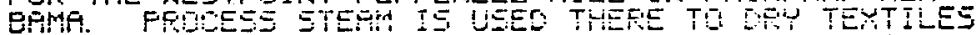

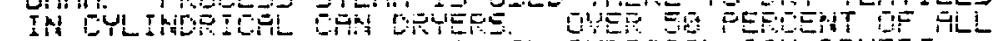

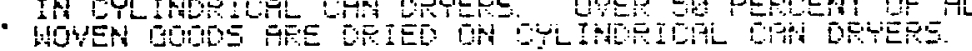

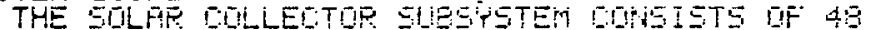
Coeso

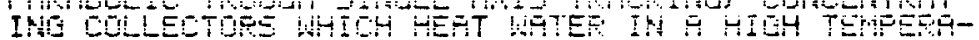
TeE

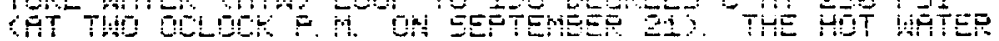
Eorm Tue ol

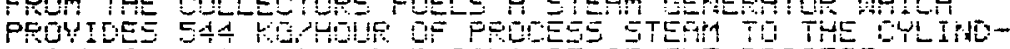

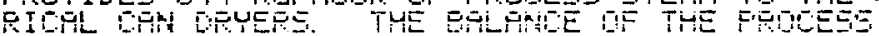

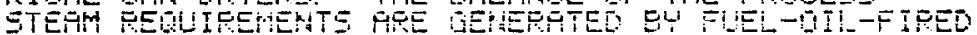

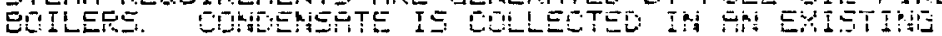

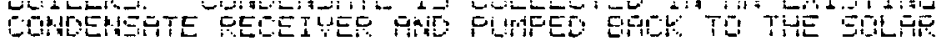

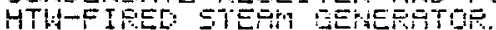

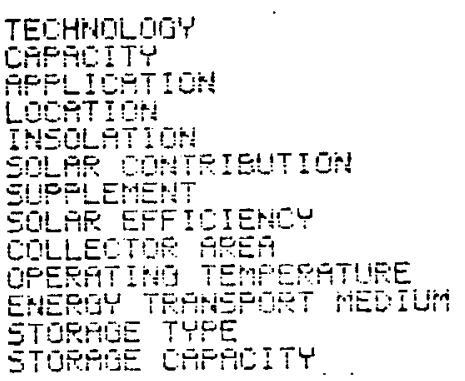

AIFH

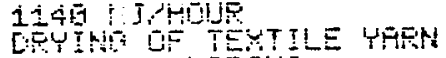

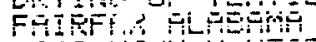
$4=8$ ond

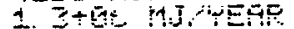
Fi_t 4OEFIEAT $7=3+19$ i Pilide

Mijhie 


\begin{tabular}{|c|c|c|c|c|c|c|c|c|c|}
\hline 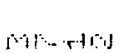 & +4000 & 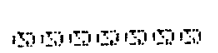 & जाTiक्ता & 250 & min & $\sin$ & 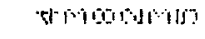 & a & 政 \\
\hline (1) & في & की & $\operatorname{lin}_{\rightarrow+1}$ & and & 象19 & ming & 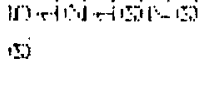 & $\frac{\pi}{5}$ & i \\
\hline
\end{tabular}
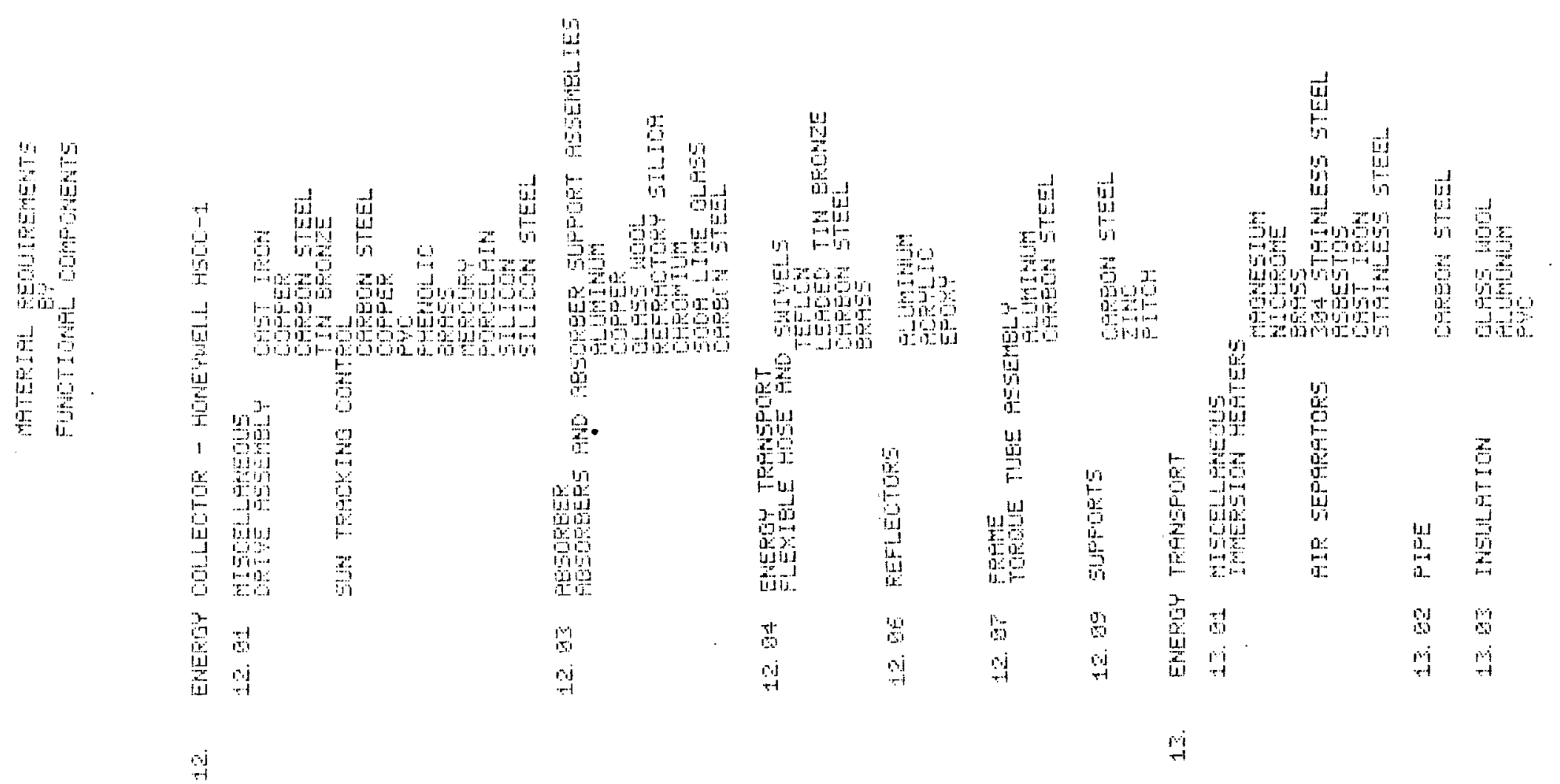


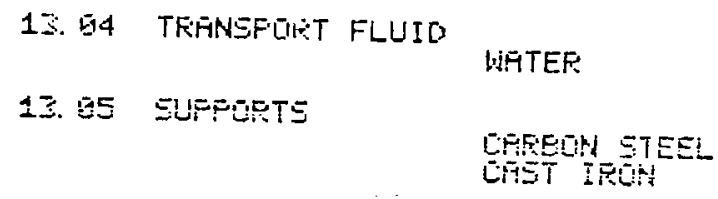

$164 \div$

13. BP VHLUES

FLUMIPHAM

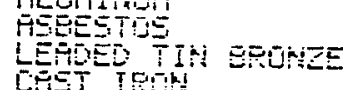

LET TCT Thl

41E STHRTESS STEEL

IE ETAIHLESS STEEL

CAEEON STEEL

ECFE

STAI HESS STEEL

1. 6

13. 95 FUMFS

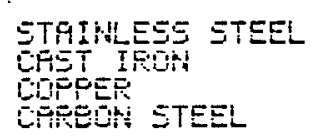

6. 4

2.9

7.5

i. 1

3

19

2

ต. 1

1ำ.

E5.

1i.

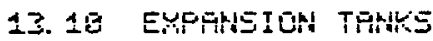

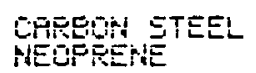

14. ENIERTEY LUNVEFSION

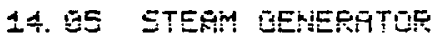

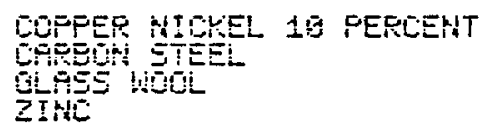

17. ENERE' STSTEM CONTFOLLER

象象

40

4. 5

17. EE METEPE, SHITCHES, RELPYS,

TERMTHEL EUREOS ETEOE

CFEATI STEEL

PHERTI TS

STHTHLESS STEEL

1.5

19.

sic.

17. GE SUPFIRTS - CAEIRETS

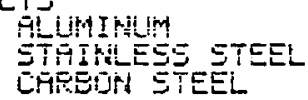

36. $\overline{6}$ 761. 5

22. FLART UTILITIES

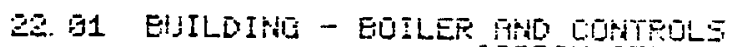

CFEOU⿴囗十⺝

FICEFOL

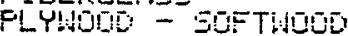

1506

793

4 ㄴ.

22. G2 EREEGCHCY GENEFATOE

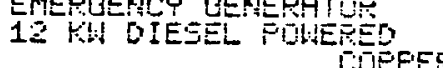

Aluth ind

COST IVOTH

CAEEOH JTEEL

45.4
-4.5
-45.5
31.5 


\section{FOOTNOTES}

10. Data are based on report 0R0/5124-77/1, March, 1977.

12.04 - Tefion hose assumed.

12.06 - Epoxy adhesive assumed.

17. Energy system control requirements assumed to be $1 / 2$ of the MIT-LL and UNL photovoltaic system at Mead, Nebraska. 
ENERGY CONTRIBUTION CALCULATIONS

The details of all energy contribution calculations are given in Tables B.1, B.2, B.3, and B.4 which follow. 
TABLE B.1. Details of Energy Contribution Calculations

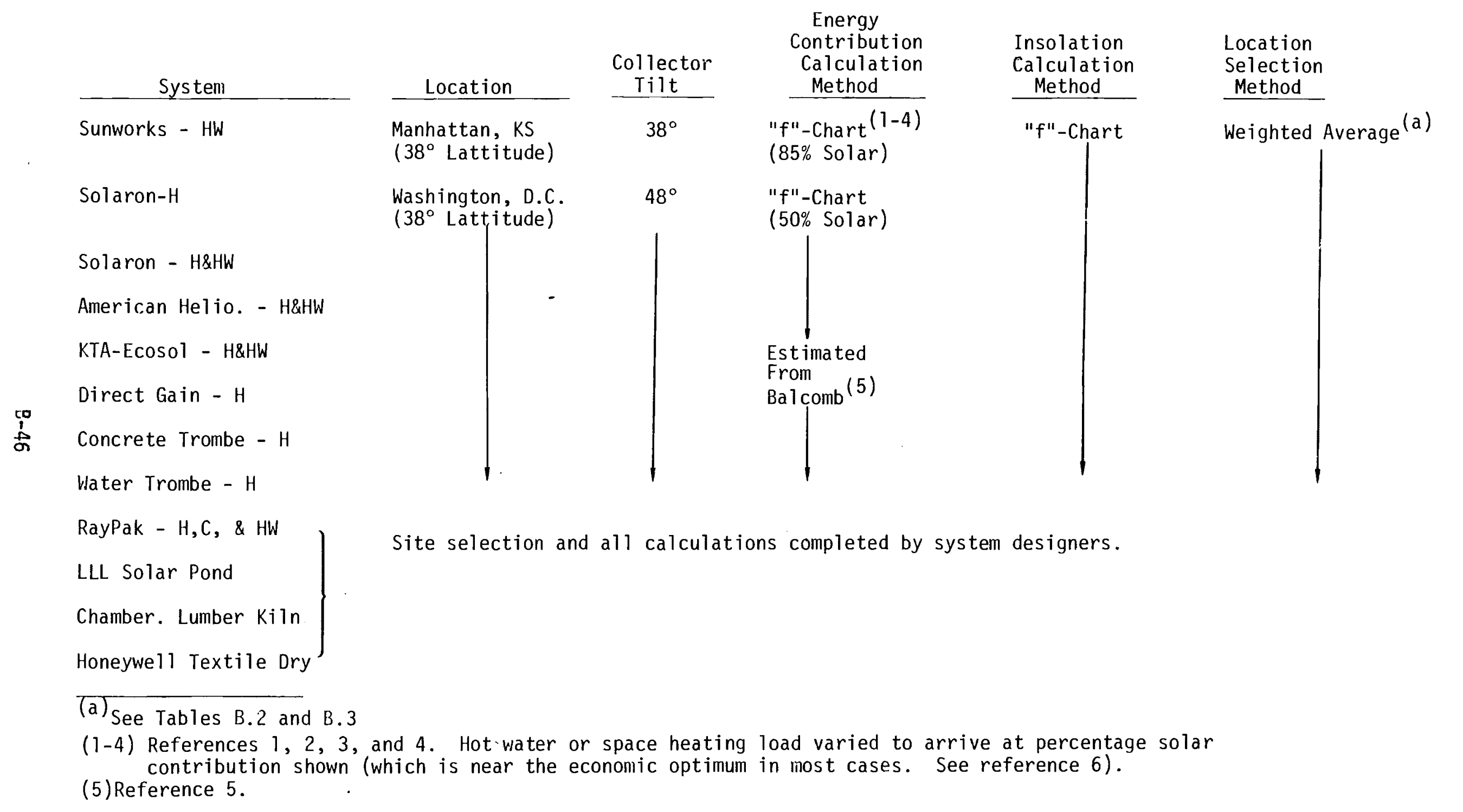


TABLE B.2. Calculation of Weighted Average Solar Contribution From $6.9 \mathrm{~m}^{2}$ Sunworks DHW System(a)

State and Representative City $(6)(b)$

CA-Los Angeles

FL-Miami

NY-I thaca

NJ- New York City

AZ-Phoenix

MD-Washington, DC

NV-Las Vegas

DL-Washington, DC

TOTAL
Projected New

Homes Using

Electric DHW

1977-1985(6)

(1000)

$200+$

$200+$

$100-199$

$100-199$

50-99

$50-99$

$1-49$

$1-49$

\begin{tabular}{c}
$\begin{array}{c}\text { Assumed } \\
\text { Number of } \\
\text { Homes With } \\
\text { Solar DHW } \\
(1000)\end{array}$ \\
\hline 250 \\
250 \\
150 \\
150 \\
75 \\
75 \\
25 \\
25 \\
\hline 1,000
\end{tabular}

Solar Contribution per Home (1-4)

(At $85 \%$ Solar DHW)

(GJ/yr)

18.5

19.0

8.42

9.85

23.9

11.5

23.1

11.5
State Yearly Solar Contribution

From Solar DHW $\left(10^{3} \mathrm{GJ}\right)$

4626

4750

1263

1478

1794

859

578

$15, \overline{634}$

(a) Weighted Average Contribution $=\frac{15,634}{1,000}=15.63 \mathrm{GJ} / \mathrm{yr}$.

Representative Location Selected-Manhattan, $\mathrm{KS}=14.38 \mathrm{GJ} / \mathrm{yr}$ (15.63-14.38=1.25 GJ or $8 \%$ Allowance for System Thermal Losses)

(b) States listed are those where solar DHW is economically feasible in competition with electric resistance on a 10-yr life cycle cost basis without government incentives. $0 i l$ and gas are more economical on 10-yr life cycle basis without government incentives. Some states were represented by cities, outside of the state that have similar weather conditions. 
TABLE B.3. Calculation of Weighted Average Solar Contribution From $25.4 \mathrm{~m}^{2}$ Solaron Space Heating System(a)

\begin{tabular}{|c|c|c|}
\hline $\begin{array}{c}\text { State and } \\
\text { Representative } \\
\text { City } 6)(b) \\
\end{array}$ & $\begin{array}{c}\text { Projected New } \\
\text { Homes Using } \\
\text { Electric Space } \\
1977-1985)(6) \\
(1000) \\
\end{array}$ & $\begin{array}{l}\text { Assumed } \\
\text { Number of } \\
\text { Homes With } \\
\text { Solar Heat ing } \\
(1000) \\
\end{array}$ \\
\hline NY-I thaca & $100-199$ & 150 \\
\hline MD-Washington, $D C$ & $100-199$ & 150 \\
\hline MA-Boston & $50-99$ & 75 \\
\hline NJ-New York City & $50-99$ & 75 \\
\hline CT-Boston & $1-49$ & 25 \\
\hline RI-Newport & $1-49$ & 25 \\
\hline VT-Mt. Weather & $1-49$ & 25 \\
\hline NH-Mt. Weather & $1-49$ & 25 \\
\hline ME-Portland & $1-49$ & 25 \\
\hline WI-Madi son & $1-49$ & 25 \\
\hline MN-St. Cloud & $1-49$ & 25 \\
\hline ND-Bismark & $1-49$ & 25 \\
\hline SD-Rapid City & $1-49$ & 25 \\
\hline C0-Boulder & $1-49$ & 25 \\
\hline NM-Al buquerque & $1-49$ & 25 \\
\hline TOTAL & & $\overline{725}$ \\
\hline
\end{tabular}

\begin{tabular}{|c|c|}
\hline $\begin{array}{c}\text { Solar } \\
\text { Contribution } \\
\text { Per Home }(1-4) \\
\text { (At } 50 \% \text { Solar) } \\
(\mathrm{GJ} / \mathrm{yr}) \\
\end{array}$ & $\begin{array}{l}\text { Yearly Solar } \\
\text { Contribution } \\
\text { From Solar } \\
\text { Space Heat } \\
\left(-10^{3} \text { GJ }\right) \\
\end{array}$ \\
\hline 22.9 & 3437 \\
\hline 27.4 & 4108 \\
\hline 26.4 & 1978 \\
\hline 22.7 & 1701 \\
\hline 26.4 & 659 \\
\hline 35.7 & 893 \\
\hline 35.3 & 881 \\
\hline 35.3 & 881 \\
\hline 41.7 & 1043 \\
\hline 35.0 & 876 \\
\hline 41.9 & 1047 \\
\hline 46.38 & 1159 \\
\hline 53.7 & 1343 \\
\hline 48.1 & 1203 \\
\hline 56.7 & 1417 \\
\hline & $\overline{22,626}$ \\
\hline
\end{tabular}

(a) Weighted Average Contribution $=\frac{22,626}{725}=31.2 \mathrm{GJ} / \mathrm{yr}$.

Representative Location - Washington $D C=27.4 \mathrm{GJ} / \mathrm{yr}$.

$(31.2-27.4=3.8 \mathrm{GJ}$ or $11 \%$ allowance for system thermal losses)

(b) Cities where solar space heat economically competitive with electric resistance on 20-yr life cycle cost basis without government incentives. $0 i 1$ and gas are more economical on 10-yr life cycle basis without government incentives. Some states were represented by cities, outside of the state that have similar weather conditions. 
TABLE B.4. Solar Contribution From 500 Million $\mathrm{m}^{2}$ of Collector

SHACOB Systems

Sunworks Res HW

Solaron - Res HT

Solaron - Res HT + HW

Amer Heliothermal $\mathrm{H}+\mathrm{HW}$

KTA and ECOSOL Heat Pump System

RayPak - HT+COOL+HW

Trombe Wall Concrete

Trombe Wall Water

Direct Gain Masonry Wall

Mixed Case (Equal Portions of all

9 SHACOB Systems)

AIPH Systems

LLL Solar Pond

Chamberlain - Lumber Kiln

Honeywell Concentrating

Mixed Case (Equal Portions of all

3 AIPH Systems)
Solar Contribution Quads

0.9

0.5

0.7

0.8

1.0

1.0

0.2

0.2

0.4

0.64

1.5

1.9

0.8

1.4 


\section{APPENDIX B: REFERENCES}

1. Solar Collector System Engineering, Program ACSE 1. Scotch Programs Box 430734, Miami, FL.

2. S. A. Klein, W. A. Beckman, and J. A. Duffie, "A Design Procedure for Solar Heating Systems." Solar Energy, 18:113, 1976.

3. W. A. Beckman, J.A. Duffie, and S. A. Klein, "Applications of Solar Energy for Heating and Cooling a Building," Simulation of Solar Heating Systems. Chapter 9, ASHRAE, NY, 1976.

4. S. A. Klein, W. A. Beckman, and J. A. Duffie, A Design Procedure for Solar Air Heating Systems. 1976 ISES American Sect. Conf., Winnipeg, Manitoba, August 15-20, 1976 .

5. J. D. Balcomb, J. C. Hedstrom, R.D. McFarland, "Passive Solar Heating of Buildings," Workshop on Solar Energy Applications. Associated Universities, Inc., June 27-ju1y 31, 1977.

6. F. Roach, et a1., Prospects for Solar Energy: The Impact of the National Energy Plan. LA-7064-MS, Los Alamos Scientific Laboratory, Los Alamos, NM, December 1977. 
No. of Copies

\section{OFFSITE}

27 DOE Technical Information Center

10 Fred Koomanoff Space Power Systems Project Office Office of Energy Research

Department of Energy Washington, D.C. 20545

1 A. A. Churm COE Patent Division $9800 \mathrm{~S}$. Cass Avenue Argonne, Illinois

ONSITE

DOE Richland Operations office

I H. E. Ransom

61 Pacific Northwest Laboratory

R. L. Watts (48)

S. A. Smith

T. A. Nelson (2)

W. E. Gurwel1 (2)

C. H. Bloomster

Technical Information Files (5)

Publishing Coordination (2) 
